UNIVERSIDADE DE SÃO PAULO

FACULDADE DE FILOSOFIA LETRAS E CIÊNCIAS HUMANAS PROGRAMA DE PÓS-GRADUAÇÃO EM SOCIOLOGIA

\author{
Matheus Gato de Jesus
}

\title{
NEGRO, PORÉM REPUBLICANO: \\ INVESTIGAÇÕES SOBRE A TRAJETÓRIA INTELECTUAL DE RAULASTOLFO MARQUES (1876-1918)
}

São Paulo

2010 
UNIVERSIDADE DE SÃO PAULO

FACULDADE DE FILOSOFIA LETRAS E CIÊNCIAS HUMANAS

PROGRAMA DE PÓS-GRADUAÇÃO EM SOCIOLOGIA

Matheus Gato de Jesus

\section{NEGRO, PORÉM REPUBLICANO: \\ INVESTIGAÇÕES SOBRE A TRAJETÓRIA INTELECTUAL \\ DE RAULASTOLFO MARQUES (1876-1918)}

Dissertação apresentada ao Programa de Pósgraduação em Sociologia da Faculdade de Filosofia, Letras e Ciências Humanas da Universidade de São Paulo como requisito parcial para obtenção do título de Mestre em Sociologia.

Orientador: Prof Dr. Antonio Alfredo Sérgio Guimarães

São Paulo

2010 
A Josemar Antonio de Jesus, meu pai ( In Memoriam) 


\section{Agradecimentos}

A realização deste trabalho não seria possível sem o esforço de muitas pessoas. Deste modo quero manifestar minha gratidão a todas aquelas pessoas que de alguma forma contribuíram com essa pesquisa.

Em primeiro lugar, gostaria de agradecer ao professor Antonio Sérgio Guimarães pela dedicação, a confiança e o carinho a mim dispensados. A sua sensibilidade tem sido um guia seguro de aprendizado e crescimento pessoal. Sem o seu empenho na formação de jovens pesquisadores, este trabalho jamais teria sido realizado.

Agradeço aos professores Lilia Moritz Schwarcz, Omar Ribeiro Thomaz e Maria Alice Rezende de Carvalho pela leitura atenciosa que todos devotaram ao meu trabalho de qualificação. Suas críticas e sugestões foram preciosas para a condução desta investigação e a redação deste trabalho. Quero mencionar em especial a professora Lilia Moritz Schwarcz, que desde a disciplina Uma História da Antropologia no Brasil, ministrada no primeiro semestre de 2009, acompanha com interesse o desenvolvimento desta pesquisa.

Não poderia deixar de agradecer a professora Marcia Lima e o professor Kabengele Munanga pela receptividade e o afeto com que me acolheram na Universidade de São Paulo. O grupo de estudos e leituras coordenado pela professora Marcia Lima no primeiro semestre de 2008 constituiu para mim, não apenas momentos ricos de reflexão e análise, mas uma sociabilidade e solidariedade com amigos e colegas. Da mesma forma, a disciplina Teorias Sobre o Racismo e Discursos Anti-Racistas, ministrada pelo professora Kabengele Munanga, ultrapassou as barreiras do formalismo acadêmico e fortaleceu o profundo sentimento de admiração e respeito que nutro por ele desde que nos conhecemos pessoalmente em 2005 .

Dentre os apoios institucionais gostaria de agradecer ao CNPQ e à FAPESP que subsidiaram este trabalho. Sem a bolsa de estudos esta pesquisa não sairia do papel.

Ao COSEAS, cujo trabalho de assistência estudantil permitiu-me o ambiente ideal para o desenvolvimento desta pesquisa.

Não poderia deixar de agradecer às diversas agências de preservação documental que me auxiliaram neste trabalho. No Maranhão, quero destacar: a Biblioteca Pública Benedito Leite, a Casa de Cultura Josué Montello, a Academia Maranhense de Letras, a Biblioteca da Associação Comercial do Maranhão, o Arquivo Público do Estado do 
Maranhão. Quero agradecer em especial ao Centro de Cultura Negra do Maranhão que disponibilizou equipamentos eletrônicos para a consecução desta pesquisa.

Uma parte significativa deste trabalho ocorreu na cidade do Rio de Janeiro. Quero agradecer ao trabalho de preservação da história brasileira levado a cabo pela Fundação Biblioteca Nacional. Sem os seus inúmeros e preciosos arquivos, nossa memória estaria comprometida. Também agradeço a José Augusto Gonçalves, funcionário da Biblioteca Nacional, que se dispôs a localizar os volumes perdidos do Diário Oficial do Maranhão que ali existiam, com o único fito de meu ajudar, meus sinceros agradecimentos. Também sou muito grato à Academia Brasileira de Letras, pelas excelentes condições de trabalho que oferece aos pesquisadores.

Naquela cidade, realmente maravilhosa, contei com a ajuda de amigos muito queridos tais como Hélen, Vanuza, Alê, Aninha, Luena, Rogério e Gisele. Agradeço em especial ao amigo Uelinton Alves Farias, pesquisador experiente e amigo sincero, por sua inestimável ajuda para a realização deste trabalho.

No Maranhão, deixei amigos sinceros e muito queridos. Sou grato por toda essa saudade que vocês me deixaram. Jaílson, o grande irmão que a vida me deu, Glauber, Jussara, Carlão, Álvaro, Jorrimar, Sílvio, Rômulo, Nádia, Kátia, Kazal, a todos vocês, muito obrigado.

Em São Paulo, conquistei amigos queridos, Thiagão, Gel, Gabi, André, Danilo e Sidney.

A meus familiares, Vovô, Ozilha, Camila e Daniela, obrigado pelos momentos felizes no Jaraguá.

Quero agradecer ainda a Edilza Sotero, pela paciência, compreensão e pela lealdade.

A Dyl Pires, por uma cumplicidade de quase vinte anos.

Ao Alex Ratts, porque sabe o quanto é responsável por eu estar aqui.

À minha mãe, Lucia Gato, e à minha irmã, Bárbara, pela compreensão e carinho, apesar da solidão.

Seria um pecado não terminar este trabalho com uma linha dedicada a minha felicidade, Flávia Mateus Rios, por tudo que temos vivido juntos. Uma linha simples e terna, como as nossas alegrias, as mais cotidianas e secretas: Eu te amo. 


\section{SUMÁRIO}

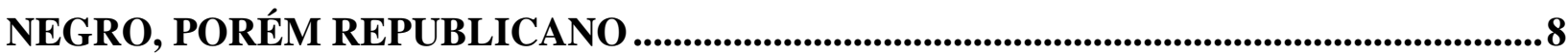

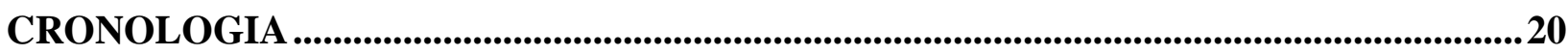

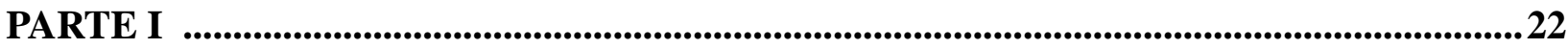

UM ILUSTRE DESCONHECIDO ............................................................................................23

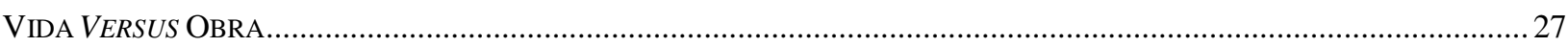

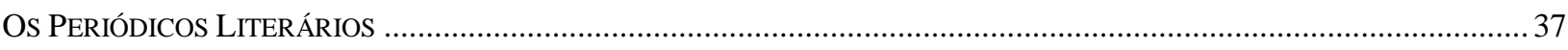

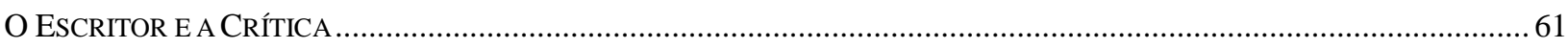

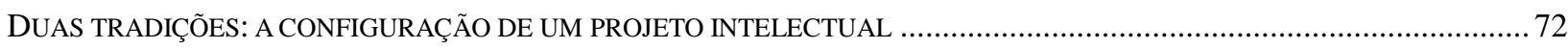

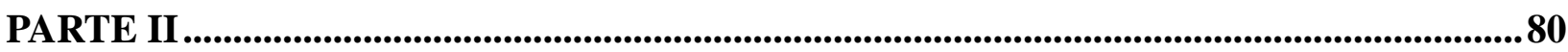

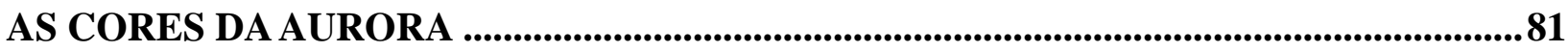

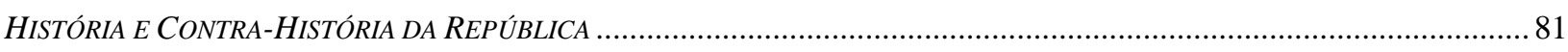

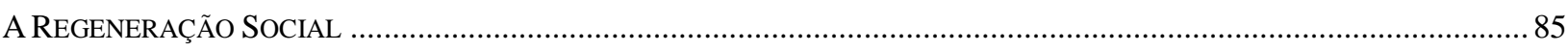

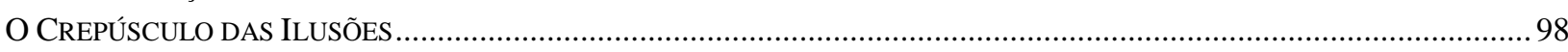

CONSIDERAÇÕES FINAIS..................................................................................................................119

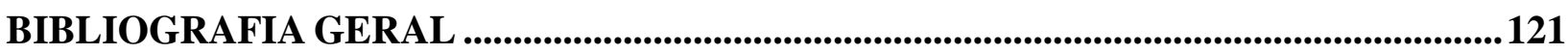

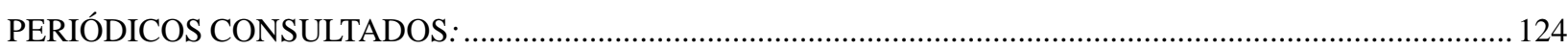

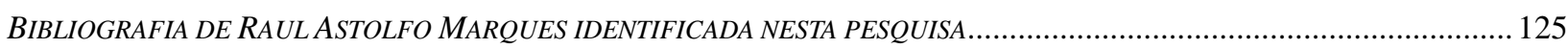

ANEXOS ..........................................................................................................................................130 
Resumo: O presente trabalho é uma investigação sobre a trajetória intelectual de Raul Astolfo Marques (1876-1918). Fruto da geração de ex-escravos nascida sobre a égide da Lei do Ventre Livre (1871) e as transformações que levaram ao fim do trabalho servil e a capitulação da monarquia, o escritor logrou grande expressão pública no Maranhão da República Velha e conta entre os fundadores da Academia Maranhense de Letras. Na primeira parte desta dissertação intitulada Um Ilustre Desconhecido, tentamos compor a trajetória intelectual do escritor a partir de uma sociologia crítica das fontes na qual o autor é representado. $\mathrm{Na}$ segunda, As Cores da Aurora: história e contra-história da república, focaliza-se exclusivamente o romance A Nova Aurora no qual o autor expõe literariamente os significados da transformação política de novembro de 1889 para o povo brasileiro.

Palavras-chave: Raul Astolfo Marques, Literatura Maranhense. Intelectuais Negros, República.

Abstract: This research analyzes the intellectual trajectory of Raul Astolfo Marques (18761918). Marques was part of a generation of former-slaves born after the Free Womb Law (1871). This generation watched the work slave end and the monarchy surrender. This writer had great public expression in Maranhão at that time in the First Republic (1889-1930) and he is also one of the Academia Maranhense de Letras founders. In the first part of this dissertation Um Ilustre Desconhecido, we try to compose the intellectual trajectory of Marques, starting from a critical sociology of the sources in which the author is represented. In the second part, As Cores da Aurora: história e contra-história da república, the centers is A Nova Aurora romance where the author presents literarily the meanings of the policy transformation in November 1889 for the Brazilian people.

Keywords: Raul Astolfo Marques, Literature from Maranhão, Black Intelectuals, Republic. 


\section{Negro, Porém Republicano}

Pouco menos de dois anos antes de sua morte prematura em 28 de maio de 1918, o escritor Raul Astolfo Marques (1876-1918) publicou em O Jornal, diário de São Luís do Maranhão, um divertido conto com o título Reis Republicanos. O tema era a agonia do popular e festeiro Daniel, morador do bairro Curupira, às voltas com a construção de seu famoso presépio no natal de 25 de dezembro de 1889. A proclamação da república no mês anterior o pegara de surpresa. A violência campeava nos arrabaldes da cidade. Qualquer demonstração de apego à coroa era punida com severidade pelas autoridades republicanas. Daniel sentira-se acuado.

\footnotetext{
$\mathrm{Na}$ sua persistente faina de exibir, em cada natal, um presépio cada vez mais lindo e atraente estava a vacilar sobre a instalação dos santos Reis Magos, naquele ano, no seu ORIENTAL, pomposa e mística denominação dada ao mesmo presépio.

Metera-se na telha do ardoroso devoto do Deus Menino que o tenente Queirós, o delegado terrorista, não consentiria em que os três soberanos, parte integrante do Oriental, se mostrassem neste. Mas, avaliava, seria uma lacuna por demais sensível a ausência, do presépio, daquelas belíssimas maravilhas da escultura portuguesa (...). (O Jornal, 24 de Dezembro de 1916).
}

Daniel consultara "deus e o mundo" a fim de tentar resolver o problema. Era uma verdadeira enrascada. $\mathrm{O}$ seu orgulhoso e reconhecido zelo pelas festas natalinas poderiam pôlo frente a frente com o "delegado terrorista" que comandava a polícia instituída pelo golpe político. "Ficaria satisfeito se lhe deparasse um ensejo de fácil conciliação dos três régios visitantes do Salvador com os das autoridades republicanas cá da terra”. Sentia-se verdadeiramente cercado pelos temíveis poderes dos céus e do governo. Ele mesmo nem se opunha ao novo regime, mas não podia abandonar a tradição. Os conselhos dos amigos eram os mais contraditórios e o religioso festeiro preferiu esperar o momento mais oportuno para decidir o caso.

Foi com tristeza que no dia 25 de dezembro se viu constrangido, em plena solenidade de abertura do Oriental, a informar a todos as razões da ausência dos três monarcas do presépio: "Acompanhava a opinião do país que consentia na deportação da família bragantina, e eliminara também os Santos Reis, do ORIENTAL, naquele ano de advento da República”. O discurso não produziu o desânimo esperado. Quando a orquestra soou os primeiros acordes todo o povo da Curupira se pôs a dançar e celebrar aquele que era um dos mais belos e tradicionais presépios da cidade. Entretanto, a alma de Daniel se vira inquieta. Nem mesmo o fato de ter contado com a mesma demonstração de afeto e carinho de 
seus amigos e vizinhos, quando se viu compelido a dar a mesma explicação no dia de Ano Bom, o demovera de tentar dar uma solução ao problema mais condizente com sua fé no menino Jesus.

Logo, os freqüentadores mais assíduos do presépio souberam que na festa de Véspera de Reis haveria uma surpresa. O boato aguçou ainda mais a curiosidade dos moradores das cercanias, que antes da hora marcada para a nova abertura do Oriental garantiam seus lugares. Ao badalar das dez horas desceram-se as cortinas:

\footnotetext{
Junto ao escalpelo que se erguia o Deus Menino, todo rechonchudo e corado, envolto na sua alva vestimenta de cetim, aureamente lantejoulada, estavam genuflexas as figuras de Gaspar, Belchior e Balthazar, ostentando nas frontes, rubros e elegantes barretes frígios, em substituições as argênteas coroas, que lhas cingiam, nos anos precedentes.

Era que o Daniel tomara a suprema resolução de restituir aos Santos Reis o seu lugar no famoso presépio. Fizera-o, porém, republicanizando-os, para o gaudio dos dançantes republicanos e desespero dos presepistas monárquicos.

E desse agrado a uns e desagrado a outros, estabelecendo a equidade, o atilado Daniel, na emoção que o sufocava, julgou-se desagravado perante os três santos soberanos e bondosos, nos céus, e os homens maldizentes, na terra (O Jornal, 24 de Dezembro de 1916).
}

O conto Reis Republicanos expressa, com riqueza de detalhes, as principais características que marcaram a sensibilidade literária de Astolfo Marques ao longo de sua curta carreira. $\mathrm{O}$ texto atravessa a vida cotidiana dos bairros pobres da capital maranhense, a devoção católica, as dificuldades e alegrias do povo, as festas populares regionais e uma verdadeira obsessão temática: a queda da Monarquia imperial e o advento da República.

Uma parte significativa da literatura produzida pelo escritor negro maranhense poderia ser entendida como uma tentativa sistemática de interpretar os significados da transformação política de 1889 para o povo. O tema comparece ao longo de toda a sua trajetória intelectual em contos como Abnegação (1902), A Última Sessão (1903), O Discurso do Fabrício (1903), A Opinião da Euzébia (1904), De Corôa e Barrete (1908), além do próprio Reis Republicanos (1916). Resta dizer que A Nova Aurora (1913), seu único romance, é inteiramente dedicado à descrição dos primeiros meses de implantação do regime republicano. O devoto Daniel não é, portanto, um caso único. Ele pertence a uma vasta galeria de personagens embaraçadas com o quinze de novembro. Entretanto, sobreleva-se entre aquelas que lograram uma solução "razoável" para o problema.

É interessante notar que, aparentemente, o dilema do festeiro em colocar ou não os três reis magos não possui inicialmente qualquer conotação política. O seu impasse é como manter intocada a tradição popular das festas natalinas mediante as perseguições da polícia republicana, já que fazia quinze anos que organizava seu presépio. Ele mesmo dizia “acompanhar a opinião do país” e achou por bem conduzir os áulicos para exílio, só que não 
podia abalar sua fé. A dificuldade da situação política o força por duas vezes a retirar os régios do presépio e afirmar em alto e bom som perante a assistência sua fidelidade à república. Mas no final ele encontra uma saída: manteria Gaspar, Belchior e Balthazar, como pedia o costume religioso, porém retiraria a coroa, símbolo máximo do poder monárquico, substituindo-a pelo barrete frígio republicano.

Astolfo Marques sugere, através da divertida manipulação dos símbolos de poder realizada por sua personagem, as ambivalências implícitas nas transformações políticas que marcaram o surgimento do Brasil moderno. A oposição inconciliável entre o barrete e a coroa expressa a distância entre a república e o povo. Toda a pompa da realeza que desce aos inúmeros presépios dos bairros pobres da cidade vem "bondosa e soberana" dos céus e não dos "homens maldizentes da terra". Ao contrário do que poderiam pensar as autoridades republicanas, não se tratava de uma manifestação explícita em favor da monarquia, mas da livre expressão do imaginário popular. Neste sentido, a lacuna que salta aos olhos de todos os visitantes do Oriental na festa do Deus Menino em dezembro de 1889 é o anúncio de sua própria exclusão social e política no regime republicano.

Entretanto, para o autor, caberia à intensa criatividade da cultura popular, a sabedoria da gente miúda brasileira ali exprimida entre arbitrariedade política e a privação das condições mínimas de existência, arranjar um modo de inventar a liberdade nos interstícios da ordem autoritária e manter a esperança de que "com jeito" as coisas podem melhorar. Marques nos conduz a uma espécie de sincretismo político, "a equidade", diria ele, capaz de acomodar as contradições sociais que "sufocam a emoção" da massa negra e mestiça. A utopia de melhorar a vida subsiste num processo de ajuste em que os próprios símbolos da opressão são incorporados, mas de modo a obedecer a lógica simbólica tradicionalmente arraigada. Daniel é um grande bricoleur. Mesmo com barrete frígio a realeza está presente. A alternativa dos dominados, para manter sua autonomia cultural e esperanças políticas no novo regime, seria exprimir seus próprios desejos lançando mão dos códigos políticos agora dominantes.

É precisamente todo esse esforço dialético, que tem sido necessário à conquista da felicidade na moderna sociedade brasileira, que desejo objetivar na frase polêmica Negro, Porém Republicano. Não pretendo inferir qualquer contradição formal entre ser negro e republicano, mas iluminar suas controvérsias. Neste incômodo "porém" reside o fundo de emoção sufocada, desacertos, bricolagens, enfim, toda a engrenagem de pensamento selvagem que o acaso histórico tem de atravessar para sedimentar-se numa cultura. Se nos dias de hoje, mediante as reivindicações do movimento negro por igualdade de oportunidades na 
sociedade brasileira, justificadas como supremo dever da carta democrática constitucional (1988), ser negro e republicano pareça uma posição mais do que "natural", no passado, a confiar em Astolfo, podia estragar o natal de muita gente boa.

Na crônica A Última Sessão, publicada em 1903, no boletim do grêmio literário Oficina dos Novos, o próprio autor esclarece "os seus poréns" em relação aos significados sociais da proclamação da República. Segue o texto na íntegra:

$\mathrm{Na}$ estação telegráfica e numa das janelas da redação d’O Globo havia sido afixado um boletim anunciando a organização, no Rio, do governo provisório bem como as medidas tomadas a respeito do embarque para Europa, no vapor Alagoas, do monarca recém destronado.

A câmara municipal, composta de conservadores, na sua maioria, recebera a notícia como se fosse um maná vindo do céu. Excelsamente transportados de alegria, os seus membros, pouco se importavam que se lhes exprobassem de não confraternizarem com os líderes ajudando-os a sustentar o trono baqueante. Menos ainda ligavam aos que lhes acusavam de não ter fé monárquica, pois, consideravam: não fora essa monarquia, agora por terra, que promovera a libertação dos cativos, sem indenização? Era azado o momento da desforra, e a ninguém mais do que aos vereadores, dizia um destes, compete como representante dos municipais, soltar o grito de adesão.

E opulentamente trajados, dirigiram-se a casa do vereador presidente, que, ouvindo-os religiosamente, concordou com os seus considerandos e fez convocar incontinente uma sessão extraordinária.

Reunidos os o gestores dos destinos municipais, depois de serem sugeridos mil projetos e idéias, foi resolvido que a câmara ficasse em sessão permanente 'aguardando ordem do governo provisório', passando a este um telegrama de congratulações em que cientificava o deliberado. Isto feito, retiraram-se o vereadores aos seus penates, ficando dois beleguins, prontos a primeira voz, substituindo-os na permanência.

Entardecera já. A cidade apresentava um aspecto bélico. Havia um presidente que não presidia, pois abandonando um posto de honra, abrigara-se na casa do chefe do partido em cujo expirara a monarquia; no largo do Carmo, trepado no Pelourinho, um orador concitava os magotes de monarquistas e curiosos que se revestisse da precisa calma para aguardar os acontecimentos; no quartel da tropa de linha tromitoava o sinal de reunir e logo depois o de avançar para o globo, donde haviam pedido garantias a fim de evitar o ataque do populacho desenfreado; um exdeputado geral, conservador, colocara-se (e fora o único) ao lado de liberais que queriam dar cabo da vida dos redatores do jornal da ladeira do Viramundo. Nesta, já a aglomeração fervilhava. Numa atitude guerreira os motineiros atiravam chufas aos jornalistas 'sitiados`. E, a proporção que se ia avolumando a massa, crescia as vaias e as ameaças. Chegada a força foi recebida a pedradas. Os soldados, então, despediram flamejantemente sobre os 'reivindicadores do trono` umas dezenas de baladas comblain, que zunindo entre os atacantes, os dispersou produzindo a morte em cinco, ferindo uns vinte, que passaram a posteridade como vítimas da abnegação por Isabel, a Redentora, e deram motivo ao Maranhão ser considerado 'a única província heróica que resistiu a implantação do novo regime.

Estabelecera-se a calma sendo já a noite alta. No dia seguinte, logo ao amanhecer, um telegrama vai ter a câmara municipal. Os beleguins correram presurosamente a chamar a seus postos os vereadores neo-republicanos, que no acharam reunidos todos com exceção de um único que estava no interior. Para sessão ordinária não se reuniriam com tamanha presteza. Confortavelmente instalados nas suas poltronas, ao troar do tímpano, apresentavam na sua fisionomia uma atitude magestosa. E quem sabe se nos cérebros daqueles depositários dos poderes municipais a idéia da palavra 'república não se lhes apresentasse como sendo todos eles 'majestade'!

$\mathrm{E}$ foi na antevisão de seguirem dali para o palácio governamental, então abandonado, que o presidente, tendo a pairar suspenso sobre a sua encanecida cabeça, ricamente emuldurado, um quadro de D. Pedro II, disse em voz alta e sonora: - Está reaberta a sessão! Em seguida, com um sorriso de satisfação, puxou do bolso o telegrama recebido, fechado ainda tal qual lhe entregaram o beleguim.

- Aqui temos a resposta, senhores; virá provavelmente seguida de altas e importantíssimas ordens, que, espero, todos cumpriremos de bom grado. 
E, preparando-se para ler o despacho como se fosse um evangelho, cavalgou a luneta sobre o aquilino nariz e abriu-o auspiciosamente. Os vereadores olhavam sofregamente para aquele papelzinho, em que, contavam, viria escrita a palavra de ordem, isto é, a palavra de ordem, isto é, a menção ao poder dos conservadores, metamorfoseados em republicanos da "gema". O presidente, com voz trêmula, procedeu a leitura do papelucho que fizera palpitar ansiosamente tanto corações. Dizia:

- Rosário, 17 de novembro de 1889.

\section{CAMARA MUNICIPAL}

S. LUIZ

QUE HÁ DE NOVO?

\section{Ferreira Moura}

Era o vereador ausente.

E foi a última que os vereadores monárquicos fizeram. Nesse mesmo dia a câmara foi dissolvida, e o telegrama quem o recebeu foi já a Intendência nomeada para substituir a agremiação conservadora.

A presente crônica é o único texto antes de A Nova Aurora no qual o autor articula uma visão propriamente histórica do processo que desencadeou no fim do segundo reinado. Em linguagem menos cifrada que Reis Republicanos, com ironia e laivos de intempestividade raros em sua obra, o então jovem Raul expõe de maneira direta sua crítica às bases políticas de adesão ao novo regime. Em Marques, a república é concretamente, para usar uma frase famosa, uma “idéia fora do lugar". Quem saberá ao certo se para os republicanos de ocasião, acossados pela abolição na câmara de vereadores de São Luís, "a idéia de república não se lhes apresentasse como sendo todos eles majestade”. Neste sentido, a principal contradição do quinze de novembro é que seus defensores de primeiríssima hora visavam conquistar por intermédio do golpe político o "poder pessoal", que a república deveria alijar em nome da cidadania.

O próprio perfil político daqueles que deveriam ser a vanguarda do progresso social era formado majoritariamente por elementos ligados ao partido conservador, quisto de ex-senhores raivosos, julgando-se traídos pelo governo monárquico nos seus direitos de propriedade privada devido à ausência da prometida indenização de suas peças humanas. A inautenticidade da posição dos "conservadores metamorfoseados em republicados da gema" também é assinalada pelo seu notório descaso com a coisa pública: não fossem as virtuais vantagens do evento em curso, "para uma sessão ordinária não se reuniriam com tamanha presteza".

O fato desses "neo-republicanos" serem risivelmente destituídos do poder no dia seguinte em nome do governo que receberam como um "maná vindo dos céus" só reforça, nas tintas carregadas de desprezo com que o escritor os caracteriza, o quadro de alienação dos políticos maranhenses. Para Astolfo Marques, enquanto o povo foi para as ruas lutar em prol da causa monárquica às portas do principal jornal republicano da cidade, as elites dirigentes 
provincianas assistiram à queda do império bestializadas. "Havia um presidente que não presidia, pois, abandonado o posto de honra, abrigara-se na casa do chefe do partido onde expirara a monarquia".

Nessa "lavagem de mãos" do poder público reside uma das principais razões para o "clima bélico" instalado dia 17 de novembro entre os jornalistas republicanos do diário $O$ Globo e os "magotes" monarquistas de ex-escravos na ladeira do Vira Mundo. Os mortos e feridos da multidão são expressão brutal da exclusão social e política armada a reboque da nova ordem. Esta talvez tenha sido a revolta popular que mais impressionou Astolfo Marques ao longo de toda sua vida. É provável que ele possa ter sido uma testemunha ocular do acontecido. Se não, viveu o clima de perseguição perpetrado pelas autoridades republicanas com o fito de conter maiores protestos. As menções ao "delegado terrorista" em Reis Republicanos me parecem uma alusão à experiência coletiva de medo partilhada pelo escritor, na época, com apenas treze anos de idade.

De qualquer modo, diferente de uma parte significativa da população negra oprimida pelas políticas republicanas de controle social, Astolfo Marques não entreviu na forma de governo em si mesma, as causas dos problemas que afetam a sociedade brasileira. Ele apontou, tendo mira o caso maranhense, as condições econômicas e políticas enquanto razão última a permitir a deturpação dos princípios republicanos. Na sanha irada dos fazendeiros maranhenses não indenizados pelo imperador estaria alojada não apenas as marcas culturais de uma sociedade retrógrada, mas o longo processo de estagnação financeira que lentamente se apoderou da província na segunda metade do século XIX.

Astolfo Marques não foi o único intelectual para quem as identidades inacabadas de ser negro e republicano eram conjugadas com alguns poréns. São conhecidas as tensões entre Luiz Gama (1830-1882) e o partido republicano paulista, devido ao modo duvidoso com que o partido incorporava a causa abolicionista ${ }^{1}$. O protesto do autor de Trovas Burlescas contra o Manifesto Republicano (1873), que apostava na lenta e gradual abolição do trabalho servil, ratifica que para o tribuno a forma de governo republicana só fazia sentido aliada à defesa intransigente da igualdade entre todos os cidadãos. Uma república consolidada por escravocratas seria, para ele, uma traição de princípios. Felizmente, o autor morreu antes de 1889.

\footnotetext{
${ }^{1}$ Em Orfeu de Carapinha, a historiadora Elciene Azevedo anotou com precisão as ambivalências que queremos elucidar, afirmando: "Tudo indica, no entanto, que a relação de Luiz Gama com seus correligionários obedeceu a uma lógica muito própria, que só pode ser compreendida se pudermos entender qual o sentido que ele dava em sua atuação como republicano e qual a República que defendia” (grifos meus, Azevedo, 2005, p.148).
} 
Outro exemplo ainda mais controverso é o de José Patrocínio (1854-1905), o famoso "tigre da abolição", que era republicano, mas aderiu ao chamado Isabelismo após proclamação da Lei Áurea, combatendo o preconceito daqueles que designou "republicanos do 14 maio", fazendeiros temerosos de que o fim da escravidão anunciasse também o fim do latifúndio. Acusado por seus ex-colegas das lides republicanas de condenar a viabilidade da democracia brasileira ao ter proferido em discurso que "enquanto houver sangue e honra abolicionistas, ninguém tocará no sangue da monarquia", o jornalista respondeu ao fim de um longo artigo:

O que não quero é escravizar o meu país a uma palavra [a república], que é a glória na Suíça, mas que é a vergonha no Peru, só para não parecer contraditório, quando, na realidade, sou coerente perante a Ciência Política sustentado, em nome do meu amor à liberdade, a Monarquia que nos promete a integridade e o progresso pela democracia rural, e opondo-me a essa república, também combatida pela A rua e de que nos resultará a landocracia a mais audaciosa, e a oligarquia a mais bestial. ([1889] 1996, p. 274).

O fantasma subjetivo da contradição intelectual e ideológica aparece em todas as linhas. O jornal A Rua era composto por escritores como Olavo Bilac, Coelho Neto, Raul Pompéia, amigos do jornalista que no momento estavam afastados do seu jornal Cidade Rio, devido ao vivo apoio de Patrocínio a sua "Redentora". O autor argumenta que para atingir sua coerência naquele momento teria de agir e usar de uma linguagem que o faria parecer um homem contraditório. Ser negro e republicano, no hiato entre 13 de maio e 15 de novembro de 1889, tornava-se difícil para o intelectual que viu na princesa regente uma alternativa viável de concretizar a "democracia rural", nossa ainda esperada reforma agrária. Mais ainda: ele argumenta que o monarquismo que ora defendia, na verdade, o isabelismo, tinha as mesmas virtudes e finalidades do republicanismo específico defendido pelo A Rua. Tudo leva a crer que José do Patrocínio também era do tipo que coloca barretes frígios em cabeça de reis.

Para o autor, a forma de governo não contém as bases da solução dos problemas sociais, tanto que a república é "glória na Suíça” e "vergonha no Peru”, sendo uma Monarquia que "nos promete a integridade e o progresso pela democracia rural", bem melhor do que a "landocracia", uma república governada pela audaciosa aristocracia rural brasileira, "a mais bestial". Entretanto as artimanhas do destino, ou de sua "Ciência Política", fizeram o tribuno entrar para história como o proclamador civil da república na câmara de vereadores do Rio de Janeiro. Pouco tempo depois deixaria o cargo argumentando que os seus eleitores foram excluídos do processo político (cf. ALVES, 2009, p. 251).

A frase Negro, Porém Republicano também perde um pouco do seu exotismo inicial se aceitarmos a sugestão da historiografia recente de que o republicanismo era uma 
ideologia rara entre a população negra do século XIX, geralmente restrita aos que nasceram livres, cresceram em áreas urbanizadas e gozavam de algum acesso à educação (ANDREWS: 1998, p. 78). Situação muito diferenciada da grande maioria de negros que eram escravos, analfabetos e viviam nas zonas rurais ${ }^{2}$. Além do que, "reis" e "príncipes" faziam parte da história nativa dos milhares de africanos transportados para o Brasil no comércio de escravos, "havia uma mentalidade monarquista, por assim dizer, circulando entre os negros, que parece ter sido recreação das concepções africanas de liderança, reforçadas em uma colônia, e depois um país governado por cabeças coroadas" (REIS, 1996: 32). De acordo com o mesmo historiador, em 1849 os rebeldes do quilombo de Queimado, no Espírito Santo, foram convencidos por seu próprio líder de que a rainha iria intervir por suas alforrias.

Como efeito, um dos principais êxitos do Segundo Reinado foi conseguir progressivamente, à medida que o regime escravocrata se tornava economicamente insustentável, aliar a imagem dos monarcas à propaganda abolicionista. A revolta dos exescravos maranhenses contra o jornal republicano $O$ Globo em 17 de novembro de 1889, informa em termos quase ideais o prestígio da coroa frente população negra. No Rio de Janeiro, a formação da Guarda Negra, grupo paramilitar fundado após o 13 de maio para defender a liberdade e expressar gratidão à Princesa Isabel arrasava comícios republicanos e reivindicava através de José Patrocínio, um de seus porta-vozes, o status de partido político (GOMES, 1991, p. 79). O resultado imprevisto na trama do liberalismo brasileiro, forjado à guisa da reflexões em torno da abolição, foi transformar o liberto num sujeito político cuja “integração” encerrava o dilema da modernidade à brasileira no fin de siècle.

Muito do prestígio político da Monarquia entre negros relacionava-se com essa cidadania iminente que a República veio a censurar. Sidney Chalhoub, analisando os significados da liberdade para os negros que habitavam os subúrbios cariocas nas primeiras duas décadas da república, assinala:

\footnotetext{
${ }^{2} \mathrm{O}$ inverso não é verdadeiro. Negros cultos e instruídos não faltaram à causa monarquista. O engenheiro André Rebouças (1838-1898) é um caso célebre. A ligação do autor com o império era tão visceral que optou por embarcar para exílio junto à família real após o 15 de novembro. Defensor de que o objetivo último do movimento abolicionista era o fim do latifúndio e o surgimento de um modo de produção à americana baseado na propriedade privada. Posição difícil mesmo entre abolicionistas fervorosos. De modo emblemático, numa correspondência ao amigo Alfredo Taunay, o autor representou seu "não-lugar" com o desenho de um triângulo equiilátero e em cada vértice os nomes de Joaquim Nabuco (liberal), Alfredo Taunay (Conservador) e o seu nome sem qualquer designação partidária, sem lugar próprio no jogo de poder, no médium entre as opções políticas institucionalizadas (CARVALHO, 1998).
} 
(...) na primeira década do século XX a classe trabalhadora carioca em geral, e a população negra em particular, já havia entendido que ao contrário das previsões do conselheiro Aires, a república trouxera mudanças. E havia saudade do tempo do imperador. Um observador atento e sensível como João do Rio chegou a ficar um tanto obcecado pelo tema da popularidade da monarquia entre a população pobre da Corte quase duas décadas depois da proclamação da República. Em Alma Encantadora das Ruas, um livro de crônicas publicado originalmente em 1908, João do Rio aborda a passagem em cinco passagens e contextos diferentes. Há inicialmente uma observação das tatuagens, uma prática bastante comum entre os populares: ao lado de fetiches e figuras religiosas complicadas, os negros traziam frequentemente a coroa imperial desenhada na pele; é verdade que alguns traziam o corpo ornamentado pelas armas da República, porém, o cronista concluiu: "Pelo número de coroas da Monarquia que eu vi, quase todo esse pessoal é monarquista". Mais adiante encontramos um cocheiro nostálgico, que se lembrava perfeitamente de que o imperador D. Pedro II costumava receber o príncipe Obá II no passo da cidade. Obá era liberto e veterano da Guerra do Paraguai, se dizia filhos de reis africanos, e tinha como seus vassalos os negros minas e as quitandeiras do largo da Sé. O cocheiro nostálgico resume suas impressões: "A Monarquia tinha as suas vantagens. Era mais bonito, era mais solene... Bom tempo aquele!” (1990, p. 183).

João do Rio chegou mesmo a ter certeza de que, dado o número de reis e rainhas que viu desfilar pelas ruas da cidade durante o carnaval carioca, na verdade, a massa era mesmo monarquista. Mas fiquemos inicialmente com a explicação do cocheiro. Para ele, a Monarquia tinha suas vantagens por ser mais bela e solene. Afora o fato de que D. Pedro II não ocupa sozinho às glórias de ser majestade. Na memória desse trabalhador sem nome na história escrita, o imperador brasileiro divide a realeza com o príncipe D. Obá II e as quitandeiras do largo da Sé. Talvez, aos seus olhos, seja essa mesma a razão das belezas do império.

Em As Barbas do Imperador, a antropóloga Lilia Schwarcz lança a hipótese que uma das razões para a pouca legitimidade dos símbolos republicanos no imaginário nacional assenta-se nas diferentes concepções da realeza partilhadas por senhores, livres e escravos no período colonial e imperial. Naquele mundo de D. Obá II, reisados, reis congos, rainhas de carnaval e do próprio imperador D. Pedro II, a "realeza representava uma instância de poder comum a diferentes universos culturais, nos rituais várias monarquias se encontravam, a despeito da total ausência de liberdade nas esferas sociais e políticas” (1998, p. 15). E, na república, pareciam estar bem mais aptos para simbolizar as esperanças frustradas de autonomia cultural e vida digna da população negra. Com efeito, um dos primeiros atos do governo provisório no Maranhão, portaria de 22 de novembro de 1889, era a destruição de "todos e quaisquer vestígios materiais do antigo regímen: coroas imperiais, bandeiras, insígnias e retratos do ex-imperador e membros de sua família" (cf. MEIRELES, 1994, p. 112). Daniel e seus amigos do bairro do Curupira tinham realmente motivos para temer ${ }^{3}$.

\footnotetext{
${ }^{3}$ Esclarecendo a política de destruição da memória simbólica do império no Maranhão, conta o historiador Mario Meireles: “(...) o jovem Casimiro Júnior, posto a testa da polícia, procedeu a uma incansável caça aos inimigos
} 
O historiador Sidney Chalhoub aventa duas hipóteses para continuidade da popularidade da monarquia entre a classe a trabalhadora da cidade do Rio de Janeiro na Primeira República (1889-1930). A primeira delas refere-se a uma compreensão eugênica das idéias de "progresso" e "civilização" na qual as culturas populares negras e mestiças da cidade tornam-se um alvo constantemente atacado pelas autoridades públicas que as consideram bárbaras ou mesmo produto da degeneração racial que habita o corpo escuro dos brasileiros. A outra é que essas mesmas políticas pretenderem remodelar a cidade, demolindo cortiços e expulsando os pobres do centro da cidade, também atacando os significados de liberdade ali impressos nas lutas cotidianas contra a instituição servil ${ }^{4}$.

Por essas e outras razões, a monarquia também foi uma bandeira coerente para diversos intelectuais negros brasileiros. O escritor Lima Barreto (1881-1922) na sua famosa crônica, Tribunal Histórico Republicano (1920), fora áspero e irônico na sua avaliação da república trinta anos após o golpe que levou o marechal Deodoro ao poder. Para o autor: "Uma rematada tolice foi a tal república. No fundo, o que se deu em 15 de novembro, foi a queda do partido liberal e a subida do conservador, sobretudo da parte mais retrógrada dele, os escravocratas de quatro costados" ([1920] 2001, p. 913). Essa mesma avaliação, comum entre os intelectuais negros que apoiavam a forma de governo em voga, fazia o autor de Triste de Fim de Policarpo Quaresma debicar dos que se orgulhavam de proclamar-se republicanos históricos, "estertores mais cômicos que a imaginação humana pode inventar" (Idem).

Ao contrário, como destaca o biógrafo Francisco de Assis Barbosa, as lembranças do autor referente à monarquia de sua infância são sempre cândidas e elogiosas. A memória do imperador D. Pedro II vem comumente associada à ampliação dos direitos de cidadania do povo. Causou-lhe grande impressão assistir junto a seu pai a proclamação da Lei Áurea, 13 de maio, dia do seu aniversário. Realeza e liberdade se combinaram indelevelmente nas recordações de Lima de Barreto. Quanto ao evento de novembro de 1889 rememora: “ $D a$

\footnotetext{
do novo regime. E, aos menos qualificados, além de prendê-los e castigá-los com palmatoadas, só mandava soltá-los com o estigma da cabeça raspada.

Nisso, mais sofriam os negros, ex-escravos, que não deixavam de manifestar sua gratidão à Redentora" (1994, p. 113)

${ }^{4}$ Com enfoque na pouca adesão ao projeto político da Guarda Negra em São Paulo, o historiador George Andrews formula explicações diferenciadas: "Devido a uma população menor em São Paulo, em comparação com o Rio, e um poder republicano muito maior na província, a Guarda Negra jamais conseguiu se estabelecer lá. Apesar disso, o sentimento monarquista era visível entre a população negra paulista. Em Jundiaí, os monarquistas expulsaram a força os republicanos do clube 13 de maio, uma organização social afro-brasileira, liderando represálias e brigas fora das instalações do clube. Em 1930, os jornais negros publicados na cidade de São Paulo traziam notícias de clubes e organizações monarquistas na comunidade negra; no mesmo ano, os membros da escola de samba Vai-Vai, atualmente uma das mais importantes da cidade como homenagem à monarquia (1998, p. 81).
} 
tal história da proclamação da república só me lembro que as patrulhas andavam, nas ruas, armadas de carabina e meu pai foi, alguns dias depois, demitido do lugar que tinha" (cf Barbosa, 1988, p. 44). O 15 de novembro marcou para autor a passagem da bonança para um período de autoritarismo, corrupção e queda social familiar.

Outro intelectual negro cujo monarquismo chama atenção é o paulista Arlindo Veiga dos Santos (1902-1978). Diferente de Astolfo Marques, Lima Barreto e José Patrocínio, o autor nasceu pouco mais de uma década após a derrocada do império. Neste caso, o seu monarquismo provém de uma profunda convicção ideológica e não de uma experiência social e política com as transformações na forma de governo. A atuação política mais relevante dessa liderança nos anos de 1920 e 1930 se dividiu entre a Ação Imperial Patrinovista Brasileira e as organizações negras paulistanas, tornando-se um dos fundadores e o primeiro presidente da Frente Negra Brasileira em 16 de setembro de 1931 (Domingues, 2006). Os seus esforços na Ação Imperial suscitaram de D. Pedro Henrique de Orleans e Bragança, herdeiro do trono brasileiro, uma carta onde destaca seu "inestimável serviço prestado ao Brasil e a Monarquia”.

Homem culto, formado em filosofia e letras, profundamente católico, antiliberal, anti-comunista e monarquista abnegado, Veiga dos Santos recusava-se a aceitar empregos públicos para não imiscuir-se com a república. Nas suas palavras: "A grande obra da ação negra no Brasil deve começar pela família pois que é ela uma célula-mãe de toda a sociedade civil. (...). É ela o protótipo da sociedade política ou estado mais perfeito, isto é monarquia" (Cf Domingues, 2006, p. 522). Desta maneira, o autor de A Lírica de Luiz Gama (1944), reunindo os dois programas políticos nos quais estava engajado, incitava os seus "patrícios" de cor a lutarem pela re-habilitação da monarquia brasileira, único regime capaz de completar a obra da abolição, por esta mesmo, promovida.

Essas anotações permitem enfatizar que ser negro, republicano, ou mesmo monarquista, para os intelectuais negros que construíram suas carreiras ao longo da derrocada do Segundo Império elou ascensão da chamada República Velha, não eram identidades culturais e políticas com significados fixos. Tal como enfatizava José do Patrocínio, podiam ser até mesmo palavras vazias, na verdade, "significantes flutuantes" alargados ou enxutos com maior ou menor grau de coerência, para abrigar a insurgência do negro como um sujeito político na restrita esfera pública brasileira. O que parece atravessar o pensamento desses homens tão diferentes é o sentimento de que o dilema da modernidade à brasileira encerra-se na singularidade das aspirações políticas do ex-escravo pela cidadania - gente que eles conheceram, ajudaram a conquistar alforria, ouviram suas estórias, brigaram, foram seus 
amigos, pais, avôs e bisavôs - a partir do insultante e conhecido lugar de negro. Ser um intelectual negro, têm sido, desde então, a capacidade para narrar a história com todas as frustrações dessa memória coletiva, no interior de linguagens políticas e estéticas comprometidas e avalizadas por esse mesmo processo de dominação. É uma arte que exige muitos "poréns".

O presente trabalho é uma investigação acerca de como Raul Astolfo Marques (1876-1918) enfrentou esse desafio. Fruto da geração de ex-escravos nascida sobre a égide da Lei do Ventre Livre (1871) e as transformações que levaram ao fim do trabalho servil e a capitulação da monarquia, o escritor logrou grande expressão pública no Maranhão da República Velha e conta entre os fundadores da Academia Maranhense de Letras. Na primeira parte desta dissertação intitulada Um Ilustre Desconhecido, tentamos compor a trajetória intelectual do escritor a partir de uma sociologia crítica das fontes na qual o autor é representado. Na segunda, As Cores da Aurora: história e contra-história da república, focaliza-se exclusivamente o romance A Nova Aurora no qual o autor expõe literariamente os significados da transformação política de novembro de 1889 para o povo brasileiro. 


\section{Cronologia}

1871 - Lei do Ventre livre

1873 - Celso Magalhães publica a série A Poesia Popular Brasileira

1876 - Nasce Raul Astolfo Marques

1881- É publicado o Romance O Mulato, de Aluísio Azevedo

1885 - É sancionada a lei do sexagenário

1888 - Abolida a escravidão

- Foi publicado Estudos sobre a poesia popular do Brasil, de Sílvio Romero;

1889 - É proclamada a República dia 15 de novembro.

- Levante de ex-escravos maranhense em defesa da Monarquia em 17 de novembro.

- Adesão do Maranhão à República.

1896 - Astolfo Marques ingressa como servente na Biblioteca Pública de São Luis.

1893 - Antônio Lobo assume a biblioteca pública de São Luís

1898 - Astolfo Marques ascende ao cargo de auxiliar da direção da Biblioteca Pública de São Luís.

1897 - É fundada a Academia Brasileira de Letras

1900 - É fundada Sociedade Literária Oficina dos Novos

1901 - Alfredo Teixeira e Antônio Lobo publicam a Revista do Norte

1902 - Graça Aranha lança Canaã.

1902 - Falecimento de Souzândrade

- Publicação de Os Sertões

1903 - Viriato Correa publica seu primeiro livro de contos Os Minaretes

1905 - Astolfo Marque publica A Vida Maranhense

1906 - Visita do Presidente Afonso Pena ao Maranhão

- Publicação do relato de viagem de São Luís à Teresina

- Morre Nina Rodrigues

1908 - É fundada a Academia Maranhense de Letras

1911 - Astolfo Marques assume a redação do cotidiano O Jornal

1913 - Publicação de A Nova Aurora

1916 - Morre Antônio Lobo

1918 - Morre Astolfo Marques 
RAUL ASTOLFO MARQUES

(1876-1918) 
PARTE I 


\section{Um Ilustre Desconhecido}

Numa viagem para fins diplomáticos e a divulgação do seu trabalho romanesco, o escritor Josué Montello (1917-2006) fez uma curta estadia na Suécia, entre os dias 23 e 28 de maio de $1982^{5}$. Passagem efêmera, mas atribulada de compromissos; entrevista na rádio, conferência na Universidade de Estocolmo, visita à Academia Sueca e jantares na embaixada brasileira. Tudo naquele lugar lhe parecera estranho. "A Suécia é o país da solidão militante" assevera o seu Diário da Noite Iluminada (1994, p. 324). Não se ouviam gritos, risadas, nem mesmo a buzina dos carros ou o ranger das rodas de ônibus que ensurdecem as grandes metrópoles. Uma sociedade de cidadãos envelhecidos condenada à melancolia do progresso. "Porque temos tudo, tudo nos falta", confessou-lhe um livreiro.

Talvez fosse justamente esse vazio que reclamava agora maior atenção à cultura brasileira na cena intelectual da Suécia. A televisão de Estolcomo embalava a noite fria de seus espectadores, exibindo por capítulos as trapalhadas do vagabundo Quincas Berro-d'Água por entre ruas sujas e bordéis calorentos nas noites tropicais de Salvador. O roteiro da entrevista de Montello na rádio nacional passava pela análise das obras de Carlos Drummond de Andrade, Gilberto Freyre, Jorge Amado e João Cabral de Melo de Neto. Mesmo durante a visita à prestimosa Academia Sueca, responsável pela outorga do prêmio Nobel de literatura, a surpresa preparada por Lars Gyllenstein, secretário perpétuo da instituição, ao embaixador brasileiro Claudio Garcia e ao escritor maranhense era a existência de uma estante inteiramente dedicada à literatura brasileira. A alegria da surpresa não pôde arrefecer nos brasileiros o sentimento de seu “atraso nacional”. Naquele dia, Josué anotou em seu diário:

\footnotetext{
${ }^{5}$ Josué de Sousa Montello foi um dos intelectuais brasileiros mais proeminentes do século XX. Nascido em São Luís do Maranhão aos dias 21 de agosto de 1917, ele viveu nessa cidade até a juventude, quando em 1936 veio a mudar-se para a então capital do Brasil, onde morou durante a maior parte de seus 88 anos de idade. Dotado de uma produção literária vasta, que vai do romance ao teatro, passando pela crítica, crônica e ensaio, Josué Montello tornou-se conhecido por sua prosa moderna vista sobretudo em Cais da Sagração (1971), Tambores de São Luis (1975), Noite sob Alcântara (1978), sem contar as novelas Duas vezes perdida (1966), Glorinha (1977), dentre outras. O escritor também dirigiu várias instituições de Cultura no Brasil, como a Biblioteca Nacional, Academia Brasileira de Letras, da qual chegou a ser presidente, o Museu Histórico Nacional, o Museu da República, do qual também foi fundador, além de participar como membro dos conselhos federais de Educação e de Cultura. Em sua trajetória também exerceu atividades diplomáticas como adido cultural em Lima, Lisboa e Madri.
} 
Sobre uma vasta mesa - tal como eu gostaria de ver na Academia Brasileira - estão expostas as revistas literárias mais recentes dos grandes centros culturais do mundo, sobretudo francesas, inglesas e alemãs. Enfileirados à minha frente, perfilam-se os dezessete volumes do Dicionário da Academia Sueca, trabalho de sucessivas gerações de seus dezoito acadêmicos. Por toda parte, ordem, limpeza, disciplina. A academia não existe apenas para outorgar seus prêmios anuais de repercussão mundial. Existe para o trabalho coletivo, no porfiado esforço de dar a língua uma disciplina gráfica e conceitual, abonando-lhe os vocábulos com os textos básicos da literatura sueca.

E Lars Gylenstein adianta-me:

- É pena que a Academia já esteja de férias e o senhor não possa assistir a uma de nossas reuniões de trabalho.

Subimos uma escada interna, e eu me vejo diante da vasta biblioteca, com os seus milhares e milhares de volumes, harmoniosamente dispostos em estantes que se deslocam à leve pressão do meu dedo.

- Quer ver a parte brasileira?

$\mathrm{E}$ eu, que jamais poderia retribuir a gentileza, mostrando-lhe a parte sueca na biblioteca da Academia Brasileira, dou comigo frente aos romancistas, aos contistas, aos ensaístas, aos poetas, aos teatrólogos do meu país. Eu próprio ali estou, numa tradução francesa, noutra cespanhola e noutra inglesa.

De súbito, outra surpresa: aqui está meu conterrâneo Astolfo Marques, num exemplar de A Nova Aurora, romance maranhense publicado em São Luís, em 1913, numa edição da Tipogravura Teixeira, com retrato do autor, e este parece que ri para mim, preto, colarinho alto, colete, uma flor na botoeira, o bigode comprido e horizontal. Deste livro me vali, como testemunho fidedigno, ao coordenar todo vasto acervo de subsídios sobre o negro maranhense, quando escrevi Os Tambores de São Luís. Como veio parar ali, saído de São Luís, o meu prestimoso conterrâneo? Reponho-o na estante e fico a pensar quando aparecerá por aqui outro maranhense, sabendo quem foi Astolfo Marques e o que significa seu livro esquecido (MONTELLO, 1994, p. 326).

Ordem, limpeza e disciplina são as palavras que definem o ambiente culto da Academia Sueca. A autoridade intelectual daquela instituição se insinua ao escritor pela constatação de que ali circulam os principais periódicos literários europeus, a organização exemplar da sua biblioteca e a constatação massacrante de que as instituições brasileiras dedicadas à cultura erudita nem sequer divisavam aquele grau de desenvolvimento. Por outro lado, na cuidadosa menção en passant da presença de sua própria obra na estante brasileira, citando "meticulosamente ao acaso" cada tradução estrangeira de seus próprios livros, ele procura estender o prestígio daquela academia ao seu nome. E depois, a um desconhecido conterrâneo, Astolfo Marques, cujo valor é medido por fornecer subsídios à história do negro maranhense. Com efeito, a presença inusitada de um desconhecido escritor negro brasileiro nas estantes da invejável biblioteca de Estocolmo era uma espécie de capricho cosmopolita a confirmar, mais uma vez, no coração ora vaidoso, ora um tanto envergonhado do intelectual latino-americano, ávido de reconhecimento internacional ${ }^{6}$, o universalismo da vida cultural européia.

\footnotetext{
${ }^{6}$ Nesse sentido, o autor registra em seu diário a euforia pessoal com que viveu sua recepção na Universidade de Estocolmo. Após assistir, emocionado, à análise detalhada que Regina Af Gejerstam, diretora do Departamento de Línguas Românicas daquela instituição, fez de toda a sua obra, afirma que "quando a professora me dá a palavra, corro o lenço na testa molhada, enxugo o suor que me desce para o cavado do rosto - enquanto reflito
} 
De fato, deparar-se com o romance A Nova Aurora no longínquo norte europeu foi uma experiência que impactou Montello ${ }^{7}$. Além das anotações do diário, o autor dedicou ainda uma crônica ao episódio, intitulada Astolfo Marques: um ilustre desconhecido, na qual estiliza um pouco mais sua surpresa:

\footnotetext{
Alonguei o braço para a prateleira mais próxima, com uma indagação mais viva nos olhos e nos dedos. Seria possível? Ali? Em Estocolmo? Na Academia Sueca? Um livro maranhense? De meu conterrâneo Astolfo Marques?

Sim, era verdade.

Fiquei a olhar o retrato de Astolfo Marques, contra a folha de rosto do volume, com saudades do tempo em que, na minha juventude, tive em mãos esse mesmo livro, na Biblioteca Pública de São Luís (MONTELLO, 1993, p. 119).
}

Tratava-se mesmo de um achado aparentemente inusitado. É notória a parca atenção que Raul Astolfo Marques (1876-1918) tem recebido da crítica especializada no Maranhão e o seu total desconhecimento do público brasileiro em geral ${ }^{8}$. A forma convencional de citá-lo na historiografia literária da "Atenas Brasileira" tem sido apenas do tipo “... e Astolfo Marques” (LUZ, 1954; MORAES, 1977; RAMOS, 1973). O escritor negro aparece mais como cenário do mundo intelectual maranhense que um de seus agentes. $\mathrm{O}$ autor raríssimas vezes é lembrado por sua produção ficcional, sendo plausível acreditar que a posteridade de seu nome foi resguardada quase exclusivamente por sua presença e atuação em periódicos e instituições que se tornaram, posteriormente, centrais nas narrativas canônicas sobre o campo intelectual ludovicense, tais como o grupo Oficina dos Novos, a Revista do Norte e a própria Academia Maranhense de Letras (AML).

Não sem razão, Montello cognominou o seu conterrâneo de “ilustre desconhecido". Para o escritor, era deveras surpreendente que um autor tão pouco citado, gozando apenas de edições locais sem maiores repercussões nacionais, pudesse ter uma obra preservada num dos logradouros mais prestigiados da chamada literatura universal. O termo também indica que a legitimidade de Astolfo Marques como imortal - devemos informar que

que, na minha volta ao Brasil, quando eu confessar que, em Estocolmo, ao proferir uma conferência, suei mais do que havia suado em Teresina, noutra conferência, correrei o risco de passar por mentiroso" (MONTELLO, 1994: 327-28). O contraponto divertido entre Estocolmo e Teresina mostra a consciência aguda do autor acerca das relações de poder que perfazem a consagração intelectual e o modo como o mesmo procura manipulá-las.

${ }^{7} \mathrm{O}$ escritor Jomar Moraes, amigo pessoal de Josué Montello, contou-me que em suas repetidas visitas a capital maranhense lembrava alegremente do fato dizendo: "Eu vi lá o preto, todo arrumado, colarinho alto, camisa de cazimira e flor na botoeira".

${ }^{8}$ Neste sentido, é digno de nota o pequeno verbete dedicado a Astolfo Marques no Dicionário Literário AfroBrasileiro, organizado pelo pesquisador Nei Lopes (2007: 27). 
o escritor é o fundador da cadeira $\mathrm{n}^{0} 10$ da $\mathrm{AML}$ - não é plenamente assegurada pela comunidade literária que herdou o direito a sua memória. É praxe das academias de letras coordenarem vastas pesquisas sobre a história de seus membros e fundadores. Aquilo que chamamos de imortalidade, longe de sintetizar o efeito imediato da magnificência do texto na apreciação pura do leitor culto, seria melhor descrita como o conjunto de discursos pertencentes a um aparato institucional, neste caso as próprias academias, que gerenciam a memória oficial dos escritores escolhidos para serem lembrados como clássicos; assim como vedam a obra dos que foram selecionados para o esquecimento público.

Daí, nossa aproximação analítica com a vida e obra de Astolfo Marques intentada neste trabalho interessar-se inicialmente pelas reminiscências de Josué Montello. Na verdade, interessar-se pela relação entre memória, espaço e consagração intelectual que aparecem de maneira tão intricada nas lembranças do escritor. Elas me permitem informar que o exercício de objetivação sociológica efetuado nas páginas seguintes está profundamente marcado pelas de relações poder que dão significado às contradições do epíteto "ilustre desconhecido". O fato social que coagiu esta pesquisa para os arquivos mal guardados, as revistas esquecidas, jornais podres e quebradiços, livros nunca re-editados, páginas que os fungos tornaram ilegíveis, as zonas silenciosas da memória coletiva.

Eu me incluo entre aqueles cientistas sociais que ajuízam o mérito, o acerto ou a relevância dos
resultados alcançados em parte como decorrência do domínio que o autor demonstra ao lidar com
as fontes e materiais de que se serviu. Tal passo se revela indispensável àqueles estudiosos para
quem as definições correntes sob quaisquer objetos são parte do objeto que se pretende desvendar,
ou melhor, que não existe a rigor separação ou descontinuidade entre o objeto e os materiais que
falam dele, que o expressam ou que de alguma maneira lhe dão alguma forma de existência. Vale
dizer, os modos de operação, os valores, a cultura política dos grupos, os sentimentos vigentes de
hierarquia, os padrões de relacionamento, enfim, todas as características materiais e mentais das
elites estão como que inscritas nas fontes que elas produzem (ou subsidiam, ou encomendam) e
que, no mais das vezes, falam desses grupos com eles apreciam que se fale deles (MICELI, 2009,
p. 162).

Tal posição metodológica impõe a questão: de que maneira Astolfo Marques se inscreve na materialidade das fontes que lhe conferem existência? Em outras palavras: quais a características dos documentos que garantem a imortalidade do escritor negro? O objetivo do presente capítulo é justamente examinar "a cultura política dos grupos", "os sentimentos vigentes de hierarquia", "as características materiais e mentais das elites", impressas nos dados que tornam o autor estudado numa realidade empírica passível de análise sociológica. 


\section{Vida Versus Obra}

O único esforço de catalogação sistemática da obra de Astolfo Marques conhecido ocorreu por ocasião do centenário de nascimento do autor em 1976. Ao que tudo indica tratava-se de um projeto destinado a constituir fontes para o estudo da história intelectual do Maranhão, focalizando inicialmente os fundadores da Academia Maranhense de Letras. A cooperação entre a instituição literária, a Secretaria de Imprensa e Obras Gráficas do Estado (SIOGE) e a Fundação Cultural do Maranhão originou a pequena cartilha Astolfo Marques: publicação comemorativa do $1^{o}$ centenário do autor.

A composição é organizada em quatro partes. A primeira seção intitulada Traços Biográficos onde é sumarizada a trajetória do escritor apresentado. A segunda parte é constituída por uma espécie de "modelo exemplar" da obra comemorada: o conto Pastores Gorados do livro Natal (1908). A terceira, Opiniões Críticas, reúne uma seleção mínima de comentários acerca do trabalho intelectual do autor. A última seção é composta por uma bibliografia com quarenta e duas referências de produções do autor entre livros, artigos, contos, apontamentos biográficos, seguida do excerto Fontes Bibliográficas Sobre Raul Astolfo Marques com mais dez notações direcionadas à pesquisa do autor (Ver Anexo).

A principal característica desse documento é seu caráter institucional. Malgrado a coleta das referências bibliográficas ter exigido necessariamente um esforço de pesquisa pessoal ou coletivo os responsáveis diretos pela execução do trabalho não são nomeados. É como se a autoridade simbólica do boletim comemorativo repousasse sobre a sua impessoalidade. O material, embora em grande medida destinado a estudiosos, não contém qualquer esclarecimento de ordem metodológica. Ao folhear a cartilha não se tem qualquer idéia de como aqueles resultados foram obtidos ou mesmo sua real abrangência quantitativa frente à totalidade da produção intelectual do escritor. ${ }^{9}$ Por conseguinte, também não é possível mensurar se os dados coligidos oferecem um quadro representativo do projeto intelectual do autor, ou seja, se apresentam informações que permitem restituir analiticamente as ambições literárias de Astolfo Marques ao longo da sua carreira.

\footnotetext{
${ }^{9}$ Esses problemas são particularmente prejudiciais quanto à menção, sem qualquer indicação de referências, do livro inédito Nas Esquinas e Vielas (memórias). O acesso a essa obra ou trechos da mesma permitiria investigações sociológicas que lançassem mão do método prosopográfico no estudo de Astolfo Marques. Supomos que o autor possa ter publicado alguma parte nos diversos jornais de que era colaborador ou ter mencionado o livro na entrevista que concedeu ao jornal Anais (03/11/1910), citada na seção de fontes bibliográficas, embora hoje perdida nos arquivos da Biblioteca Pública de São Luís ou indevidamente na mão de particulares.
} 
Apesar das deficiências metodológicas da publicação, a cartilha, devido ao caráter eminentemente institucional da edição, nos oferece um ponto de vista privilegiado para nos aproximar das formas publicamente apreciáveis de se comemorar - usado aqui no sentido etimológico de fazer memória coletivamente do antigo, usual e clássico - a presença de Astolfo Marques na história da literatura maranhense.

O tópico "traços biográficos" pretende sumarizar quais os momentos chave da trajetória de Astolfo Marques que o público interessado precisa saber para compreender como o mesmo tornou-se um escritor proeminente do seu tempo. Segue o texto:

Nasceu Raul Astolfo Marques em São Luís do Maranhão a 11 de abril de 1876 e faleceu na mesma cidade em 20 de maio de 1918.*

Descendendo de gente humilde, conheceu o trabalho exercendo pequenas tarefas, ora ajudando a velha mãe na entrega da roupa lavada, ora levando recados. Mas, de extrema vivacidade, aprendeu cedo a ler e a escrever e pôde assim obter o primeiro emprego regular como servente da Biblioteca Pública, então dirigida por Antonio Lobo.

Naquela casa de estudo não perdeu tempo e nas horas de folga lia tudo o que podia, dando-se pressa em melhorar seus conhecimentos. Espanava e etiquetava livros, arrumando-os nas sólidas estantes de cedro, mas lia-os igualmente e isso serviu-lhe muito para a suas futuras experiências literárias.

Antonio Lobo dirigia a Biblioteca Pública com incomparável eficiência e proibidade e com ele, sob o mesmo teto, na missão de soerguer o Maranhão intelectual, trabalhavam Fran Paxeco, de origem portuguesa, escritor laborioso e fecundo, e Francisco Serra, poeta e contista.

Os três formavam o esteio da "Oficina dos Novos", sociedade literária que tanta influência exerceu no processo de renascimento de nossas tradições literárias. Astolfo Marques, pertinaz, vontadoso, encontrou em Lobo e nos outros dois amigos uma fonte de preciosos estímulos e o apoio de que necessitava. Fizeram-no secretário geral da "Oficina dos Novos" e logo colaborador do boletim que a sociedade editava sob o título de "Os Novos".

Lendo os escritores mais característicos da língua, aprovisionando-se fortemente em Eça de Queirós, seu modelo preferido, Marques começou a escrever uma série de contos regionais retratando a vida popular do Maranhão. Nada lhe escapou da vida maranhense de então: as festas de igreja, batizados, casamentos, velórios, reisados, rodas de S. Gonçalo, queimações de palhinha, os ritos de quaresma, as folganças carnavalescas, as danças folclóricas, o tambor de crioula, o bumba-meu-boi, as romarias a S. José de Ribamar, enfim todos esses recortes coloridos do viver provinciano ele abordou em flagrantes verdadeiramente admiráveis.

Exemplo dignificante de autodidata, figurando o que escrevia nos melhores jornais e revistas de sua época, Marques trabalhou sem medir horas, surdo ao despeito e a inveja que vez por outra tentaram macular-lhe a obra.

Não é por certo um grande escritor mas suas narrativas calcadas no dia a dia de nossa gente serão lembradas pela maneira sincera, objetiva com que visualizava as cenas. "Natal", "A Vida Maranhense", os contos que estampou na "Revista do Norte" serão sempre lidos com prazer por quantos desejarem conhecer nossos usos e costumes e a própria linguagem popular nas duas primeiras décadas deste século.

Astolfo Marques é fundador da Academia Maranhense de Letras, onde instituiu a cadeira ${ }^{\circ} 10$, patrocinada por Antonio Henriques Leal.

$\mathrm{Na}$ imprensa colaborou na "Revista do Norte", "Diário Oficial", "O Jornal", "Diário do Maranhão", "Os Novos", "Pacotilha", "A Imprensa" de Viana etc. Com Antonio Lopes e Domingos Barbosa fundou em 1912 a revista "Ateneida".

Foi durante algum tempo secretário e arquivista da Associação Comercial do Maranhão, levado para ali pela mão generosa de Fran Paxeco, secretário interino da Instrução Pública e do Liceu Maranhense e Secretário da Delegacia Geral da Liga Marítima Brasileira no Maranhão. Exerceu

*Na verdade o autor só veio a falecer no dia 28 de maio vitimado por uma tuberculose. 
ainda a função de correspondente do Jornal do Comércio, de Caxias, "O Norte”, de Barra do Corda e "O Comércio", de Teresina.

Além de copiosa produção estampada em jornais, livros e revistas deixou inéditos os seguintes trabalhos: "Quatro Anos de Crônicas", "Esboços e Quadros" - 1905-1909, 2a e 33 séries do volume publicado com o título de "A Vida Maranhense", "Seleta Maranhense", coletânea de trechos em prosa e verso, de 45 escritores maranhenses, com bibliografia completa e retratos e "Nas Esquinas e Vielas", memórias.

A narrativa prioriza a contraposição entre a origem humilde do escritor e sua proeminência intelectual nas duas primeiras décadas do século XX. A negritude do autor não é mencionada. A baixa posição social de Astolfo Marques é assinalada pela ausência de menções ao pai, pelo trabalho de lavadeira de sua mãe e pela sugestão de que o mesmo fora na infância apenas um menino de recado que não freqüentou os bancos escolares. Pertinácia, vivacidade, esforço e vontade são os aportes explicativos primários que permitem compreender a conversão do menino destituído num intelectual respeitado. Não fossem esses atributos pessoais que o inclinaram para a leitura e a escrita precocemente seria difícil conquistar o posto de servente regular da Biblioteca Pública de São Luís - instituição apontada como responsável pelo cultural turn do autor.

A conquista do emprego formal é o segundo aspecto enfatizado nestes traços biográficos. A capacidade que o servente estudioso teve para conquistar o apoio dos intelectuais que arrogaram para si a "missão" de soerguer a cultura literária local. Antonio Lobo $^{10}$, Fran Paxeco ${ }^{11}$ e Francisco Serra ${ }^{12}$ são considerados os principais estímulos que o então contínuo precisava para inserir-se no mundo das letras. O cargo de Secretário Geral da

\footnotetext{
${ }^{10}$ Antonio Lobo (1870-1916) iniciou seus estudos no Colégio de São Paulo e adentrou no Liceu Maranhense. Depois de formado, assumiu a cadeira de docente na instrução pública. Como possuía inserção e parentesco com figuras importantes da política maranhense, ele deixou o cargo de professor para assumir a posição de Oficial de Gabinete de Dr. Cassimiro Dias Vieira Junior no ano de 1893. Mudando-se apenas para ocupar o lugar de diretor na Biblioteca Pública, cargo que assumiu interinamente em 1897 e como efetivo em 1898. Em termos de produção bibliográfica, Lobo enquanto dirigia a Revista do Norte destacou-se por suas traduções. Contam entre as suas produções o romance "A Carteira de um Neurastênico" (1903), além dos livros Positivismo e Micróbio (1908), Doutrina Transformista (1909) e Os Novos Atenienses (1909).

${ }^{11}$ Fran Paxeco (1874-1952) é como ficou conhecido o português Manuel Francisco Pacheco que aportou aos 26 anos na ilha de São Luís a 02 de maio de 1900, causando certo impacto na jovem geração de intelectuais maranhenses interessados em promover culturalmente a cidade através da literatura. Tido como um literato de fervoroso engajamento republicano, Paxeco colaborou com algumas das principais instituições de Educação e Cultura que vieram a se formar em São Luis (Moraes, 2008, p11-13). Paxeco assumiu a função de Cônsul de Portugal no Maranhão - em 21 de agosto de 1911, nomeado por Teófilo Braga, à época chefe do Governo Provisório da República Portuguesa (LUZ, p.66), e permaneceu neste cargo até os anos de 1922. Dentre sua produção bibliográfica destacam-se O Maranhão e seus recursos (1902) e Os interesse Maranhenses (1904) e a Geografia do Maranhão (1922).

${ }^{12}$ Francisco Serra possui uma trajetória intelectual ainda nebulosa. Fundou dia 28 de julho com Astolfo Marques e João Quadros, o grêmio literário A Oficina dos Novos. Migrou para o sul do país ainda na primeira década do século passado. Morreu vítima da tuberculose em 1914.
} 
Oficina dos Novos e a colaboração na revista Os Novos seriam as consequiências diretas do papel formador desses homens na carreira do humilde funcionário da biblioteca.

Esses "padrinhos" de Astolfo pertencem àquela classe de funcionários públicos que intentou desenvolver uma carreira literária no momento de constituição das grandes burocracias intelectuais, na verdade, parte do seu êxito deve-se, no caso do Maranhão, ao empenho de erigir um parque institucional de "organização da cultura" "13. Com efeito, a movimentação dos chamados "novos atenienses" nas primeiras três décadas do período republicano, é responsável pela criação das principais burocracias intelectuais do Estado como Academia Maranhense de Letras (1908), a Faculdade de Direito (1918), a Faculdade de Farmácia e Odontologia (1922) e o Instituto Histórico e Geográfico do Maranhão (1925) (MARTINS, 2006, p. 179).

O ponto alto da tensão entre origem social e consagração intelectual que alimenta a sinopse biográfica é a descrição da obra de Astolfo Marques. Ao lado de uma esforçada tentativa de ascensão social, um "exemplo dignificante de autodidata", temos uma obra de pouca grandeza literária. Em seus livros, contos esparsos e crônicas não existe força criadora no trato com as palavras mas sim o observador fiel da realidade. Quanto a isso é taxativo em sua avaliação: "Não é por certo um grande escritor mas suas narrativas calcadas no dia a dia de nossa gente serão lembradas pela maneira sincera, objetiva com que visualizava as cenas". A leitura de Astolfo deve dirigir-se, portanto, àquilo que seu texto possui de registro histórico. Trata-se de uma obra tão marcada pela observação estrita do circundante que não consegue transcender seu objeto estético imediato, pois incapaz de transmitir beleza para além do que meramente descreve. O prazer da fruição literária só será atingido por aqueles que desejarem conhecer os usos e costumes do folclore maranhense, a linguagem popular, as festas religiosas regionais, enfim, a cultura local.

É precisamente a pouca "universalidade" da obra de Astolfo Marques que dirige as razões da comemoração para o seu "exemplo de vida". O que devemos celebrar neste autor é antes a façanha do menino de recados que se torna um escritor reconhecido entre seus pares do que sua literatura propriamente dita. Idéia reforçada ao fim da sinopse pela listagem da intensa colaboração do autor em diversos jornais da província e os postos públicos que alcançara seja pela "mão generosa" dos amigos e/ou pela sua competência. Não sem razão, no mesmo ano da publicação do Boletim, o governo do estado inaugurou no vestíbulo do prédio-

\footnotetext{
${ }^{13}$ De acordo com o sociólogo Sérgio Miceli: "Na ausência de uma definição estrita da atividade intelectual como tal, bem como das vias que a ela conduzam, a posição em falso com relação à oligarquia constituiu decerto o trunfo mais seguro para que pudessem se inserir nesse mercado em expansão (2001, p. 53).
} 
sede da Academia Maranhense de Letras, cujo logradouro é o mesmo onde outrora funcionava a Biblioteca Pública, uma placa de bronze com os seguintes dizeres: "Raul Astolfo Marques (1876-1918). Nesta casa começou humilde e nela glorificou seu nome nas letras maranhenses. Homenagem do Governo do Estado em 11/04/1976”. Eis a memória oficial do escritor. $^{14}$

Neste sentido, o Boletim deve ser entendido como um artefato simbólico que atravessa uma rede complexa de divisão social do trabalho significativo que envolve intelectuais, instituições dedicadas à produção e a divulgação da cultura erudita, mandatários regionais e a memória das elites dirigentes. O documento pretende a "eficácia simbólica" de institucionalizar um parecer definitivo e isento de maiores contestações, a narrativa mestra capaz de justificar a imortalidade de Astolfo Marques, uma vez que o nome do autor converteu-se num ente significativo em que as alianças entre os intelectuais e as elites dirigentes locais são material e simbolicamente negociadas.

É preciso destacar que as principais reedições de textos relativos à história social e intelectual do século XIX, almanaques administrativos, memórias, compêndios, dicionários histórico-geográficos, literatura em verso e prosa, além dos chamados Apontamentos e Panoramas, formas textuais preferencialmente adotadas pelos comentadores regionais para escrever a história da literatura local, têm sido patrocinadas, concebidas e editadas às expensas do poder político estadual. É o caso dos programas editoriais Coleção São Luís (1970-72) e Maranhão Sempre (2000-2002). Um caso ímpar nesse sentido é a coleção

\footnotetext{
${ }^{14}$ Em Apontamentos Sobre Astolfo Marques, crônica jornalística que integra as observações do escritor Carlos Gaspar, titular da cadeira $\mathrm{n}^{\mathrm{o}} 1$ da AML, esse modelo de canonização foi contestado: "Devo externar o sentimento contrário que tenho em relação aos que, quando a ele se reportam, de hábito dão destaque à sua "origem humilde", como se essa condição social pudesse ser um entrave a quem nasceu para amar as letras e com a decisão de cultivá-las. Da mesma forma divirjo da crítica que fazem ao seu talento, como a que está manifesta na publicação comemorativa ao seu centenário de nascimento, feita pela Fundação Cultural do Maranhão, datada de 1976: "Não é por certo um grande escritor"...

A afirmação de que Astolfo Marques é de "origem humilde" e "não é por certo um grande escritor" pode ser entendida como preconceituosa. Afinal, inúmeros foram e são os intelectuais que nasceram de família extremamente pobre. E, afinal, o que é ser um grande escritor? Não há definição, e sim conceitos vagos e pessoais. Pena e cultura não são privilégios dos ricos." (O Imparcial, 05/10/2008). Observe que o autor só consegue criticar a tensão entre vida e obra que caracteriza a memória pública de Astolfo Marques, menosprezando o monopólio que tradicionalmente as elites possuem acerca do trabalho intelectual. Assim, "o preconceito" da afirmação de que Astolfo Marques é de "origem humilde" e "não por certo um grande escritor" não teria motivações sociais ou raciais, mas de ordem lógica, desconsidera que "inúmeros foram e são os intelectuais que nasceram de família extremamente pobre".
} 
Documentos Maranhenses (1984) que celebra aliança entre o grupo empresarial ALUMAR, o governo do estado e a Academia Maranhense de Letras ${ }^{15}$.

\begin{abstract}
Organizadas na última década por comentadores regionais tais coleções limitam-se a reedições ou a primeiras edições brasileiras, tão somente endossando as classificações prevalecentes. Ao objetivar resgatar títulos consagrados de épocas pretéritas, consideram que eles são auto-evidentes, ou seja, falam por si só e dispensam explicações ou análises críticas. Os comentadores frigorificam os textos, tal como sucedera com seus autores, como se a unidades discursivas se mantivessem constantes, alheias à dinâmica das representações sociais sobre elas, e não pudessem ser reinterpretadas, re-classificadas e dotadas de sentidos outros que não aqueles originais. O livro para eles é mais um discurso pronto, acabado e tornado peça inerte ou de sentido ornamental na coleção de bibliófilos e de colecionadores. Nada de teria de um argumento dinamicamente recolocado, passível de ser criticado e destituído do peso que historicamente lhe foi imputado (ALMEIDA, 2008, p. 8).
\end{abstract}

A concepção do Boletim Comemorativo não é um caso a parte. O tópico Fontes Bibliográficas Sobre Astolfo Marques que integra a quarta seção do boletim comemorativo sumariza, para o caso do autor, essas referências autorizadas: 1) Anônimo. "Astolfo Marques". In: Os Anais, Ed. 03/11/1910. São Luís; 2) Anônimo. "Raul Astolfo Marques” In Antologia da Academia Maranhense de Letras. São Luís, 1958; 3) Antonio Lobo. "Astolfo Marques". In: Os Novos Atenienses. Maranhão, 1909; 4) Domingos Vieira Filho. "Raul Astolfo Marques e a Associação Comercial". In Boletim da Associação Comercial do Maranhão. 1954. São Luís ; 5) Domingos Vieira Filho. "Raul Astolfo Marques.” Revista do Maranhão. I vol. Fasc. VI. Junho 1951. São Luís; 6) Fran Paxeco. “Astolfo Marques”. In Pacotilha, ed, 28/06/1918. São Luís. Transcrito na Revista da Academia Maranhense de Letras. Vol. II. São Luís, 1919. 7) Humberto de Campos. "O último estio de Atenas”. In: Memórias Inacabadas. Rio de Janeiro, 1935; 9) Mario Meireles. Panorama da Literatura Maranhense. São Luís, 1954; 10) Antonio de Oliveira. "O centenário de um contista maranhense: Astolfo Marques. In: O Estado do Maranhão 10/03/1976. São Luís.

Essas referências subsumem a quase totalidade dos escritos conhecidos sobre Astolfo Marques. Acrescenta-se a essas notações as crônicas Astolfo Marques: um ilustre desconhecido e Apontamentos Sobre Astolfo Marques ambos já citados neste trabalho e cuja bibliografia se serve exclusivamente das referências supracitadas. Observe-se que a crônica e o verbete são os principais estilos nos quais o escritor negro é escassamente analisado. Inexistem biografias ou pesquisa de crítica literária dedicada a sua obra. São textos muito curtos, os maiores contendo no máximo três páginas, interessados em oferecer um panorama

\footnotetext{
${ }^{15}$ Vale informar que a única re-edição de Astolfo Marques foi subsidiada pela coleção Documentos Maranhenses por ocasião do centenário da Academia Maranhense de Letras (2008), quando uma obra de cada de um dos fundadores da agremiação literária foi publicada.
} 
genérico sobre o autor. Para compor a sinopse biográfica do boletim comemorativo, recorreu substantivamente a dois artigos: Astolfo Marques (1919) de Fran Paxeco e Raul Astolfo Marques (1951) de Domingos Viera Filho ${ }^{16}$.

O primeiro texto é um necrológio. Publicado originalmente com o título de A Lei da Morte dia 28 de Junho de 1918 no jornal A Pacotilha, registrando a emoção de Fran Paxeco há exatos trinta dias da morte do amigo. Move a pena do escritor português, a sensação de que todo o trabalho de Astolfo Marques pela literatura maranhense seria ingrata e rapidamente esquecido.

Faz hoje trinta dias que Raul Astolfo Marques sucumbiu. Um padre solícito rezou uma segunda
missa pela sua alma. Os filhos ficaram na miséria e os seus companheiros de trabalho, a breve
trecho, esquecer-se-ão dele e do esforço que representou a sua vida, para subir a restrita nomeada
em que a morte o arrebatou. O egoísmo humano é feroz. E no entanto o Raul merece mais alguma
coisa do que missas - e do que o olvido cruel dos colegas.
A sua função, sem revestir o brilho que ostentou a maioria dos seus pares de jornada, cujas
tendências se diferençavam das que lhe incutiam coragem pro labor diário, - essa função foi por
ventura de maior eficácia para gerações futuras. Deblaterava-se bastante, a data, contra o
nefelibatismo - e um crítico definiu o nefelibata como o habitante da lua. Ora o Raul nunca teve
em grande apreço as musas, e sobretudo as dos lunáticos. Preferia a prosa vil e rasteira, que força a
mais torturas do que os mais remontados poemas.
Dentro desse critério, pôs-se a observar as usanças da sua terra e descrevê-las. Faltava-lhe o sopro
idealista, - o pólen poético, se quiserem classificá-lo dessa maneira. Cingia-se a uma reprodução
quase literal do que se lhe defrontava, porque a imaginação o desservia. Assim, aos sequiosos de
simbolismo, as suas novelas pareceram áridas. Outros, porém, que se aferram a realidade, aos
processos naturalísticos da arte, apreciaram essa característica das suas páginas, achando-lhes um
sabor não comum. E qual era? A de retratarem com, com a simpleza duma fotografia, as
personagens e os quadros que o rodeavam. É que o Raul se preocupava com a cor local - o
regionalismo, a que o Viriato [Corrêa] imprimiria, depois, um novo cunho, de mais gosto e
requinte, mas sem maior exatidão. Salvou, dessa forma, alguns tipos citadinos ou panoramas
amortecidos, que a inabalável razoira dos tempos reduziu a pó (PAXECO, 1919, p. 77).

Os comentários de pesar e ressentimento acerca da morte do confrade enfatizam a discrepância entre o "esforço", que representou sua vida para seguir o ofício de escritor, e uma sugerida indiferença ou desprezo por sua pessoa entre os companheiros de trabalho. Expressões como "o egoísmo humano é feroz" e "olvido cruel dos colegas" ratificam, sem nos esclarecer a termo, a existência de tensões entre o escritor e o meio literário de São Luis. A triste anotação de que os filhos de Astolfo Marques ficaram na miséria indica a instabilidade das posições sociais conseguidas pelo escritor, incapazes de gerar para sua família ascensão social sólida. A Lei da Morte, título original do texto, assinala que para Fran

\footnotetext{
${ }^{16}$ Informo que o artigo Raul Astolfo Marques e a Associação Comercial (1954) de Domingos Vieira Filho publicado no Boletim da Associação Comercial do Maranhão é tão somente uma re-publicação do texto Raul Astolfo Marques (1951). Alteram-se apenas algumas palavras e frases de efeito no corpo do texto sem comprometer a estrutura da crônica publicada três anos antes.
} 
Paxeco, a morte do amigo não veio como o coroamento da imortalidade, significava tão somente o esquecimento e a derrota social.

É contra essa "injustiça do destino" que o cônsul português escreve o necrológio. E mais uma vez se a grandeza da vida de Astolfo Marques dispensa comentários não se pode dizer o mesmo da obra ficcional. Fran Paxeco assevera que o autor "não ostentou o brilho dos seus parceiros de jornada", era um escritor menor entre seus pares. Embora pondere que os afeitos aos "processos naturalísticos" poderão conferir valor a sua prosa, emite um juízo profundamente negativo. Mesmo a opção de Marques pelo estilo literário realista e regionalista é analisada como sintoma de um problema cognitivo, "a imaginação o desservia", assevera duramente. Trata-se de uma literatura que desprovida de idéia enterra-se na descrição. Nesta perspectiva aristocrática, se a função do artista é criar mundos inexistentes ou ao menos recriar a sua realidade, desnudando belezas que a vida cotidiana veda aos homens restritos a linguagem ordinária, qualificar a obra de Astolfo Marques como plenamente "artística" seria uma contradição nos termos. Vale dizer: uma contradição alimentada pelo desserviço da inteligência que ao invés de repetitiva devia ser criadora.

Entretanto um aspecto redime a ficção de Astolfo Marques: sua eficácia para as gerações futuras. É como se a incapacidade do autor para imaginar houvesse premiado sua obra com registro histórico da vida maranhense na alvorada do século XX. Em seus textos, podemos encontrar a realidade transformada em palavras, cenas objetivas com a simplicidade de uma fotografia que perenizam as peculiaridades do viver regional. Em suma: basta apenas ignorar os fatores estéticos para encontramos o valor dessa literatura.

Esta fórmula interpretativa (vida versus obra) está presente nos textos de Domingos Vieira Filho. Escritos mais de trinta anos após o necrológio de Fran Paxeco, armam-se do mesmo respeito pela vida difícil de Astolfo Marques temperado por duras críticas a sua obra. Entretanto, os interesses que mobilizam os textos são profundamente distintos.

Domingos Vieira Filho faz parte da plêiade de intelectuais brasileiros articulados ao Movimento Folclórico Brasileiro. Em 1949, o pesquisador assumiria a Secretaria Geral da Sub-Comissão Maranhense de Folclore, visando à construção de um campo próprio de estudos nessa área, bem como institucionalizá-la nas políticas públicas de cultura. Com este fim, trabalhou durante dez anos à frente do Departamento de Cultura ligado à Secretaria de Educação do Estado, junto aos governos Newton Bello (1961-1966) e José Sarney (19661970). Em 1971, o referido departamento transformou-se na Fundação Cultural do Maranhão (FUNC-MA), presidida pelo pesquisador no governo Nunes Freire (1975-1979). Portanto, a 
edição do Boletim Comemorativo através da FUNC em 1976, que ora analisamos, é parte da política cultural encetada pelo próprio Domingos Vieira Filho.

Além de sólida carreira institucional, Domingos Vieira Filho escreveu ensaios que se tornaram referências obrigatórias para o estudo do folclore maranhense. Tudo leva a crer que fora seu interesse pelas manifestações populares que o conduziu ao estudo da obra de Astolfo Marques. No livro Populário Maranhense (Bibliografia) (1982), o autor cita a importância de obras como A Vida Maranhense e Natal para a "fixação de costumes" e danças como o carimbó, o extinto batidinho e o catolicismo popular. Talvez por isso, quando analisa a trajetória do autor, confere destaque à questão racial:

Raul Astolfo Marques, como tantos outros escritores brasileiros, notadamente Machado de Assis,
foi produto de si mesmo. Não teve reclamos luminosos em sua carreira literária e esta, apesar
brilhante, não foi das mais fáceis. Era pobre e de cor. Em 1890 aqui na província ainda
predominavam os preconceitos de cor, as idéias de linhagem e de fidalguia. O mulato - Aluízio
Azevedo fixara magistralmente essa mentalidade no célebre romance "O Mulato" aparecido em
1881 - era visto com indisfarçável malquerença, um surdo desdém que não tinha, em absoluto,
razão de ser. A cor nada significa e nem nos dá a conhecer a inteireza moral de um indivíduo.
Tivemos muitos homens de cor notáveis. Patrocínio, o gigante de ônix da Abolição, Luís Gama,
tribuno de valor, Cruz e Souza, torturado poeta simbolista, André Rebouças, engenheiro e
conselheiro de Estado, Juliano Moreira, cientista de renome mundial, Teodoro Sampaio, geógrafo
e tupinólogo, etc. Daríamos uma lista de valores negros se esse fosse o nosso intento neste
cantinho da revista.
Astolfo Marques teve, assim, que lutar contra duas forças diferentes mas poderosas: a pobreza e o
pigmento. Da pobreza nunca conseguiu se libertar de todo. Vez por outra ela vinha sorrateira,
encontrava o homem desprevenido e o tomava de assalto. Do pigmento, pouco a pouco se libertou
com a revelação de seu talento, conseguindo cercar-se de admiradores sinceros (VIEIRA FILHO,
1951, p. 5).

Agora não se trata apenas de um escritor de "origem humilde" mas de um escritor negro. Astolfo Marques figura na galeria dos "valores negros" que orgulharam a nação por sua contribuição política e intelectual. O enobrecimento da trajetória de Astolfo Marques é efetuado a partir da sugestão dos preconceitos raciais que o autor teve que enfrentar para seguir sua vocação literária. O que merece destaque é ter sido ao mesmo tempo intelectual e negro num Maranhão dominado pelas idéias de linhagem e fidalguia. Tal como Vieira Filho acrescenta na re-publicação do artigo na singela homenagem à passagem de Astolfo Marques pela Associação Comercial do Maranhão, move-o uma "admiração aleitado no respeito a sua obra literária, construída a custa de ingentes sacrifícios, que se não excele em fulgurações geniais se eterniza, contido, pela nota humana de que está impregnada”. Deste modo, são os “ingentes sacrifícios”, realizados pelo autor, o critério mais adequado para julgar sua obra. Se a escrita é destituída de fulgurações geniais, não menos incríveis e admiráveis foram os obstáculos ultrapassados para tentar viver da pena e do papel. 
Estes dados tornam o cognome "ilustre desconhecido" mais interessante do que pode parecer à primeira vista. As narrativas que constituem a imortalidade de Astolfo Marques elaboram uma tensão entre vida e obra, nas quais a grandeza da vida é constantemente ameaçada pela pequenez intelectual da obra. Deste modo, a consagração e o reconhecimento do autor, como um clássico da literatura maranhense, têm como prerrogativa o silêncio e/ou a desvalorização de sua produção artística. Por outro lado, a vida do escritor também não é investigada, sua valorização ancora-se nas vagas sugestões dos preconceitos que o literato provavelmente enfrentou, levando-se em consideração a época em que viveu. Mas são apenas conjecturas. Não existe nenhum esforço biográfico autêntico. A invisibilidade intelectual do autor é o modo paradoxal que os agentes do campo intelectual maranhense escolheram para preservar sua glória. Em outras palavras: não há como fazê-lo ilustre, senão, pelo seu caráter de desconhecido. 


\section{Os Periódicos Literários}

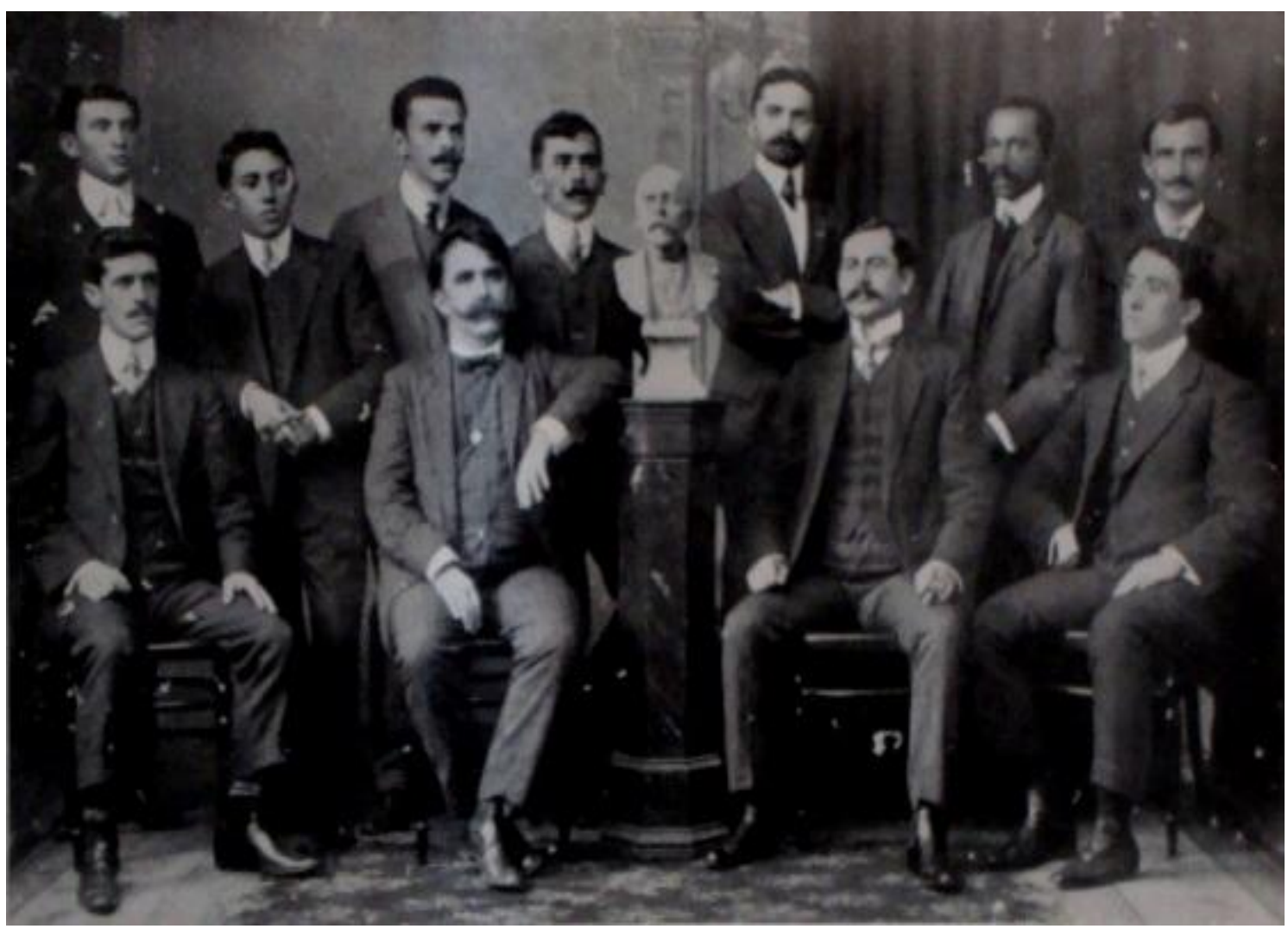

(Sentados da esquerda pra direita: José Luso Torres - Antonio Lobo - Fran Paxeco - Sebastião Sampaio. Em pé da direita para esquerda: Jerônimo José Viveiros - Raul Astolfo Marques - Luís Carvalho - Alfredo de Assis Castro - Edgar Almeida - Raimundo Correia de Araújo - Raul Soares Pereira).

Dentre as quarenta e duas referências bibliográficas acerca dos trabalhos publicados por Astolfo Marques coletadas para o Boletim Comemorativo vinte e seis delas provém de periódicos literários. Em ordem, decrescente temos vinte notações apontando $A$ Revista do Norte, cinco para o boletim literário Os Novos e apenas uma indicação para o periódico Avante (VER ANEXO).

Embora não fosse possível averiguar se a premência das revistas literárias no catálogo fosse um indicador satisfatório de que as mesmas constituíam o aporte inicial mais adequado para reconstituir as ambições literárias de Astolfo Marques, estas nos permitem relacionar a trajetória do autor a projetos intelectuais mais amplos bem como captar as redes sociais do escritor no meio cultural erudito.

Outra vantagem que os periódicos literários ofereciam para esta investigação era a adequação ao corte temporal aqui adotado. Toda a pesquisa que realizamos em fontes 
primárias está circunscrita ao período entre 1900 e 1918. A justificativa para essa periodização encontramo-la nas páginas do livro Os Novos Atenienses (1909), de autoria de Antonio Lobo. Escrito por um dos homens apontados como padrinhos da ascensão social e intelectual de Astolfo Marques, o objetivo desta obra era contar a história recente da intelectualidade maranhense no primeiro decênio do século XX. Ao relatar o clima de efervescência que dominava a freqüentada Biblioteca Pública e a casa do Padre Damasceno Ferreira, esclarece o autor:

Tomavam habitualmente parte nesses cavacos, quase todos os rapazes maranhenses que se sentiam
inclinados para letras, não só os que haviam estreado nos periódicos que aludimos no Capítulo II,
como também os vindos depois, a muito dos quais, até então, faltara ainda a coragem de jogar a
publicidade os seus primeiros ensaios. Foram esses exatamente, como Francisco Serra, Astolfo
Marques, João Quadros e outros, que Fran Paxeco mais animou, desfazendo-lhes os receios,
corrigindo-lhes os escritos, amparando-os com a sua coragem e impulsionando-os com o seu
exemplo. Todos eles, que hoje ocupam posição saliente na lista dos cooperadores diretos da nossa
renascença espiritual, reconhecem e proclamam os serviços que devem ao brilhante escritor de $O$
Sangue Latino (LOBO, [1909] 2008: 48-9).

O texto acima pretende enfatizar a influência do jornalista português Fran Paxeco à "renascença espiritual" do Maranhão. Ele teria estimulado moços como Francisco Serra, Astolfo Marques e João Quadros a darem publicidade aos seus primeiros textos. Uma vez que Fran Paxeco chegou ao Maranhão somente a 2 de maio de 1900, tive razões para estabelecer este ano como marco inicial para levantar a bibliografia de Astolfo Marques até o ano de sua morte em 1918. A produção intelectual do mesmo nos periódicos literários, tal como consta no boletim comemorativo, também remonta ao ano de 1900, pude considerar que essas revistas são capazes de flagrar os primeiros passos do jovem Raul na carreira artística.

É provável que os trabalhos mais antigos de Astolfo Marques em órgãos especializados tenham vindo a lume pela primeira vez no boletim literário Os Novos. $\mathrm{O}$ pesquisador Antonio de Oliveira na crônica O Centenário de Um Contista Maranhense sugere, provavelmente com base na entrevista concedida pelo autor em ANAIS (03/11/1910), que o escritor já tinha arriscado seus primeiros contos na década de 1890, entretanto seriam trabalhos só tardiamente conhecidos. Fato subsidiado por Antonio Lobo quando valoriza, talvez em demasia, o papel desempenhado por Fran Paxeco ao encorajar outros jovens talentosos da mocidade maranhense a levar seus textos a público.

O boletim Os Novos era o órgão de divulgação da agremiação literária Oficina dos Novos fundada a 28 de julho de 1900. Data escolhida em homenagem à adesão do Maranhão a Independência do Brasil em 1823. A nota divulgada pelo grupo no jornal A Pacotilha, no mesmo dia da fundação, levou a público a disposição dos cargos administrativos da nova 
corporação literária. A presidência ficou a cargo de José do Nascimento Moraes, ex-aluno brilhante do Liceu Maranhense, contando apenas com 18 anos de idade. A secretaria geral ficou em mãos de Octávio Almeida, Raul Astolfo Marques assumiu a função de tesoureiro da associação recém criada, no entanto, também executava trabalhos de ordem burocrática como a escrita de notas de divulgação da Oficina para os jornais assim como elaboração e leitura dos relatórios durante as reuniões. A nota também menciona que Raimundo Leôncio Rodrigues e Manoel George Gromwell ocuparam posições de suplência na agremiação.

O Memorial Histórico da agremiação composto e lido por Astolfo Marques, na sessão solene de encerramento dos trabalhos em 16 de dezembro de 1902 esclarece a organização e os principais projetos da Oficina. Os quais eram: 1) o programa editorial Biblioteca da Oficina dos Novos, que visava editar as obras dos escritores filiados a instituição; 2) o Busto de Odorico Mendes a ser colocado numa praça cívica de mesmo nome em homenagem ao tradutor maranhense de Homero; 3) produção e divulgação de Os Novos, boletim literário da Oficina; 4) realização de festas cívicas, como a comemoração da Independência dia 28 de julho de cada ano.

Ao longo dos seus três primeiros anos de existência a associação estabeleceu três categorias de sócios: efetivos, correspondentes e honorários. Os sócios efetivos, cognominados de operários, eram os responsáveis por toda a organização burocrática da instituição: preparavam as reuniões, controlavam a tesouraria, a redação e a venda do boletim Os Novos, promoviam concursos literários, e comemoração de festas cívicas em homenagem ao passado político e literário do Maranhão e elaboravam o programa editorial dos livros de seus membros.

Os sócios correspondentes eram uma peça importante no funcionamento da Oficina. Geralmente compostos por maranhenses radicados em outros estados brasileiros, realizavam o trabalho de venda e divulgação do boletim Os Novos em diferentes partes do país. A expansão e influência do programa intelectual da mocidade maranhense de 28 de julho dependia do êxito desses agentes. Também é possível que os correspondente colaborassem no recrutamento de grandes personalidades nacionais para o cargo de sócios honorários do grupo. As informações contidas no Memorial Histórico, bem como nas notas de jornal divulgadas pela agremiação, registram a existência de correspondentes em Fortaleza, Teresina, Recife, Belém, Manaus, Rio de Janeiro além municípios do interior do Maranhão e Piauí. 


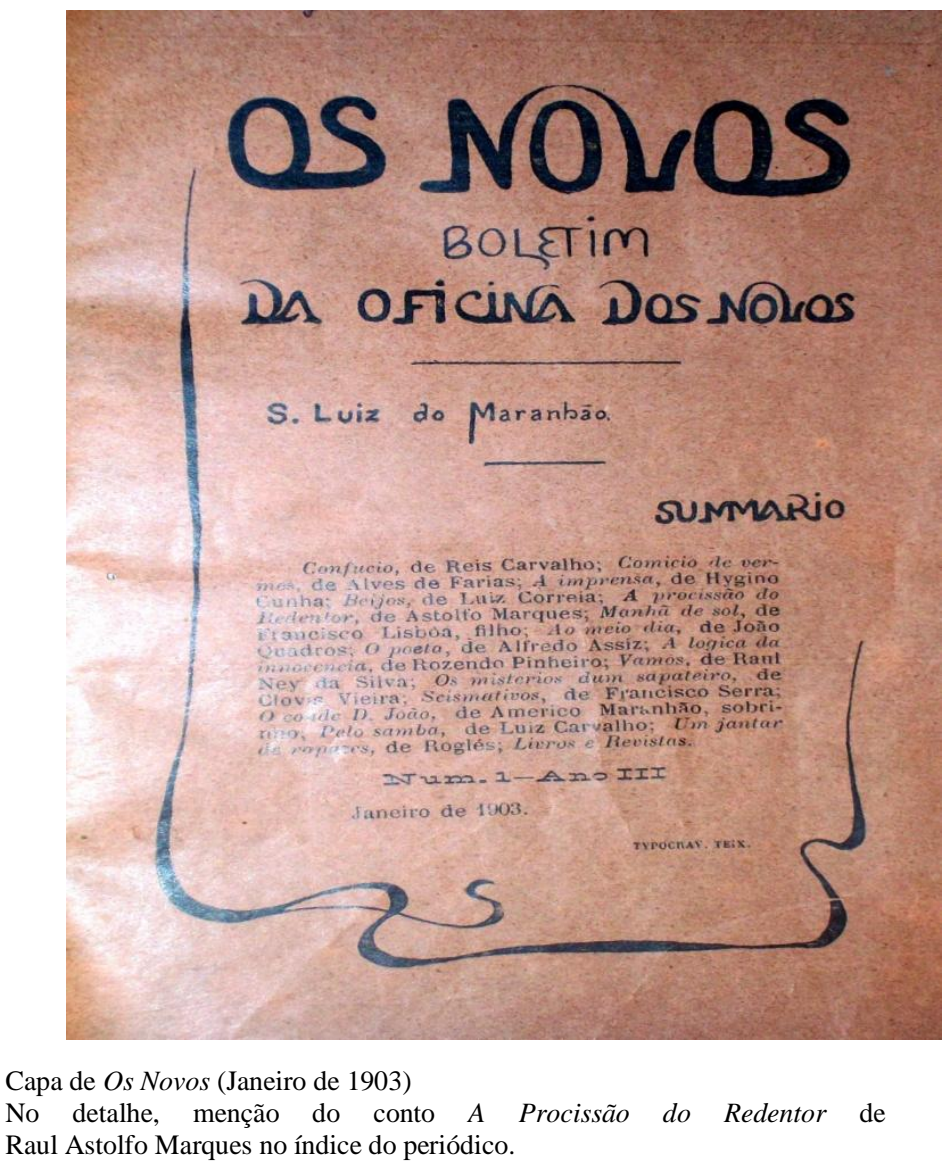

Os sócios honorários eram uma categoria de distinção intelectual. Só eram eleitas para esses cargos aquelas personalidades consideradas representativas no meio literário local ou nacional. Não tinham qualquer função na estrutura administrativa da Oficina. O seu trabalho, um dos mais importantes, era conferir prestígio e respaldo intelectual para as atividades e os membros da agremiação. Eles eram os padrinhos dos jovens operários, os responsáveis pela "eficácia simbólica" do grupo. Antonio Lobo e Fran Paxeco foram eleitos nessa condição 15 de setembro de 1900. Em maio de 1901, o poeta Sousândrade ingressa como presidente honorário do grupo. O dramaturgo Arthur Azevedo também foi incorporado nessa categoria, no dia 8 de dezembro de 1901. O Memorial informa o ingresso de vinte e três personalidades eleitas para essa categoria no ano de 1902 das quais citamos o médico Raimundo Nina Rodrigues, os escritores Graça Aranha, Coelho Neto e Machado de Assis, o político e embaixador Barão do Rio Branco, o crítico literário José Veríssimo, Teófilo Braga dentre outros.

A escolha desses sócio-honorários entre destacados membros da Academia Brasileira de Letras, figuras proeminentes da política nacional como o Barão do Rio Branco e maranhenses consagrados como Nina Rodrigues, Graça Aranha e Arthur Azevedo, dão-nos a medida das ambições intelectuais da Oficina dos Novos. Observe-se entre os sócios a presença 
de Teófilo Braga, destacado intelectual positivista português, amigo de Fran Paxeco, flagrando o esforço de inserção internacional do grupo. Com efeito, os membros honorários tentaram viabilizar o projeto de inserir a literatura produzida no Maranhão nos circuitos intelectuais mais prestigiados da sociedade brasileira com foros no exterior. Os intelectuais maranhenses bem posicionados no campo intelectual e político brasileiro eram os vetores mais acessíveis para essa empreitada. Duas pequenas cartas publicadas em Os Novos nos revelam um pouco dos bastidores desse processo:

\section{Uma Carta de Nina Rodrigues}

Sr. Astolfo Marques, dig. Mo Secretário Geral da Oficina dos Novos em Maranhão - Recebo, neste momento, a comunicação de que a Oficina dos Novos quis me distinguir com a eleição de sócio honorário. Muito grata é para mim a distinção dessa lembrança dos meus jovens patrícios, cuja generosidade, nunca desmentida, não esquece os que longe do torrão natal aspiram prestigiarlhe o nome e as tradições. Se a idade e a orientação não me permitem mais ser um novo, na generosa aspiração dos nossos ideaes, todavia um novo serei em não regatear louvores à mocidade que se empenha na elevação e cultura do espírito.

Aeitai meus protestos de estima pessoal e por mim agradecei aos nossos consócios a distinção que me conferiram.

Bahia, 20 de maio de 1902

Nina Rodrigues

\section{Uma Carta de Aluízio Azevedo}

Aluízio Azevedo - Consul du Brésil - La Plata. 25 de junho de 1902. - Meu ilustre confrade e conterrâneo Astolfo Marques, Secretário Geral da Oficina dos Novos. - Foi com a maior satisfação que recebi sua amável carta de 25 de abril passado, acompanhada de um exemplar do interessante "Boletim da Oficina dos Novos", em cujas páginas, justificando o sugestivo título da agremiação há um tal perfume de mocidade e um tal brilho de esperanças, que a leitura delas nem só encanta a inteligência, como alegra a alma.

É verdadeiramente lisonjeado que, por seu intermédio, agradeço a "Oficina dos Novos" o cativante serviço de me haver concedido o título de sócio honorário, honroso favor ao qual procurarei corresponder na medida dos meus pequenos préstimos.

Com muito apreço e gratidão,

Aluízio Azevedo

Trata-se de dois verdadeiros atestados de legitimidade intelectual para a Oficina. Em 1902, a atuação de Raimundo Nina Rodrigues como pesquisador e lente da Faculdade de Medicina da Bahia já o havia consagrado como um dos poucos cientistas brasileiros de reputação internacional. Livros como As Raças Humanas e a Responsabilidade Penal (1894) e O Animismo Fetichista dos Negros Brasileiros (1900) o tornaram o principal representante do determinismo racial no país, paradigma dominante nas instituições brasileiras de ensino superior. Não menos importantes eram as palavras de estímulo e aprovação de Aluízio Azevedo, exercendo nesta data atividades diplomáticas no exterior. Romances como $O$ Mulato (1881), Casa de Pensão (1884) e O Cortiço (1890) fizeram do escritor o mais 
proeminente romancista do gênero naturalista no Brasil.

Observe-se que as duas cartas se dirigem a Astolfo Marques na condição de secretário-geral da Oficina dos Novos. Função conquistada após as dissensões internas do grupo que marcaram o fim do primeiro semestre de 1900 e todo ano de 1901. A experiência na gerência de arquivos, que o trabalho na Biblioteca de São Luís lhe conferira, parece ter sido de excelente proveito. A posição de secretário-geral embora de menor status que a de presidente ou vice-presidente possibilitava o controle prático de todas as atividades desempenhadas pela agremiação. O êxito com que Astolfo Marques desempenhou essa tarefa possibilitou-lhe diversas re-eleições para o cargo até a desintegração do grupo nos dois primeiros anos da década de 1910. Nas palavras de Antonio Lobo: "como secretário geral dessa agremiação, cabe-lhe o incontestado direito de ser reconhecido e proclamado o mais dedicado e o mais esforçado de seus membros. Foi graças a seus esforços perseverantes que a Oficina progrediu e se desenvolveu, tornando-se mais unida e mais forte (...)” (2008 [1909], p. 117).

Com efeito, não é por acaso que dois dos mais destacados intelectuais maranhenses da época se dirigem pessoalmente ao mero servente da Biblioteca Pública na condição de digníssimo consócio. Astolfo Marques mobilizou com eficácia todo o controle pessoal e institucional que a atividade de secretário-geral lhe permitia, tais como a preparação das atas, encaminhamento das notas sobre atividades do grupo aos principais jornais da cidade, subscritas por seu nome, coordenação dos relatórios e memoriais históricos do grupo, comunicação direta com os ilustres sócios honorários, lugar cativo no boletim Os Novos, em fonte de visibilidade pública e prestígio intelectual no meio literário maranhense. Em suas Memórias Inacabadas o escritor Humberto Campos (1886-1936) flagra em tom jocoso, o contraste entre a posição subalterna do escritor frente a seus pares e sua inusitada centralidade na cena cultural maranhense:

Uma figura houve, entretanto, no Olimpo, que permitiu minha aproximação. Foi Raul Astolfo Marques, que se tornou conhecido, mais tarde, nas letras regionais, como Astolfo Marques, unicamente. Era homem de cor, de tez escura e embaciada, como a dos negros que sofrem do fígado. De estatura mediana, a fronte larga e fugidia, boca enorme e bigode ralo, possuía dentes enormes e brancos, que fazia aparecer a cada instante, sob a beiçorra da raça. Era amanuense da Biblioteca, mas desempenhava todos os misteres de servente: varria o salão, espanava as estantes, etiquetava os livros, enchia o filtro, molhava uma planta que havia à porta, e atravessava duas, três vezes, diariamente, a rua, para ir buscar na "Casa Transmontana", um refresco para Fran Paxeco, Francisco Serra ou Antônio Lobo. Era, segundo me disseram, filho de uma preta, lavadeira e engomadeira. E a isso devia ele, talvez, a alegria de exibir, pondo em destaque o seu terno de casimira azul-marinho, cuidadosamente passado a ferro, os mais duros e lustrosos colarinhos do Maranhão.

Humilde e obscuro, mas infatigável no estudo e no trabalho, Astolfo Marques fez-se de tal modo indispensável aos homens brancos a quem servia, que, na organização da "Oficina dos Novos", 
eles se viram forçados a dar-lhe um lugar a seu lado. Em breve, era ele o secretário-geral da associação. Escreveu, então, em estilo sem brilho, mas de observação meticulosa e precisa, quatro ou cinco volumes de contos e de pesquisas históricas. E acabou tuberculoso, como Francisco Serra, aos trinta e poucos anos de idade.

Eram esses os chefes do movimento literário cujo objetivo era a ressurreição de Atenas, e que se processava naqueles anos de 1900 a 1901, a poucos passos de mim. De um lado da rua, em torno as mesas, curvados sobre os livros, eles estudavam discutiam e meditavam. Do outro lado, eu, um saco de estopa sobre os joelhos, metia chumbo miúdo pelo gargalo das garrafas vazias [grifos meus] (CAMPOS, 1957, p. 71-2).

Este trecho reúne afirmações e juízos de grande autoridade sobre a vida e obra de Astolfo Marques. As pequenas notas existentes sobre sua produção, por vezes, soam como um refrão das opiniões de Humberto de Campos. O memorialista o conheceu pessoalmente quando contava apenas 14 anos de idade e trabalhava de balconista na Casa Transmontana, quitanda localizada nas imediações da Biblioteca Pública, muito antes de imaginar que se tornaria um escritor de renome nacional com assento na Academia Brasileira de Letras. É o jogo de espelhos entre a dolorosa rememoração dos trabalhos baixo escalão e a privação do desejo de estudar que sofrera Humberto durante toda a juventude e o amanuense que "fazia todos os misteres de servente", mas ainda sim era um dos "chefes" do movimento literário regional que o permite captar, não sem embaraços, as ambivalências da posição de Astolfo Marques.

Neste sentido, as palavras de Campos não expressam apenas o perfil do autor, mas dimensões do espaço simbólico em que ambos viveram. No relato, nota-se que a posição de Astolfo Marques como subalterno é qualificada não apenas pelo caráter dos trabalhos de baixo escalão que desempenhava como varrer salão, espanar estantes, molhar plantas, ir duas ou três vezes pegar sucos para seus patrões e etc., mas também racialmente: ele é o filho da preta engomadeira que servia os brancos. É a própria qualificação pejorativa de sua corporalidade negra (tez escura e embaciada, beiçorra da raça) que confere inteligibilidade à baixa posição social do autor frente aos demais homens de letras do seu tempo.

Todas as menções, tão francamente racistas, com que Humberto de Campos se refere ao autor traduzem a dificuldade de se conceber como o filho de uma preta engomadeira, funcionário humilde da Biblioteca Pública, conseguia lentamente galgar sólida projeção nas letras regionais. Ao denotar a submissão do autor numa referência grosseira aos “dentes", típica da mentalidade escravista, e contrapô-la sutilmente a civilidade e dignidade que o mesmo procurava exibir com o seu terno de casimira cuidadosamente passado a ferro e os "mais duros e lustrosos colarinhos do Maranhão", Humberto Campos constrói o retrato de um individuo fora do lugar, ou melhor, de um sujeito que risivelmente queria deslocar o que a própria natureza fixou em sua "tez escura e embaciada como a dos negros que sofrem do 
fígado".

A ambivalência que os preconceitos de Humberto de Campos o impedem de penetrar era que justamente ao desempenhar todos os "misteres de servente", "buscar um suco para Antonio Lobo", "empanar as estantes", "molhar as plantas", conhecer todas as maneiras de ser servilmente agradável e ao mesmo tempo ser "infatigável no estudo e no trabalho" Astolfo Marques convertia-se numa espécie de "funcionário total", um ente indispensável ao projeto intelectual dos brancos a quem ele servia. Numa frase: o segredo da projeção de Astolfo Marques é que ele deslocava sua posição social deixando a hierarquia classista, racial e intelectual em que estava enredado, aparentemente intocada. Observemos alguns dos comentários que o articulista da coluna Coisas e Loisas do jornal A Pacotilha, sob o pseudônimo de Ariel, tece acerca do escritor negro três dias após sua morte:

Modesto, nunca o viram tentar épater le burgeois, inculcando-se de gênio, nem mesmo para inglês
ver. Também não ambicionava muito, não se sobrepunha a quem quer que fosse e nunca o viram
envolvido em polêmicas e lutas de qualquer gênero, conquanto umas e outras não faltassem no
ambiente político e literário que respirava, tão içado de competições mesquinhas, de paixões
pessoais, de malquerenças, animosidades perfídias, invejas, futricas e outras coisas ignóbeis (...) $(A$
Pacotilha, 31 de Maio de 1918).

Os elogios de Ariel a "modéstia" e "humildade" do autor expressam o mesmo entrave paternalista que tornam indecifráveis as estratégias de ascensão social e projeção intelectual acionadas por Astolfo Marques tal como nos pequenos verbetes e apontamentos sobre autor. Astolfo Marques permanece apenas humilde e obscuro - as palavras são de Humberto de Campos - porque lutou pelos seus interesses próprios do lugar de negro, manipulando os valores e símbolos de superioridade racial e distinção cultural dos homens brancos com quem estabeleceu relações aliança, solidariedade e concorrência. $\mathrm{O}$ faxineiro negro que pretendia ser um intelectual consagrado convenceu a todos que não tinha qualquer ambição. A figura pública de um homem modesto, que não queria sobrepor-se a ninguém, totalmente inofensivo, sem qualquer vaidade, arredio a polêmicas e disputas mesquinhas, foi o trunfo eficaz com que o servente negro conseguiu estabelecer-se como um dos chefes do movimento literário regional.

O sucesso dessa alternativa na trajetória intelectual de Astolfo Marques é evidente. Afirma Fran Paxeco: Fran Paxeco que "Astolfo Marques foi um dos esteios seguros da Oficina dos Novos, que uma evolução natural converteu na Academia Maranhense, consagrando-se nesta diversos dos sócios efetivos e honorários daquela” (1919: 79). Neste caso, o trabalho do escritor negro como secretário geral Oficina ao longo de praticamente toda 
a primeira década do século passado é um dos fatores que permitem compreender sua projeção intelectual e consagração como um dos imortais fundadores da Academia Maranhense de Letras.

O boletim comemorativo do primeiro centenário de Astolfo Marques cataloga cinco trabalhos do autor publicados em Os Novos: 1) Os Vultos Maranhenses. Gonçalves Dias; 2) Emilio Zola; 3) O Vinho do Núncio; 4) Gonçalves Dias e a Influência de Sua Personalidade Literária; 5) Damasceno Ferreira: o jornalista (Ver Anexo). Trata-se de uma seleção composta por quatro estudos biográficos e apenas um conto literário, a saber, $O$ Vinho do Núncio.

A ausência de esclarecimentos metodológicos no referido material não nos permite conhecer se a relação acima é fruto de uma escolha dos trabalhos de Astolfo Marques considerados mais significativos ou se agências de preservação documental existentes na capital maranhense em 1976 só preservavam de Os Novos os exemplares supracitados. Em ambos os casos, é preciso informar que uma gama considerável da produção do autor no referido periódico foi completamente ignorada, permanecendo desconhecida aos contemporâneos $^{17}$. Dentre eles, destaca-se a série de cinco pequenos estudos etnográficos publicados no intervalo de 1900-1902: O Cancioneiro Maranhense; O Romanceiro Maranhense; Os Tipos Populares I: O Caroba; Os Tipos Populares II: O Troíra; Os Tipos populares III; O Pomada.

A importância desses estudos não reside apenas no seu ineditismo para a geração atual, mas no fato de que é possível recuperar através deles o interesse do autor em construir um painel etnográfico da cultura popular maranhense, bem como os principais autores que o influenciaram. Nos primeiros parágrafos de O Cancioneiro Maranhense, Astolfo Marques apresenta algumas das razões que justificam a realização desse tipo de pesquisa:

Iniciamos hoje um modesto estudo sobre o folk-lore maranhense, cujas bases foram lançadas no
Brasil pelo malogrado e talentosíssimo poeta, romancista e crítico Celso Magalhães, nosso
inolvidável conterrâneo. Estas pesquisas depois foram continuadas, com mais ou menos acerto,
pelos Srs. Koseritz, Sílvio Romero, Mello Moraes Filho e outros.
Os focos originários do folk-lore são a Bahia e o Maranhão, devendo notar-se que o movimento
comercial nesse tempo estabelecido entre os sertões dessas duas então províncias foi o mais sólido
agente dessas relações.

Vale à pena informar que o texto foi publicado no primeiro número de Os Novos saído dia 5 de agosto de 1900. O que faz considerar que seja provável que o autor já viesse

\footnotetext{
${ }^{17}$ Apenas Domingos Vieira Filho cita um artigo da série “Tipos Populares", escrita por Astolfo Marques, em Populário Maranhense (Bibliografia) (1982, p. 14).
} 
dedicando sua atenção à cultura popular maranhense, bem como ao repertório intelectual existente sobre o assunto anos antes da publicação. Note-se que uma das principais justificativas para a realização desses estudos é a retomada da agenda de pesquisa do “inolvidável conterrâneo" Celso Magalhães (1849-1879), autor escolhido por Astolfo Marques como patrono de seu assento na Oficina dos Novos.

Com efeito, os estudos do "malogrado poeta" com o de título A Poesia Popular publicados no jornal recifense $O$ Trabalho em 1873 e, simultaneamente em $O$ Domingo, na capital maranhense, são considerados o primeiro esforço de interpretação científica do folclore nacional. Morto aos 29 anos de idade, não pôde dar continuidade a suas investigações, entretanto, o amigo Sílvio Romero, reuniu seus trabalhos em sua famosa antologia Estudos Sobre Cultura Popular (1888), garantindo-lhe o reconhecimento nacional. Desta feita, sob o patronato de Celso Magalhães, o "modesto estudo" de Astolfo Marques tinha a pretensão de reivindicar para intelectualidade maranhense o pioneirismo nos estudos científicos sobre folclore e arrogá-lo um de seus representantes no meio literário local.

A segunda justificativa que ampara a necessidade de investigar a cultura popular maranhense é que o Maranhão e a Bahia são considerados pelo autor "os focos originários" do folclore brasileiro. Assim, quando se está diante do cancioneiro maranhense tocamos a essência da alma nacional, somos reportados a mais tenra origem da nacionalidade no sentido histórico e metafísico do termo. Eis porque o "movimento teórico" de Astolfo Marques no texto supracitado é baseado na distinção modelo e variante. O autor cita cinco quadras de versos populares do cancioneiro maranhense, que por ser o foco originário do folclore, são o ponto de partida da análise. Logo após, relaciona, com base nos Cantos Populares do Brasil de Sílvio Romero, as variantes, isto é, todas as quadras de versos semelhantes à estrutura das primeiras encontradas nas regiões brasileiras fora do "foco originário". No texto em questão, todas as variantes citadas vêm, oportunamente, do longínquo Rio Grande Sul.

As observações etnográficas e a inflexão cada vez mais regionalista emergem juntos ao longo dos volumes de Os Novos. Mesmo em se tratando dos estudos sobre folclore, apenas o texto $O$ Cancioneiro Maranhense adota uma estrutura exclusivamente analítica. Tanto O Romanceiro Maranhense quanto a série Os Tipos Populares lançam mão de amplos recursos ficcionais. Ao invés de descrever seu objeto de análise, por vezes, o autor opta por selecionar as principais características do fato analisado e constrói um tipo ideal, uma personagem.

A mescla desses estilos permite a escrita de Astolfo Marques o trânsito livre entre uma etnografia literária e literatura etnográfica. Isso porque a produção literária escora-se no 
mesmo projeto analítico de desvelar a história, os modos e os costumes da vida maranhense. Entendamos bem, desvelar as particularidades daquela região que junto à Bahia congrega os "focos originários" da nacionalidade brasileira. Os contos coligidos nesta investigação permitem acompanhar o amadurecimento desse projeto.

Entre 1900 e 1902, o autor publica em Os Novos os seguintes contos: Perjúrio, Abnegação, Uma Scena Antiga e Tema Eterno. Esses trabalhos, também ignorados até o presente, ainda não possuem o acento regionalista que caracterizaria fortemente a literatura de Astolfo Marques. Entretanto, o interesse histórico já comparece nos contos Abnegação e Uma Scena Antiga. O primeiro narra o infortúnio e morte de dois soldados maranhenses, pai e filho, convocados a combater o arraial de Canudos chefiado por Antonio Conselheiro. O velho recebe a notícia de que perdera a mulher e precisa voltar à São Luís para honrar sua casa enlutada. Desiste a meio caminho e retorna passando a frente do batalhão republicano e termina, por engano, cravado por balas do seu próprio exército. O ímpeto do jovem para salvar o pai o torna presa fácil para os jagunços, estes o alvejam com o velho ainda nos seus braços.

Uma Scena Antiga, também é a história de uma morte, pretende registrar a degradação moral da sociedade brasileira no período escravocrata, uma década antes do conto ser publicado. Quincas, o filho varão de Joaquim Pereira, deu pela falta de um escravo, Marcos, na senzala da fazenda. Montou uma expedição de dez homens para ir caçá-lo e dentro de três horas ele estava amarrado diante de seus pés. Era sábado, a família recebia visitas no alpendre, e a cena passou-se na frente de todos os convidados que sorriam do incidente. Interrogado pelo sumiço, o preto respondeu que esquecera o cesto no caminho da roça e teve de retornar para pegá-lo. O patrão não acredita e autoriza duas fortes chicotadas. Marcos desaba no chão e Quincas ordena que o batam até que o escravo se levante. O preto aparentemente desmaia e seu corpo é conduzido até uma tina com água, cachaça e sal, mas não se ouviu nenhum gemido. Marcos já estava morto. No outro dia, aniversário da filha de Joaquim Pereira, a família comemorou os doze anos da pequena lendo perante os convidados a carta de alforria do escravo assassinado.

Esses dois pequenos contos expressam uma característica que percorrerá praticamente toda obra de Astolfo Marques: o interesse pelo valor cultural da história maranhense e a cultura popular de uma maneira geral aparecem marcados pelas relações de poder na qual as personagens estão implicadas. Perspectiva sob a qual o horizonte regionalista desta literatura consegue ultrapassar a estética do pitoresco, uma vez que toda especificidade local surge sob influxo anônimo do tempo. 
Tudo indica que Astolfo Marques, ainda na primeira metade da década de 1910, considerou a maioria desses contos publicados em Os Novos entre 1900 e 1902 tentativas de principiante. Esses trabalhos foram sumariamente excluídos de sua antologia de estréia $A$ Vida Maranhense (1905). Naquela época era praxe das tipografias publicar na contracapa dos livros uma lista dos trabalhos que estavam em preparação ou já se encontravam no prelo. Em nenhuma dessas referências, encontramos qualquer menção à iniciativa de reunir numa obra os contos produzidos nesses primeiros três anos de Os Novos. Fato que reforça a hipótese de estarmos abordando um momento no qual a carreira literária do autor ainda estivesse indefinida.

Nesse sentido, é interessante analisar os estudos biográficos realizados por Astolfo Marques, outra linha de força da sua produção intelectual. Vimos que dentre os cinco trabalhos citados no Boletim Comemorativo referentes ao periódico Os Novos, três deles versavam sobre a vida de maranhenses ilustres. São dois trabalhos sobre Gonçalves Dias e um perfil sobre Damasceno Ferreira, sendo que este último não foi localizado nesta investigação.

Um problema salta aos olhos quando analisamos o perfil de Gonçalves Dias inserido na coluna Vultos Maranhenses em novembro de 1900. Ao contrário do artigo Gonçalves Dias e Sua Personalidade Literária, publicado quatro anos mais tarde, o texto não está assinado pelo autor. Mais confuso ainda: logo abaixo da coluna Vultos Maranhenses, encontra-se outro pequeno artigo de título Gonçalves Dias, este sim, assinado por Astolfo Marques. Entretanto, este segundo trabalho não é sequer mencionado no Boletim Comemorativo.

Sem mais delongas sobre as deficiências metodológicas do nosso instrumento de pesquisa a questão é: por que a autoria da coluna Vultos Maranhenses é atribuída a Astolfo Marques sem que exista qualquer traço evidente do mesmo? Por que este texto foi anotado enquanto que justamente o artigo que leva seu nome estranhamente descartado? Acredito que este procedimento se deve à importância conferida ao conjunto de estudos de título Apuntos Bio-bibliográficos que o autor veio a publicar, desde 1901, na coluna Os Escritores Maranhenses, do periódico ilustrado Revista do Norte. Tratavam-se de curtos perfis biográficos destinados a compor um livro de título Seleta Maranhense, reunindo informações sobre os principais intelectuais da região com vulto na história nacional. Nas palavras de Fran Paxeco:

A Oficina dos Novos, que se fundara a 28 de Julho de 1900, e a cuja incorporação tivemos o prazer de assistir, assumira o compromisso de zelar pela fama dos homens que engrandeceram, intelectualmente, o Maranhão. Existia o Panteon, de Antonio Henriques Leal. Mas essa obra 
tornara-se inacessível à leitura, pela sua rarêza. Carecia-se, além disso, de continuá-la pra que os sucessores daquela pleiada os não vitimasse a mesma amnésia. Henriques Leal, benemérit, poupara-os tamanha injustiça dos pôsteres.

E o Raul, armando-se duma paciência estóica, principiou a catar nos jornais, nas revistas,

nos estudos biográficos, nos dicionários bibliográficos, os subsídios de que precisava pros seus rápidos apuntos, primeiro insertos na Revista do Norte e após enfeixados numa volumosa Seleta Maranhense. Nessa ingrata faina, gastou muitos anos, corrigindo erros ou deficiências de Sacramento Blake e outros autores, consultando parentes e condiscípulos dos literatos de que tratava, pra que o livro saísse tão completo quanto possível, sob o prisma bio-bibliográfico (PAXECO, 1919, p. 78).

Diferente dos pesquisadores que prepararam O Boletim Comemorativo, o cônsul português cita apenas A Revista do Norte quando se refere aos estudos biográficos de Astolfo Marques. Entretanto, quando se compara o artigo sobre Gonçalves Dias em Os Novos com aqueles publicados na Revista do Norte, observamos a mesma estrutura textual: uma biografia breve sobre a trajetória do autor, os postos de prestígio que o mesmo galgou na vida pública, seguida da obra completa do homenageado.

Se os pesquisadores do Boletim têm razão ao atribuírem a Astolfo Marques a autoria do texto sobre Gonçalves Dias, algo que também considero provável, surge mais um problema: o citado artigo não é o único a ser apresentado na coluna Vultos Maranhenses. Nesta investigação foram localizados, no total, sete artigos apresentados na referida coluna: 1) Nina Rodrigues, 25/09/1900; 2) Cesar Marques 28/10/1900; 3) Gonçalves Dias, 03/11/1900; 4) Souza Andrade (Sousândrade), 30/11/1900; 5) João Deus do Rego, 28/02/1901; 6) Dunshee de Abranches, 13/05/1901; 7) João Antonio de Freitas, 15/08/1901. Nenhuma das colunas é assinada por qualquer um dos membros da Oficina dos Novos. Isso porque os artigos para Vultos Maranhenses foram concebidos enquanto um compromisso institucional para com a memória intelectual maranhense. Afirmam os editores na introdução do verbete Nina Rodrigues:

Cumprindo o que prometemos no primeiro número deste periódico, encetamos hoje o estudo biográfico-crítico dos nossos homens ilustres que pela maior parte são desconhecidos aqui. Começaremos pelo vulto do ilustrado Dr. Raimundo Nina Rodrigues um dos médicos mais notáveis do Brasil Moderno.

Para este projeto, a Oficina pretendia resgatar a memória dos principais intelectuais maranhenses do passado, assim como divulgar o trabalho dos que no presente, embora consagrados, eram pouco conhecidos em sua terra. Esses "estudos biográficoscríticos", além de divulgar o nome de seus "vultos" também ambicionava, em alguns casos, rever a posição dos escritores maranhenses da história da literatura brasileira. É o caso de Joaquim de Souza Andrade, mais conhecido como Sousândrade. Após descrever a trajetória do autor de $O$ Guesa, o colunista lança a crítica: 
Falando de Souza Andrade, que forma ao lado de Velho da Silva, Corrêa de Almeida, Juvenal Galeno, Eunapio Deiró, Luiz Delfino, Machado de Assis e outros patriarcas nacionais, na memória do Livro do Centenário, o Sr. José Veríssimo adjetiva-o - “o misterioso poeta de O Guesa errante. Bom seria que o ilustre crítico se desse ao trabalho de ler o Guesa, edição de Londres, produzindo sobre ele o estudo a que tem direito o maior dos poemas brasileiros. Nele encontrará o Sr. José Veríssimo numerosas passagens que lhe façam recordar o paralelo do Faust e do Child Harold.

É tempo de fazer justiça ao grande poeta.

A "justiça ao grande poeta" e o "estudo a que tem direito o maior dos poemas brasileiros" tiveram que esperar a célebre Revisão de Sousândrade, organizada pelos poetas concretistas Augusto e Haroldo de Campos, publicada em 1964. O excerto acima ilustra bem o que se entende por "crítico" nesses estudos biográficos: uma reconsideração do status intelectual do biografado. Não se dirige qualquer crítica à obra dos “Vultos Maranhenses”, elas são simplesmente listadas como prova de dedicação ao conhecimento, estão ali para serem consagradas, a crítica só comparece quando o prestígio do biografado, da tradição intelectual maranhense, se encontra ameaçada seja pelos acertos ou erros da crítica.

É muito provável que as colunas de Vultos Maranhenses tenham sido escritas por Astolfo Marques ou que mesmo no caso de poderem ter contado com a colaboração de diversos integrantes da Oficina, o autor tenha sido um dos principais colunistas. O trabalho cotidiano na Biblioteca Pública o colocava em contato direto com as referências bibliográficas capazes de subsidiar esses estudos biográficos. Além disso, é interessante notar a relação temporal entre término da coluna Vultos em Os Novos e o início da coluna Escritores Maranhenses assinada por Astolfo Marques, na Revisa do Norte. O último estudo biográficocrítico veio a lume no periódico da Oficina dia 15 de Agosto de 1901 e o primeiro dos Apuntos Bio-bibliográfico $1^{\circ}$ de novembro do mesmo ano. Depois disso, a Oficina não mais publicou séries de resenhas biográficas e, quando em 1903 abriu exceção para homenagear Antonio Lobo, tratava-se de um "apunto" do próprio Astolfo Marques, informando a finalidade do artigo através da indicação Da Antologia Maranhense.

Estas informações reforçam a hipótese de que o autor tenha iniciado em Os Novos a publicação de algumas resenhas biográficas, entretanto, amadurecido a idéia de publicar um livro dedicado a personalidades do mundo intelectual e político maranhense a partir de sua colaboração na Revista do Norte. Este periódico constituiu-se no principal órgão de divulgação da literatura produzida no Maranhão, durante a primeira década do século $\mathrm{XX}$, e teve grande impacto na carreira literária de Astolfo Marques. Uma das primeiras notas publicitárias da revista, publicada simultaneamente nos jornais A Pacotilha e Diário do Maranhão, revela um pouco do projeto editorial do magazine ilustrado: 
Aparecerá invariavelmente nos dias 01 e 15 de cada mês, em 8 a 15 páginas de ilustração e de texto, impressas em papel superior e colaboradoras pelos principais escritores nacionais e estrangeiros. Cada número será acompanhado de dois suplementos, consistindo uma na reprodução de uma gravura celebre ou de um trecho de musica e o outro num romance, sempre inédito, em tiragem, formatos e paginação especiais, constituindo assim um volume a parte da Revista. Em cada ano serão publicados, pelo menos, dois desses romances. A "Revista do Norte" registrará sempre, pela palavra e pela imagem tudo o que de mais importante ocorrer nas múltiplas manifestações da vida brasileira e, com especialidade, na dos Estados do Norte da Republica. Terá um correspondente especial em Paris, em Lisboa e no Rio de Janeiro, incumbido de remeter mensalmente uma crônica dos principais acontecimentos artísticos e literários. Consagrará uma seção especial, a cargo de uma distinta escritora portuguesa, as questões de moda e de economia domestica. Numa outra seção intitulada "o movimento bibliográfico", conservará os seus leitores informados do movimentos das livrarias do Brasil, de Portugal e dos outros países da Europa e da América, dando a lista das mais importantes publicações, acompanhadas das indicações de preços e nome do editor.

O $1^{\circ}$ Numero da revista trará entre outras, diversas gravuras, das festas com que foi entre nós recebido o novo Bispo da Diocese, d. Antonio Xisto Albano. (A Pacotilha 17-07-1901).

Tanto entusiasmo e esperança em relação ao novo empreendimento possuía alguma materialidade em termos de adesão da elite letrada, haja vista o número declarado de assinantes: “(...) logo ao sair do nascedouro, registra já perto de mil assinaturas, só nesta capital, que muitos crêem morta para as coisas espirituais, mas que constantemente apresenta flagrantes testemunhos de seu amor pelas letras" (A Pacotilha, 10 de Agosto de 1901). Em que pese o marketing publicitário próprio dos que desejam vender a revista e ampliar com o isso o público leitor, não se pode desconsiderar o patamar elevado a que se dispôs o grupo em termos de vendagem dos seus exemplares. A expectativa era tão grande, porque a revista, embora sediada em São Luís, estampa desde o título a intenção de ultrapassar as fronteiras do Maranhão: "Muitas pessoas do interior do estado, presentemente nesta capital, acorreram a inscrever-se no respectivo caderno dos assinantes do Pará e Amazonas, ao saberem do início da revista pelas informações dos jornais (...)" (A Pacotilha, 14 de Agosto de 1901).

Embora o anúncio da publicação tenha saído logo no mês de julho, o primeiro número só circulou para o público de assinantes em Setembro. A Revista do Norte estava sob coordenação de Antonio Lobo e gerenciamento e direção artística de Alfredo Teixeira, com o corpo editorial formado pela empresa Gaspar Teixeira \& Irmãos. O projeto editorial era conceber um quinzenário especializado em literatura e arte que sintonizasse a movimentação intelectual maranhense com o que de melhor ocorria na literatura brasileira e mundial. Entretanto, o principal interesse da publicação era registrar a vida literária do norte brasileiro, notadamente, os estados do Pará, Amazonas, Maranhão e Piauí.

Em outras palavras: tratava-se de um órgão de divulgação que visava conectar os intelectuais e as instituições dedicadas à cultura erudita no Norte do país. Havia um fluxo intenso de políticos, literatos e jornalistas nesta região que compunha o antigo estado colonial 
Maranhão e Grão-Pará. Clodoaldo Freitas, um dos principais intelectuais piauienses do período, conta entre os fundadores da Academia Maranhense de Letras. Uma das descobertas desta investigação é que o próprio Astolfo Marques, sob o pseudônimo de Flávio Reimar Jr, ao que tudo indica, era o titular da coluna Crônica Maranhense publicada no jornal paraense Folha do Norte. O intelectual português Fran Paxeco, também fundador da Academia Maranhense de Letras, antes de se estabelecer no Maranhão, viveu em Manaus e em Belém, onde colaborou em diversos cotidianos e morreu pertencente às Academias de Letras do Maranhão e do Piauí, Instituto Histórico Geográfico do Pará e Associação de Imprensa do Amazonas.

Esses dados permitem evidenciar a hipótese da existência de um sistema literário setentrional brasileiro, com temáticas específicas, mecanismos de consagração particulares, veículos de comunicação, instituições culturais próprias e gozando de relativa autonomia frente à produção intelectual realizada do sul do país. Note-se que um dos principais esforços de Antonio Lobo, nos primeiros meses de publicação do quinzenário, fora divulgar pessoalmente a existência e os objetivos da revista nos estados do Pará e do Amazonas. O jornal A Pacotilha transcreveu para os leitores maranhenses a acolhida entusiasta do quinzenário em Manaus:

Abaixo transcreveremos as palavras com que a imprensa do amazonas recebeu esta bela publicação maranhense:

"Editado ao maranhão, debaixo da sabia direção do nosso inteligente confrade Antônio Lobo, atualmente. Entre nos, saiu a lume esta nova revista ilustrada de literatura e de arte, seguramente a mais completa e elegante que se tem publicado no Brasil.

Além de no sumario do 1 número, que temos presente, figurarem nomes de escritores sobejadamente conhecidos no nosso meio literário, as magníficas photogravuras que ilustram as sua paginas recomendam-se não só por sua nitidez como por serem executadas no próprio estado, onde a referida revisa sai a luz.

Acompanham cada numero da publicação a que nos referimos uma folha de oito paginas de um romance, e ainda uma bela fotogravura impressa num esplêndido papel coucke.

Por todos os títulos recomendável se torna a revista em questão.

"Do comercio do Amazonas"

É com máximo prazer que noticiamos o recebimento de "A Revista do Norte”, do Maranhão, publicação quinzenal ilustrada de literatura e arte.

É seu diretor o Sr. Antonio lobo, ora hospedado no Hotel Cassina.

A revista, é editada pelos Srs. Gaspar Teixeira \& irmãos, e é um verdadeiro primor, que honra as letras nacionais.

As gravuras nítidas rivalizando com as figuras européias. A colaboração magnífica e seleta.

"A revista do norte estamos certos, fará a aceitação que merece o público amazonense".

De o "Globo"

Recebemos ontem a agradável visita d "A revista do norte", excelente periódico literário que se publica no maranhão.

O novel paladino vem cheio de riquíssima colaboração firmada pelas mais fulgurantes penas do meio intelectual do Maranhão.

"Do Amazonas"

O senhor Antonio Lobo, que atualmente, é hospede, veio ontem a nossa redação e deixou-nos um exemplar do primeiro número da revista do norte, que acaba de aparecer no estado do Maranhão.

É bem feita, correta na aparente material e oferece variada leitura. 
"D' A Federação"

O numero de "A revista", que devera ser distribuído a 1 do vindouro, já está no prelo. Traz ótimas gravuras, entre elas o retrato de Sienkiwig no seu gabinete de trabalho.

O suplemento consiste na reprodução de um belíssimo quadro, reproduzindo a cena do circo romano, do Quo Vadis? (A pacotilha, 26 de setembro de 1901, p.1).

A extensa matéria ressalta os diferentes jornais amazonenses que deram atenção $A$ Revista do Norte e a passagem do seu diretor por Manaus. A viagem servia ao mesmo tempo para conquistar público de assinantes em todo norte brasileiro além de estreitar as relações com os intelectuais dos demais Estados nortistas. Nas páginas do quinzenário encontramos a colaboração de diversos literatos da região. As fotogravuras, objeto de intensos elogios da crítica e parte significativa da revista, mesclavam imagens de políticos proeminentes do norte brasileiro ou de figuras ilustres que visitavam o Maranhão, como de paisagens urbanísticas que revelavam o desenvolvimento da região, como pontes, estradas e ferrovias recém construídas. Os chamados "tipos populares" daquela região também serviam de inspiração artística, que fotografava as feições de trabalhadores nortistas, bem como suas famílias e formas de habitação. 


\section{A Revista do Norte}

\section{ANNo I Maranhão, 1 de Setembro de 1901 NuM |}

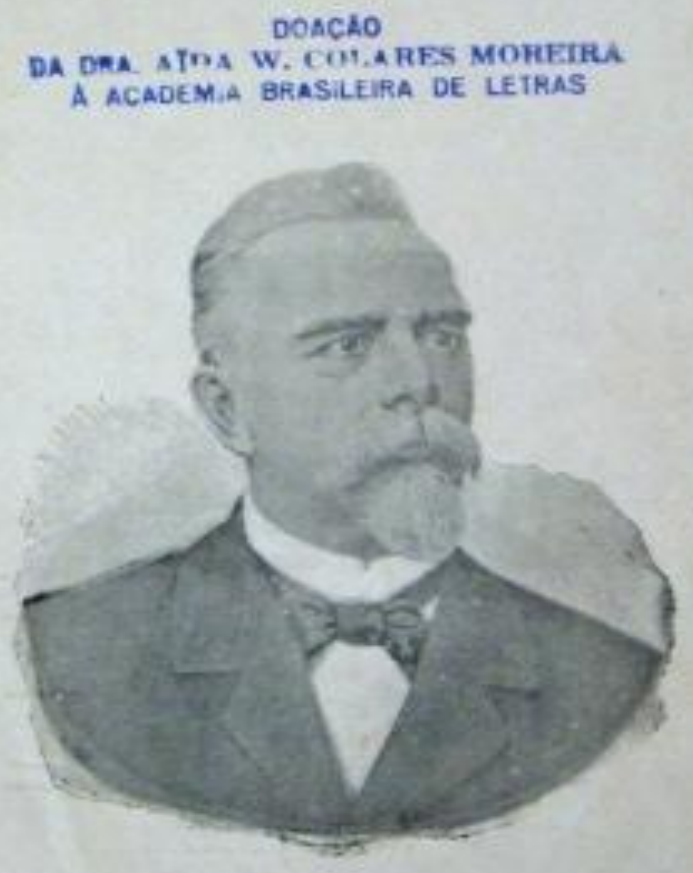

\section{Dr. Manod Perraz de Campos \$alles}

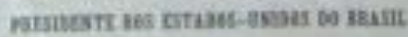

A Revista do Norte, $1^{\circ}$ de Setembro de 1904

Capa da $1^{a}$ edição da Revista do Norte. A foto do presidente Campos Salles reafirma o compromisso republicano da geração dos Novos Atenienses. 


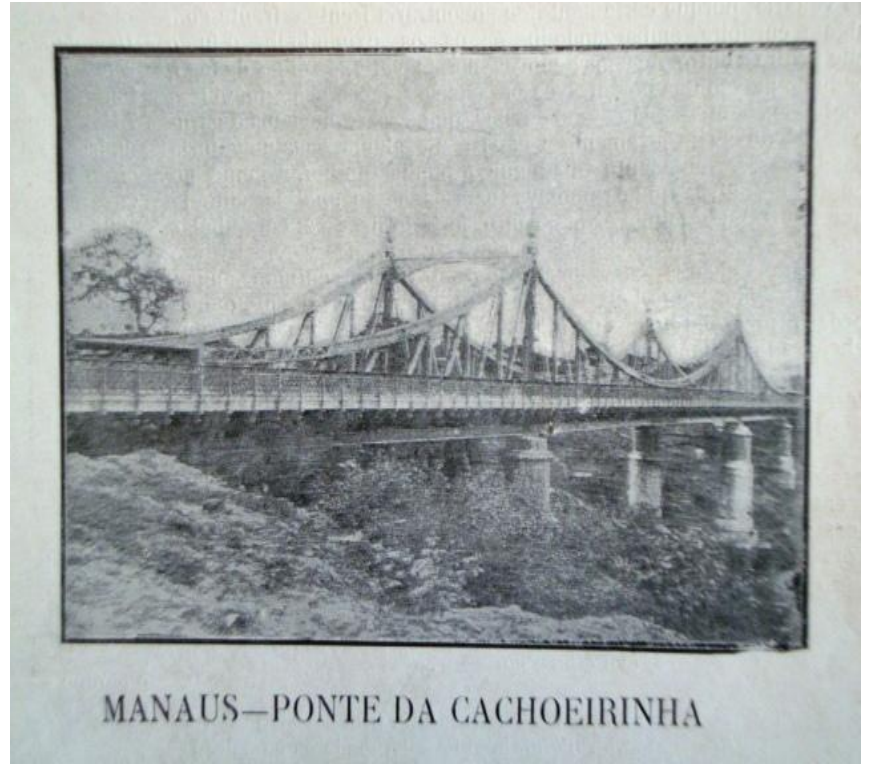

A Revista do Norte, 16 de Setembro de 1901

O periódico investia nas imagens de progresso e desenvolvimento da região. Pontes, ferrovias, estradas eram gravuras preferenciais, denotando os anseios de modernidade e integração nacional.

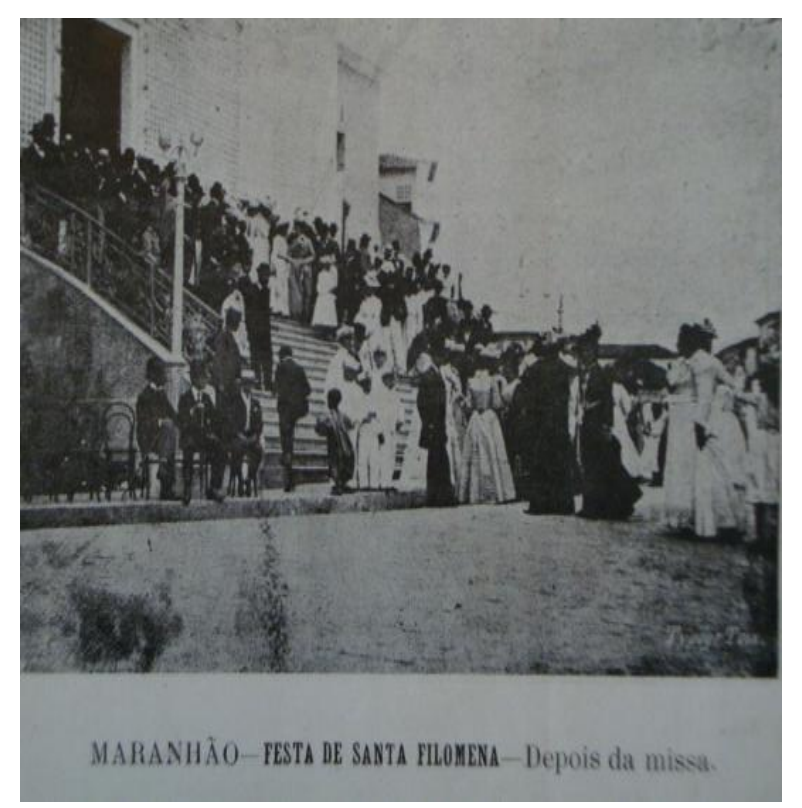

A Revista do Norte, $1^{\circ}$ de Outubro de 1902

As festas tradicionais do Maranhão tornam-se aos poucos objeto constante de reflexão. Astolfo Marques será um dos principais literatos de sua geração a desenvolver um projeto intelectual em que tais manifestações constituem o tema central.

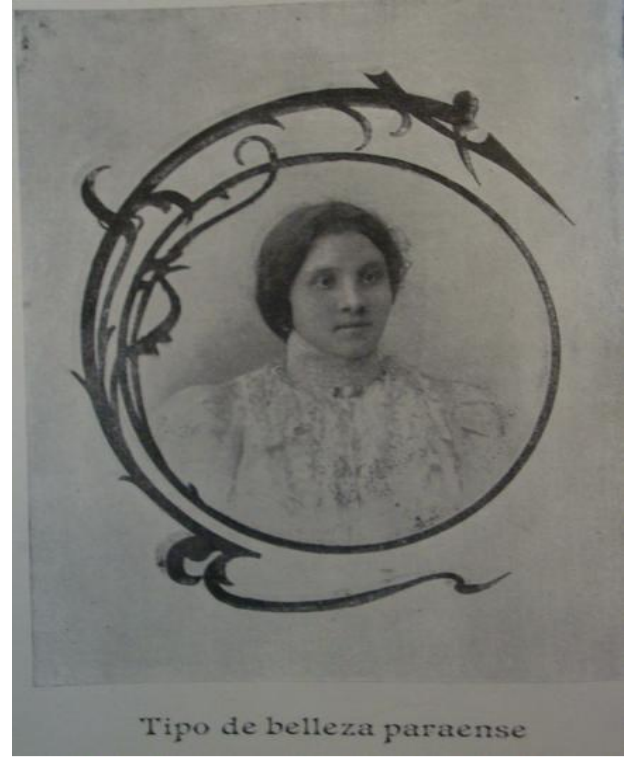

A Revista do Norte, 16 de Novembro de 1901

A busca de uma identidade cultural nortista é expressa na gravura a partir da elaboração de um ideário regional de beleza, em que se sobressai um modelo singular de mestiçagem baseado no português e no indígena.

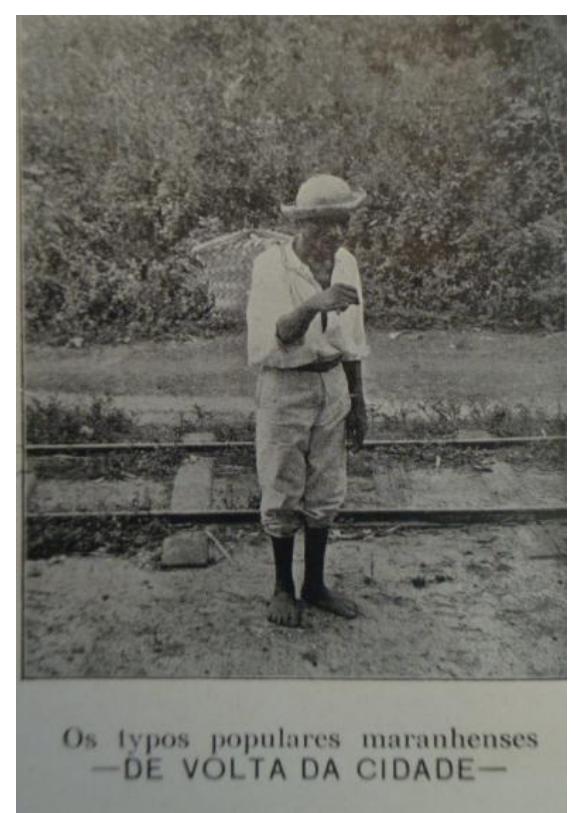

A Revista do Norte, 01 de Setembro de 1902

A indagação sobre a identidade cultural do país é obrigada a enfrentar uma personagem: o povo. Ele aparece no seu "devido lugar"degradado "naturalmente" pelas condições de trabalho; $O$ povo é também parte da paisagem. 
A maior parte da revista era dedicada à prosa, poesia, crítica literária e às traduções de romances ainda inéditos no Brasil. Antonio Lobo, sócio honorário da Oficina dos Novos também acolheu os trabalhos de jovens literatos maranhenses como João Quadros, Viriato Corrêa, Francisco Serra e Astolfo Marques. Entretanto, o prestígio da revista se fazia a custas da beleza do material impresso, a assídua colaboração portuguesa e o apoio dos eminentes escritores maranhenses residentes na capital do país. Arthur Azevedo encarregouse de fazer a propaganda da revista no jornal carioca O País (28 de Julho de 1901) e o irmão Aluízio cedeu ao quinto número do quinzenário, em primeira mão, trechos de seu último trabalho A Condessa Vesper (A Pacotilha, 4 de Novembro de 1901).

Não espanta que um empreendimento tão arrojado exercesse tamanha influência na carreira literária do jovem Raul. O Boletim Comemorativo lista vinte trabalhos do autor publicados no quinzenário. São dez resenhas biográficas, duas traduções e oito contos (Ver ANEXO). A parte mais significativa da colaboração do autor na Revista do Norte são os seus chamados Apuntos Bio-bibliográficos. A partir desses trabalhos ganharia corpo a idéia de reuni-los numa Seleta Maranhense, projeto com o qual Astolfo Marques constituiria-se para seus pares enquanto um pesquisador sério, trabalhador e talentoso. Afirma Fran Paxeco:

Foi este o seu maior e melhor esforço, que substancia um preciosíssimo repositório biobibliográfico dos "notáveis" do Maranhão. (...) A soma de pesquisas reunidas na Seleta é impresumível, pois ninguém mais, ousamos afirmá-lo, será capaz de conseguir o que aquele tenaz "garimpeiro" conseguiu. Todos os que se interessam pelo bom nome desta terra devem num impulso altruístico, diligenciar descobrir o paradeiro desses insubstituíveis manuscritos, e muito especialmente o da Seleta que vale uma fortuna (1919, p. 79).

A importância do testemunho de Fran Paxeco é elucidar a partir de que tipo de produção intelectual o autor foi conquistando pouco a pouco sua projeção no meio literário maranhense. Interessa-nos menos a qualidade real ou suposta da malograda Seleta e sim o fato de que esta fora considerada "insubstituível" e de "valor impresumível" a sua época, um trabalho que ninguém mais seria capaz de realizar. Desse modo, o trabalho biográfico constituiu a principal fonte de prestígio intelectual para Astolfo Marques. Antonio Lobo considerava a Seleta "o guia mais completo e seguro que desejar se possa, para o estudo da vida literária maranhense da Atenas Brasileira" ([1909], 2008, p.118). Em outras palavras: essas pesquisas tornaram o trabalho do escritor negro uma peça chave para a legitimação simbólica da intelectualidade maranhense. É significativo que mais de uma década após a morte do autor, José do Nascimento Moraes (1882-1958), primeiro presidente da Oficina dos Novos, ainda lamentava a perda da Seleta e seu significado para a educação cívica da 
juventude:

Nosso inesquecível conterrâneo Astolfo Marques, Jornalista e "conteur", estudioso de tudo o que dizia a respeito à nossa terra, colheu escrupulosamente, devotadamente, durante alguns anos de sua atividade mental, copioso cabedal para produzir sobre homens, fatos e coisas maranhenses, um trabalho que estivesse à altura de nossa educação cívica.

Desse cabedal tirou ele o necessário para uma "Seleta Maranhense" que, de fato, organizou, com muito método, de acordo com as normas pedagógicas. Faltava-lhes apenas o batismo do prelo. E quando estavam todos os intelectuais maranhenses que tiveram a satisfação de ler o trabalho, a seu convite, ansiosos de o ver publicado, eis que os autógrafos desaparecem, sem que se pudesse saber onde nem como.

Infelizmente só se deu com esse lamentável fato, dias depois do seu falecimento, quando seus amigos e companheiros de ideais literários o procuravam para lhe publicidade, pois de tudo o que deixou suas locubrações era justamente o que a todos se afiguravam capaz de prestar a seus filhos um socorro econômico de que tanto, então, precisavam.

Depois de Astolfo Marques, ninguém pensou mais em repetir a tentativa, o que é, aliás, uma falta de que não podem se justificar os intelectuais maranhenses (MORAES: [1931] 1982: 327).

Essas palavras de saudade e reconhecimento intelectual ratificam que o prestígio de Astolfo Marques nas letras regionais deve sobremaneira aos perfis biográficos que começou a publicar na Revista do Norte. Vale destacar, que se na Oficina dos Novos o patrono de seu assento era Celso Magalhães, quando fundou a Academia Maranhense de Letras “escolheu" como patrono o biógrafo Antonio Henriques Leal ${ }^{18}$. Mudança que nos revela que as condições simbólicas de consagração do autor estavam diretamente vinculadas à Seleta Maranhense, ao seu trabalho de pesquisador da vida literária local e em menor grau a sua produção ficcional.

O Boletim Comemorativo cita, a partir da data 16 de setembro de 1902, a existência de onze perfis biográficos publicados na Revista do Norte. Com exceção do texto Celso Magalhães todos os outros foram publicados na coluna Escritores Maranhenses enquanto Apuntos Bio-bibliográficos. Desse modo, ignora os dez trabalhos anteriores: 1) Manuel Odorico Mendes 01/11/1901; 2) Antonio Corte Lacerda e Martinus Hoyer, 16/11/1901; 3) Francisco Sotero dos Reis, 01/02/1902; 4) Cândido Mendes de Almeida, 01/04/1902; 5) Antonio Gonçalves Dias, 16/04/1901 e 01/05/1902 6) Frederico José Correa, 01/07/1902; 7) Antonio Henriques Leal, 16/07/1902; 8) Antonio Marques Rodrigues, 01/08/1902.

\footnotetext{
${ }^{18}$ Antônio Henriques Leal (MA/1828 - RJ/1885) foi patrônomo da cadeira n. 10 da Academia Maranhense de Letras. Originário de família rural abastada no interior do Maranhão, migrou para São Luís e Rio de Janeiro, nesta última cidade estudou medicina. Colaborou na imprensa ludovicense e carioca, além de publicar os seguintes livros: A província do Maranhão (1862); Pantheon maranhense (1873-5); Apontamentos para a história dos Jesuítas no Brasil (1874). Destaca-se ainda sua inserção no Instituto Histórico Geográfico. Na política, foi vereador (1865), tornando-se presidente da Câmara, e deputado provincial (1866), ambos mandatos exercidos pelo partido liberal (BORRALHO, 2009).
} 
Esses artigos possuem a mesma estrutura e funcionalidade daqueles apresentados em Vultos Maranhenses. É o mesmo trabalho de "erguer bustos" para uma geração sedenta de consagração e referenciais que confirmem a grandeza local mediante a pouquíssima relevância de São Luís e das demais capitais nortistas para eixo o dinâmico da vida cultural brasileira, fato radicalizado com o modernismo paulista dos anos 1920. A única diferença significativa entre Vultos e os Apuntos é que após a apresentação da síntese biográfica seguida da bibliografia completa do homenageado, o autor apresenta a bibliografia consultada para escrever o perfil. Assim, ficamos conhecendo um pouco das leituras de Astolfo Marques.

Ao longo dos quinze primeiros perfis publicados na Revista do Norte o autor menciona como obras consultadas: a) Obras Completas de João Francisco Lisboa b) Dicionário Bibliográfico Brasileiro de Sacramento Blake c) Curso de Literatura Portuguesa e Brasileira de Francisco Sotero dos Reis d) Panteon Maranhense de Antonio Henriques Leal e) Revista Trimestral do Instituto Histórico Geográfico f) Estudos de Literatura de José Veríssimo g) El Brasil Intelectual de Garcia Mérou h) Crítica e Polêmica de Frota Pessoa i) Livro do Centenário - A Imprensa, memória por José Veríssimo j) Dicionário Histórico e Geográfico da Província do Maranhão de Cesar Marques 1) Livro do Centenário - A Literatura, memória por Sílvio Romero m) Escritos e Discursos Literários de Joaquim Nabuco n) Sessenta Anos de Jornalismo - A Imprensa do Maranhão de Joaquim Serra (Ignotus).

Além de mencionar os textos com que se baseava para construir suas resenhas bibliográficas, Astolfo Marques procurava mobilizar autoridade intelectual para seus trabalhos recorrendo aos familiares dos biografados e, quando possível, ao testemunho dos próprios para referendar a pesquisa ${ }^{19}$. A coluna dedicada a Sousândrade contém a seguinte observação: "Foram-me todas estas notas prestadas pelo próprio bio-bibliografado em agosto de 1901".

Embora tenhamos enfatizado que a principal influência de A Revista do Norte na carreira literária de Astolfo Marques foi possibilitar um espaço de divulgação para a suas

\footnotetext{
${ }^{19}$ Neste sentido, para corrigir as informações de Sacramento Blake acerca de Frederico José Corrêa afirma o autor: "Para estes Apuntos, além do livro Sessenta Anos de Jornalismo - A Imprensa do Maranhão (18201860), de Joaquim Serra (Ignotus) foram-me ministradas todas as notas pelo ilustre filho de Frederico José Correa, o Sr, José Augusto Corrêa, delegado fiscal do Tesouro Nacional neste Estado, autor dos Estudinhos da língua portuguesa e outros opúsculos de grande utilidade e valor real, a quem consagro estas linhas de meus agradecimentos. O Dicionário Bibliográfico, do Sacramento Blake, está todo errado neste ponto." Note-se que os Apuntos serviam também para o autor estreitar relações com membros destacados da sociedade maranhense como o delegado fiscal do Tesouro Nacional.
} 
pesquisas biográfica acerca da intelectualidade maranhense, o quinzenário também parece ter tido muita influência na definição do seu estilo literário. Não apenas por ser um órgão especializado na região norte, mas também a partir da promoção de um evento que, acredito, mexeu positivamente com a auto-estima do jovem escritor. Quando folheamos seu romance de estréia A Vida Maranhense (1905) encontramos a seguinte indicação abaixo do conto $A$ Promessa: "2º Prêmio Francisco Guimarães, no Concurso Literário d'A Revista do Norte (1903)'. Trata-se de um concurso destinado aos jovens prosadores. Eis o edital:

Fica aberto, nas colunas d'A REVISTA DO NORTE, por espaço de quarenta dias, a contar de 1 de Agosto, um concurso literário entre os jovens prosadores maranhenses mediante as seguintes condições:

I As composições não poderão afastar-se do Maranhão, colhendo os seus temas ao período colonial ou na época atual.

II Só se admitem escritos em prosa, não podendo a sua extensão ficar aquém de vinte linhas, nem além de quarenta.

III O júri é composto de Machado de Assis, Arthur Azevedo e Reis de Carvalho, todos residentes no Rio. Os originais devem ser enviados para A REVISTA DO NORTE, a Fran Paxeco, vindo num sobrescrito a composição e noutro o nome do autor com o pseudônimo correspondente.

IV Os prêmios, doados pelo benemérito maranhense, Sr. Francisco Guimarães, domiciliado em Buenos Aires, constituirão no seguinte: $150 \$$ para o primeiro classificado, $100 \$$ para o segundo e $50 \$$ para o terceiro.

V O prazo do concurso encerra-se dia 10 de setembro, ao meio dia (A Revista do Norte, 01/09/1902).

Embora esse edital não seja o de 1903 e sim o do primeiro concurso, acredito que não houve mudanças significativas em sua estrutura de ano para outro. Para Astolfo, vencer uma competição avalizada por literatos notáveis, pertencentes à Academia Brasileira de Letras, como Machado Assis e Arthur Azevedo, ou mesmo, caso tenha havido mudanças na banca, referendado por eles, deve ter influenciado muito o jovem autor. Talvez tenha sido o estímulo necessário para afirmar a si próprio a viabilidade da carreira como escritor. Naquele momento, pela primeira vez, ele pode ver-se como um vitorioso entre seus pares na arte a que todos se dedicavam. Acredito que o concurso também tenha sido importante para definição do seu estilo. O autor teve motivos convincentes para acreditar que de fato a "vida maranhense" era um campo o qual ele conseguia apreciavelmente transformar em ficção.

Outro dado corrobora a hipótese de que o $2^{o}$ Concurso Literário Francisco Guimarães (1903) tenha sido um divisor de águas em sua carreira. Quando analisamos a contracapa do volume A Vida Maranhense (1905) encontra-se uma lista das obras que Astolfo Marques pensava em editar naquele momento: 1) A Vida Maranhense, contos, $2^{\mathrm{a}}$ serie (19041905), com a referência "a entrar no prelo"; 2) Seleta Maranhense (Edição do Estado do Maranhão) com a indicação "Idem"; 3) As Festas Populares Maranhenses, narrativa histórica com a nota "em preparação". 
Nos idos de 1905, o autor realmente não pensava mais em publicar os contos dos anos de 1900 e 1901. A série Tipos Populares também se encerrara em 1902. Aquele tempo já tinha passado. O trabalho etnográfico do autor se concentrava agora no livro Festas Populares. Mesmo em A Vida Maranhense somente dois contos datam de 1902, os outros se dividem entre 1903 e 1904. Minha hipótese é que o período de 1900-1903 marca a maturação intelectual de Astolfo Marques. O concurso literário veio para dar-lhe confiança de que podia seguir no caminho do conto regional, registrado em toda sua carreira. Mas faltava ainda um confronto necessário para a plena configuração de um estilo literário: o embate com o público. 


\section{O Escritor e a Crítica}

Um dos aspectos mais surpreendentes quando investigamos a recepção da obra ficcional de Astolfo Marques é que, ao contrário da insistência das análises póstumas sobre a pequenez intelectual da obra, nos deparamos, em geral, com críticas positivas em relação à qualidade artística de seu trabalho. $\mathrm{O}$ hiato entre as duas perspectivas, para além das mudanças nos juízos estéticos, deve-se em parte ao desconhecimento desse material. O Boletim Comemorativo ignora completamente a recepção intelectual do autor. Entretanto, as academias de letras, as iniciativas públicas de celebração de uma personalidade literária, interessam-se sobremaneira pela divulgação da crítica literária favorável a seus autores, uma vez que estas alimentam o status da tradição que vincula os chamados clássicos aos contemporâneos.

Os textos que perfazem a crítica literária de Astolfo Marques à sua época são fundamentais para aproximação sociológica do autor, pois nos permitem compreender os significados de sua prosa no interior da cultura erudita, constituem uma espécie de trabalho de tradução em que o autor é posicionado numa extensa rede de divisão social do trabalho.

\footnotetext{
Se a obra é mediadora entre o autor e o público, este é mediador entre o autor e a obra, na medida em que o autor só adquire plena consciência da obra quando ela lhe é mostrada através da reação de terceiros. Isto quer dizer que o público é condição para o autor conhecer a si próprio, pois esta revelação da obra é sua revelação. Sem o público, não haveria ponto de referência para o autor, cujo esforço se perderia caso não lhe correspondesse uma resposta, que é definição dele próprio (CANDIDO, 2006, p. 87-8 [grifos meus]).
}

Neste sentido, a investigação da crítica literária relativa à obra de Astolfo Marques nos permite objetivar um pouco de como sua plena consciência da obra lhe foi “mostrada por terceiros", ou seja, enfatizar o impacto da crítica na conformação de um estilo ao mesmo tempo indiscutivelmente pessoal e socialmente apreciável. Este aspecto é tanto mais importante se levarmos em consideração que estamos falamos de público leitor extremamente restrito. Resta dizer que, de acordo com o Congresso Interestadual de Ensino efetuado no Rio de Janeiro em 1921, computava-se para o Maranhão o percentual de $95 \%$ de analfabetos em idade escolar (PAXECO, 1923: 624). Dado que nos permite inferir que a relação de um autor com a crítica literária constituía parte significativa da sua relação com o público em geral. Observemos o modo como o jornal O Federalista preparava seu público leitor para o lançamento da obra A Vida Maranhense. No dia 26 de maio de 1905, o jornal publicou a seguinte nota: 
Exultem de prazer os amantes das letras. O Astolfo Marques, operoso e apreciado beletrista maranhense um dos intelectuais que não descansam e que não perdem ocasião de mais elevar o nome glorioso desta terra na literatura pátria, pretende em breve dar a luz publicidade de uma coleção de contos com o título que encima estas [linhas] e que será o $5^{\circ}$ volume da Biblioteca da Oficina dos Novos.

"A Vida Maranhense" que está sendo impresso na acreditada tipografia Frias, conterá 12 contos, dentre eles - "O batidinho", "A peste. (A opinião da Euzebia e As preces)". "Os dois herdeiros", "O domingo dos Maramaldos (cenas da vida devota). "A surpresa", "A promessa" ( $2^{\circ}$ prêmio literário d"“A Revista do Norte"). "O suplício da Ignacia", alguns publicados, outros inéditos e todos escritos entre 1902 e 1904.

O livro circulará simultaneamente em todos os Estados do norte no dia 20 de junho próximo.

Felicitando o distinto operário da Oficina dos Novos, damos parabéns ao público maranhense por esse interessante trabalho, que certamente despertará o máximo interesse, entre os que formam o nosso círculo literário (O Federalista, 26/05/1905).

A nota é deveras esclarecedora, pois revela o clima de expectativa que antecedeu a publicação da primeira obra de Astolfo Marques, seja devido à “distinção do autor” que não perde ocasiões de "elevar o nome glorioso desta terra na literatura pátria", seja devido ao clima de marasmo intelectual e os obstáculos a produção literária. A descrição do autor como um "incansável” é uma crítica àqueles que teriam cedido na tarefa de perpetuar a tradição literária local. O próprio fato de A Vida maranhense ser o sexto volume publicado pelo programa editorial Biblioteca da Oficina dos Novos já demarcava o sucesso do grupo literário, sendo o autor constituía um dos seus expoentes mais expressivos.

Outro dado relevante é que o livro seria lançado simultaneamente em todos os Estados do norte. Informação que reforça a hipótese que tem ganhado força ao longo dessas investigações: a existência de um sistema intelectual coerente entre os Estados do Maranhão, Pará, Piauí e Amazonas. Embora não tenha sido possível ampliar o escopo desta investigação para os jornais piauienses, paraenses e amazonenses, para acompanhar a recepção deste livro, é provável que o lançamento de A Vida Maranhense noutros estados nortistas valha-se das redes intelectuais construídas em torno da Revista do Norte.

O jornal Diário do Maranhão, na coluna Semanais, no dia 7 de junho, também fez honras ao escritor, anunciando com entusiasmo seu livro de estréia. Identificando-se apenas com o pseudônimo de Hernani, o crítico concentrou-se no significado da publicação para renovação do espírito literário local e as tendências estéticas que perfazem $A$ Vida Maranhense:

Numa época em que o spleen invade incautamente o nosso espírito destruindo paulatinamente, as nossas energias psíquicas, é já um alevantado esforço a pertinácia no cultivo das letras e esforço ainda maior a elaboração de um trabalho literário, mormente moldado nos costumes de um povo. Mais ainda do que o simples observar é ainda o perscrutar, afiançado a vista longe, numa agudeza de espírito para descrições de quadros e cenas e a este trabalho, que algo de preocupações dá, se entregou, devotamente, Astolfo Marques, tornando-se um acurado investigador e analista de tudo que lhe cabe em observação.

Subtil e perspicaz no apanhar ao vivo o que vê, numa obrigação religiosa, constante, Astolfo 
Marques tem já essa profundeza de vista própria dos psicólogos que tudo fotografam com fidelidade escrapulosa.

O psicologismo, que tem por mais ilustre representante Dostoievski é a escola mais moderna e que talvez mais prosélitos tenha.

O jovem autor d'A vida maranhense, porém, não deixou-se empolgar pelo psicologismo, dedicouse também ao naturalismo, filiando-se a escola que um crítico chamou - naturalismo-psicologista - que é representada por Catule Mendés e Eça de Queirós.

O livro que aparecerá brevemente, é uma resultante de estudos, ou antes de ensaios, de psicologia a que Astolfo Marques se tem entregue estes últimos tempos, com uma constância de forte e uma ânsia de saber insaciável, nas horas de labor furtadas ao tedium vitae de que nos fala o escritor francês Tardieu.

Como se deduz do título do novo livro, todo ele se ocupa de cenas da vida maranhense, descritas sem os arabescos da phantasia, mas trazendo em si impregnadas o cunho da naturalidade, sem o exagero da idéia e o trucidamento da forma que certamente dá todo valor à A Vida Maranhense.

Para Hernani, é preciso levar em conta o significado da publicação numa época em que soçobraram as forças para dar dignidade ao trabalho intelectual. Isso mesmo quando, observemos a reticência, trata-se de um livro "moldado nos costumes de um povo". É interessante que Astolfo Marques seja descrito aqui como um "acurado investigador e analista de tudo que lhe cabe em observação". Para o crítico, os contos de A Vida Maranhense são equivalentes a estudos científicos, ou seja, a literatura parece ser considerada tão apta quanto às chamadas ciências humanas para revelar os meandros da vida social. Daí os elogios a "essa profundeza de vista própria dos psicólogos" das cenas "fotografadas" na obra "sem os arabescos da phantasia".

Outro sucesso do livro nas palavras do crítico é sua independência estilística. $\mathrm{Na}$ verdade, a mescla de duas escolas literárias, naturalismo e o que chama psicologismo, sem que o autor cedesse aos vícios de forma de qualquer uma delas. Além disso, acrescenta o colunista: "o livro de estréia de Astolfo Marques tem a cor nativa, é todo nosso, nos pertence de alma e coração, acrescentando a isso o sabor da época em que foi escrito o que, indubitavelmente, torna o mesmo livro, por mais este título, deveras apreciável”. Enfim, uma crítica positiva, que retrata a expectativa do meio literário maranhense por um programa de publicação coerente com seus anseios de renovação literária.

Dias após estes anúncios festivos do primeiro livro de Astolfo Marques, A Pacotilha deu lugar à crítica da obra em sua primeira página. Sob o pseudônimo de Bento Villares, o colunista pretendeu desnudar quais as principais ambições literárias contidas em $A$ Vida Maranhense:

Costumo ler tudo o que escrevem os moços aqui da terra, e sempre me despertou atenção esse fato de não ver o nome de Astolfo debaixo de quatorze versos. Mas não é possível: ele há de ter publicado sonetos amorosos, pensava eu. E, encontrando-o, atirei-lhe esta pergunta: - Você nunca publicou versos? A resposta foi negativa.

O fato, porém, não fica aí. Dos seus artigos por mim lidos concluí que ele não se atitou à exploração desse exploradíssimo campo do amor, que muita gente boa já proclama esgotado. 
Propósito calculado e firme, ou questão de temperamento, a circunstância não é de somenos valor. A notícia de que ia aparecer $A$ Vida Maranhense veio reforçar, em mim, este juízo: o autor parecia estar possuído da intenção louvável de fazer obra duradoura e útil, estar mesmo convencido de que nosso viver de todo o dia tem muita galeria prima para se aproveitada, em substituição aos temas velhos e banais de livros que ninguém compra.

Com essas impressões pré-estabelecidas, lemos a primeira série de contos, agora publicada. E talvez porque era e é nosso desejo, lendo-o, vê-lo triunfar por completo, achamos que, ao menos quanto a este tomo, o título ficou muito amplo em relação ao conjunto do seu conteúdo. Ele prepara a expectativa do leitor para apreciação de verdadeiros costumes nossos, de onde ressalte a característica dominante de nossa índole, análise de feições e tendências, crítica de preconceitos arraigados, a fixação de tradições que não devem ser olvidadas, tudo isso, enfim, que poderia chamar a psicologia do meio, feita com arte e critério.

Astolfo Marques há de concordar em que a escolha dos assuntos, da qual depende a apresentação de certas figuras, é base essencial à realização do fim que o nome do livro pressupõe.

Se não me engano, teve o autor o intuito de chamar a esta coleção de Scenários Maranhenses, título certamente mais compatível com a natureza do seu trabalho, ao passo que, o por si adotado, obrigava-o de certo modo, obedecendo aos preceitos da arte, a fazer a obra mais sistemática, com vistas mais gerais.

Não falta ao livro cor local e, a não ser por essa divergência em que estamos, só podemos dizer bem do que há nele escrito (A Pacotilha, 26 de Junho de 1905).

Temos aqui um exemplo de crítica cordial. Note-se primeiro a intimidade entre o crítico e o escritor. O contato pessoal de Bento Villares com Astolfo Marques bem como o acesso do mesmo a quase todos os textos do escritor publicados anteriormente, inclusive o título com que autor pretendeu dar a sua sua coletânea e depois desistiu, revela que ambos faziam parte do mesmo círculo de convivência intelectual. Dado que esclarece um pouco das características da crítica literária maranhense: uma apresentação formal dos amigos elou inimigos a partir de um código erudito. Menos análise crítica e mais a defesa ou o ataque dos escritores estimados ou rivais. Observe-se que o crítico proclama seu desejo de ver o livro do companheiro "triunfar por completo". Exemplo radical de um meio literário "o escritor se habituou a produzir para públicos simpáticos, mas restritos, e a contar com a aprovação dos grupos dirigentes, igualmente reduzidos" (CANDIDO, 2006, p. 95).

Essa característica nos ajuda inferir um pouco mais sobre o impacto da crítica na conformação do estilo literário de Astolfo Marques. Observemos agora o exercício retórico de Bento Villares em ressaltar que o fato do escritor jamais ter se dedicado à poesia e ao tema "esgotado" do amor o convencera de que o mesmo estava

"possuído da intenção louvável de fazer obra duradoura e útil, estar mesmo convencido de que nosso viver de todo o dia tem muita galeria prima para se aproveitada, em substituição aos temas velhos e banais de livros que ninguém compra”. A pretensão do crítico ao aludir a um suposto movimento reflexivo é convencer o público leitor e o próprio Astolfo Marques de que há um projeto intelectual definido em A Vida Maranhense, a saber: tornar ficção a vida cotidiana do povo. Missão capaz de erigir uma obra duradoura, útil e lucrativa ao substituir os temas velhos banais de livros que ninguém compra. 
A única restrição de Bento Villares à obra é o título. A Vida Maranhense pareceulhe um anúncio grandiloqüente frente à matéria realmente tratada livro. Além do mais, faltou à obra um retrato dos "verdadeiros costumes nossos, de onde ressalte a característica dominante de nossa índole”. Mesmo sem esclarecer a termo em que reside a falsidade ou a incompletude do livro que não conseguiu tocar a característica dominante da índole maranhense, o crítico não deixa de destacar suas reservas "técnicas" quanto ao título da antologia.

O título do livro realmente criou celeuma na crítica. Nesse mesmo dia o jornal $O$ Federalista estampou no editorial de sua primeira página, sem assinatura, uma análise literária de A Vida Maranhense. Vejamos os primeiros parágrafos do texto:

É o título do novo trabalho de Astolfo Marques operário da "Oficina dos Novos".

Agradabilíssima a impressão que nos deixou a leitura deste livro. Percorremos-lhe as folhas, carinhosamente, bebendo na suavidade de sua linguagem doce, simples, despretensiosa, todo o encanto das cenas deliciosamente naturais que ele descreve. E pouco a pouco se vinha destacando, em primoroso relevo, o conceito que do operoso e inteligente literato formávamos de há muito, numa visão muito clara e confortadora do renascimento das letras nesta terra abençoada.

Não o desanimara a indiferença quase insuperável da publicação. Rebrilhava-lhe ao longe o ideal santo que seu espírito de moço debuxara e a tenacidade e o esforço e a inteligência triunfaram por fim.

Brindou o Estado que lhe foi berço com o seu adorável livrinho.

Há nos seus contos uma simplicidade que encanta. [ilegível] que o artista, dotado de observação fina e criteriosa leva a ponta aguda da análise aos fatos que lhe passaram aos olhos irrequietos e indagadores ( $O$ Federalista, 26/06/1905).

Uma crítica amistosa. Destaca características que serão notadas pelos críticos de Astolfo Marques ao longo de toda obra, ora em seu favor ora em seu demérito: 1) a suavidade da linguagem; 2) a simplicidade da forma; 3) a objetividade descritiva. Aspectos que irão nublar aos críticos mais simpáticos ao autor o que há criativo e invenção da realidade em sua prosa. O escritor negro parece ter logrado convencer a todos que seus trabalhos profundamente marcados pelas tendências regionalistas, naturalistas e realistas da literatura não continham a menor marca de sua subjetividade autoral, eram a cópia fiel do presente literário.

Note-se que a simpatia da crítica dirige-se também às circunstâncias do meio intelectual. O colunista destaca as dificuldades de publicação existentes no Maranhão e o esforço do autor para ver impressa sua obra. Assim, a mera edição de A Vida Maranhense é automaticamente um valor literário naquilo que possui de estímulo à produção intelectual. Essa a é âncora com que a crítica passa nos parágrafos finais do tom amistoso aos incômodos da condescendência: 
A PROMESSA é uma jóia literária. Pena é que o primoroso artista não lhe tenha mais acirradamente, burilado a forma graciosa.

Mas... não nos atraem as imperfeições do livro de Astolfo Marques. A outros [deixo] melindrosa tarefa.

Indigna-nos sobremaneira [o] escabichar de defeitos um livro onde ressaltam [belezas] numa profusão de flores atraentes em jardim bem cuidado. Não nos comprazendo em "meter os olhos debaixo das sombracelhas", como na frase de Vieira, e apontar os erros, e indicar senões, num carrancismo anacrônico de mestre escola de aldeia.

Impressiona-nos o lado belo das coisas: dos erros e dos descuidos desviamos os olhos. Que alguém mais austero e mais frio venha a apontá-los. Não nos tenta essa odiosa e triste tarefa.

Demais... para que? Bem poderia responder o artista com aquilo de Bocage: "Citas um verso mal, mil bons não citas"

Poderíamos, por exemplo, dizer que o título do livrinho, "A VIDA MARANHENSE" não nos parece muito adequado. $\mathrm{O}$ artista neste livro estudou apenas um aspecto da VIDA MARANHENSE. Não é apenas nos sapateados e nas festanças do populacho que se revela a vida dessa bela porção da pátria.

De que, porém, nos serviria isso! Compreende-se bem qual a intenção do primoroso artista... e é o quanto basta.

Não lhe hão de faltar censuras, possivelmente que a crítica de FACA E CALHAU lhe venha derramar muito fel n’alma. Não desanime, porém. Não lhe poderão empanar o brilho das composições as cergunchadas dos que estes sim incapazes do menor esforço, armam-se de rigor e severidade para com os que fazem alguma coisa (O Federalista, 26/06/1905).

Um final surpreendente. Ao invés de apontar os citados defeitos que garante existirem na obra, o crítico elabora uma retórica quixotesca para justificar sua própria omissão frente às "imperfeições" de A Vida Maranhense. Atitude, a seu ver, bem mais elevada do que “indicar senões num carrancismo anacrônico". Por outro lado, considera que na obra ressaltam bem mais qualidades do que problemas, além do que, afirma, o "escabichar defeitos" é uma atividade um tanto insensível e fútil já que não se abre para "o lado belo das coisas".

Tais justificativas dão à crítica uma interessante ambigüidade. O leitor poderia tomá-las tanto como uma defesa de um escritor estreante frente a um meio intelectual mesquinho dado a "meter os olhos debaixo da sombrancelha", como na forma de um ataque indireto ao autor. O colunista não poupou a Astolfo Marques a predestinação de críticas que venham a derramar-lhe muito "fel na alma" e desânimo. Mais do que isso: afirmou que se isentava de tal tarefa mais por estilo do que devido à impertinência da mesma. Afora o final consolador que procura desabilitar a crítica de "Faca e Calhau" por seu caráter moralmente improdutivo e não por equívocos de análise literária.

O esforço do crítico, por manter veladas suas censuras ao contista, soçobra apenas na análise do título da obra e devido sua franca tentativa de não ser confundido com aqueles que "incapazes do menor esforço, armam-se de rigor e severidade", podemos ter idéia do quanto lhe pareceu insuportável associar ao conteúdo da obra analisada à idéia de "vida de maranhense". Em suas palavras: "o título do livrinho, "A VIDA MARANHENSE” não nos 
parece muito adequado. O artista neste livro estudou apenas um aspecto da VIDA MARANHENSE. Não é apenas nos sapateados e nas festanças do populacho que se revela a vida dessa bela porção da pátria”.

Essas considerações merecem atenção. Na opinião do crítico, Astolfo Marques deturpa e rebaixa a sociedade maranhense ao insinuar que o "populacho" e suas festanças sintetizam os significados cultuais máximos da identidade regional. Em outras palavras, os incômodos do colunista se dirigem à concepção de identidade maranhense forjada nesta obra, na verdade, à enunciação da cultura do ponto de vista da população negra e pobre. Com efeito, quatro anos mais tarde, Antonio Lobo sintetizaria o balanço geral da recepção da obra considerando que:

(...) certa maledicência indígena julgou descobrir desdoiros a reputação da terra, porque nele apenas se desenhavam cenas e movimentavam tipos de categoria social inferior, como se essa não fosse também uma das faces do viver maranhense, capazes de estudo por processos beletrísticos. A despeito, porém, dessas reles e despeitadas intriguinhas de bastidores, o livro caminhou, magnificamente acolhido pela crítica extra-estadual, porque encerrava, deveras, predicados de valor, entre os quais sobrelevava a observação flagrante e impecável, colhendo diretamente da vida os assuntos que lhe serviam de entrecho (LOBO, [1909] 2008, p. 118).

Embora Antonio Lobo desvalorize o que anota como "reles e despeitadas intriguinhas de bastidores" estas constituíam parte significativa na construção da pessoa pública de um autor num meio literário tão concêntrico. Embora a crítica ao trabalho intelectual de Astolfo Marques, que veio aos jornais, seja favorável a sua obra, é provável que sua reputação de péssimo escritor, assinalada postumamente, seja conseqüência direta de um recurso poderoso de controle grupal: a fofoca.

No caso de A Vida Maranhense não conseguimos localizar a mencionada crítica extra-estadual da obra o que nos informaria a partir de representações simbólicas como o autor foi recebido. Entretanto, o próprio Antonio Lobo dá notícia de um texto no qual Medeiros e Albuquerque, crítico nacionalmente respeitado, dedica-se a obra de Astolfo Marques e o fixa como um escritor "essencialmente descritivo".

Quanto às obras Natal e o Dr. Luiz Domingues, a presente investigação logrou êxito em localizar parte da recepção do autor em outros estados brasileiros. Os dois textos publicados no jornal Diário do Maranhão, nos dias 25 de 27 de fevereiro de 1909, com os títulos Livros Novos - Natal, Astolfo Marques (1908) e Notas - Natal, Astolfo Marques (1908), vinham de jornais piauienses, respectivamente $O$ Monitor e O Comércio, ambos sediados na capital Teresina. Esses dados que corroboram a hipótese da existência de um sistema literário interligado nestes estados. Nesse sentido, vale destacar a republicação de um pequeno comentário ao livro o Dr. Luiz Domingues, publicado no mesmo jornal, dia $1^{\circ}$ de 
abril, sob o título Bibliografia, vindo do jornal O Amazonas de Manaus. Nesta nota, além dos elogios, informa-se que Astolfo Marques é o correspondente maranhense do referido jornal nortista e, que na Rua Henrique Martins, na Agência Freitas, o livro encontra-se à venda para o público amazonense.

A única crítica francamente negativa e ácida que conseguimos localizar veio nas poucas linhas dedicadas ao romance A Nova Aurora (1913), na coluna Prosa e Verso do jornal A Pacotilha. No intuito de fazer um balanço das mais recentes publicações do ano, afirma o autor do texto:

Astolfo marques, desde que se instituiu a Oficina, nunca mais se apartou do aparo, ora perdendo
tempo nas gazetas, ora imprimindo seus livrinhos. A Nova Aurora apresenta-nos um quadro dos
costumes localistas, retratando muitos tipos que ainda hoje nos acotovelam, aqui e ali,
imutavelmente lorpas e cheios de boas intenções. A "broca da análise" extrairá dessas laudas
várias descaídas, sem reparar que o dessabor das cenas contribuiu em grande parte, para tais
defeitos. Era impossível comunicar vivez a paisagens monótonas, desenxabidas. Isto só os gênios
conseguem. Ora o Astolfo não aspira a tanto. E depois representa um verdadeiro arrojo o editar
qualquer coisa, hoje em dia, no Maranhão.
O mercado está vasqueiro. O Raul gastou as pestanas, mas corroborou sua fama de cronista com a
interessante novela. Dos males, o menor.

A cordialidade e simpatia que deu tom das críticas às obras anteriores do autor desaparecem nestas linhas. O crítico, que dá mostra de conhecer a trajetória do autor desde o tempo da Oficina dos Novos, considera sua produção intelectual uma grande perda de tempo. A ironia que conduz a mordacidade da crítica vai desde o uso provocativo do diminutivo em "livrinhos" até a afirmação de que a única vantagem da obra consiste no arrojo que representa publicar qualquer coisa no Maranhão. No entanto, para além das "laudas descaídas" de que tem sido capaz a pena do escritor o crítico identifica no objeto que perfaz a matéria do livro, "tipos que ainda hoje nos acotovelam, aqui e ali, imutavelmente lorpas e cheios de boas intenções", o principal problema de A Nova Aurora. É no desgosto imanente ao cotidiano do povo maranhense que pairam os principais defeitos do romance. Para o crítico, só um gênio para transmitir alguma vivacidade aquelas plagas e Astolfo Marques certamente não era o caso.

É provável que A Nova Aurora, último livro publicado pelo autor, seja responsável por parte do descrédito que enovela sua obra ficcional. Embora não tenhamos encontrado no mesmo período outros textos que corroborem as posições do articulista de Prosa e Verso, é provável que as "intriguinhas de bastidores", parafraseando Antonio Lobo, tenham feito a desgraça da obra. Em 1951, nem mesmo a simpatia que Domingos Vieira Filho acalentava pelo escritor o impediu de asseverar que em Astolfo Marques se o contista é 
equilibrado "o romancista, entretanto, surge falho de originalidade. O seu único romance é vulgar. As melhores páginas do livro lembram o estilo de Eça, mas é um estilo em caricatura".

Talvez seja justamente devido a esse duradouro consenso negativo acerca do seu único romance a que o autor teve o desprazer de assistir na ocasião de sua publicação que o motivou a dar conhecimento a única crítica literária de foro internacional, localizada nesta investigação, a respeito do seu trabalho. Com efeito, em julho de 1915, quando Astolfo Marques trabalhava como redator-chefe do cotidiano $O$ Jornal, fez publicar uma longa crônica do escritor português Orlando Marçal a respeito de A Nova Aurora. Segue o texto na íntegra:

\author{
Norte de Portugal \\ (Crônica)
}

A Nova Aurora

Astolfo Marques, o requintado artista literário que tão belas páginas oferta aos seus ledores, orgulhou-me, há tempos, com a magnífica prenda da sua auspiciosa novela A Nova Aurora. Sob as minhas olaias rumorosas, aos brandos afagos dum sol primaveril, tendo por manto o azul ilimitado do firmamento na placidez da paisagem ofuscadora que se largava para o longe, na severa tranqüilidade da natureza em redor, que bulício algum alterava, embalei o espírito na contemplação desse produto admirável que a sua cordialidade carinhosa fez chegar aos meus olhos. Eu lhe agradeço profundamente comovido aos momentos deleitosos que a sua leitura me proporcionou. Li a esplêndida novela grande e original na sua simplicidade de fazer arte, duma extraordinária pureza descritiva, sem arrebiques e esforços, sem os embaciamentos a tons estranhos que se notam em as que anceiam ultrapassar os limites do possível.

Os espíritos contemplativos como o meu, inclinam-se sempre as provas plenas de ingenuidade e meiguice, misto de sentimento e fantasia, a que são propensos os verdadeiros artistas da prosa, e Astolfo Marques tem o condão essencial de, inspirando-se em temas que agradam a severa psicologia do público ledor, ao saber pintar e emoldurar em perfeitas formas que certamente o hão de impor a admiração sincera dos que o acompanham através na jornada literária.

Li o precioso volume, desde logo o recomendei com aquela pressa do orgulho que se sente, quando se anuncia uma boa nova. Na brilhantíssima revista paulista A Vida Moderna, por certo um dos magazines que no vasto e estremecido país se publicam, honrando-o sobremaneira entre os nacionais e estranhos, o semanário que o público brazílico tanto acarinha e distingue e onde fulgem, a orientá-lo duas das maiores organizações artísticas que enobrecem essa privilegiada raça descendente da portuguesa, - o poeta ilustre que é o Dr. Julio Cesar da Silva e sua irmã, a eminente intelectual dona Francisca Julia da Silva, - nessa afamada e lindíssima revista, apressei-me eu a escrever, na minha secção Sol de Portugal, alguns períodos desataviados e descoloridos, de homenagem humílima, mas cordial, que rememoro e novamente subscrevo, com o mesmo calor e afeto:

"Do Brasil, esse país galhardo e encantador, onde a natureza vibra maravilhosamente em manifestações bizarras e que fulge em minh'alma em transportes de veneramento e adoração, hei recebido, em diversas épocas produções intelectuais, remessas amáveis e penhorantes de escritores de inconfundível talento e as quais tenho dedicado muito do meu entusiasmo de moço e a transparência de recolhida e justificada admiração.

Assim, desde as manifestações artísiticas, opulentas e de beleza e de poder inspirativo do saudoso poeta Arthur Goulart, cujo o apartamento da vida sentidamente pranteei, até as felizes e superiores conceções de Paulo Barreto, Alamachio Diniz, Francisco Gaspar, Gustavo Teixeira, Carlos Maúl, Aristeo Seixas e tantas outras produtivas mentalidades que formam a brilhante geração literária que orgulha esse progressivo país, eu, d’ora em vez, sou agradavelmente surpreendido com a 
oferenda gentil de preciosos altares erguidos a beleza e a verdade, ante os quais o meu espírito se delicia e extasia.

Entra hoje no meu gabinete de trabalho, como fulgente rajada de carinhoso sol, neste dia enevoado e tristonho, um volume valioso do laureado prosador maranhense Astolfo Marques, de título sugestivo, A Nova Aurora.

É um interessante episódio regional, onde palpita, intenso e comovido, um largo e regeneroso coração de artista que sabe pintar, em cores sadias e puras, as atitudes agitadas dum meio buliçoso e inquieto, descrevendo com singular relevo literário tipos e situações dificílimas.

Porque não é o só o descritivo exato do tablado onde faz girar heroes criados que o animam e lhe espargem muito luz o que no belo livro se aprecia; é sobretudo o relevado vigor do entrecho, em largos tons de gesto de gesto pitural, o savoir faire dos transes surpreendentes, que eleva nas suas páginas, no propósito de emocionar os ledores, cativando pela maneira delicada de fazer arte, numa prosa doce e suave, como o deslizar brando de um arroio, por onde perpassa, cintilante e vivo, um veio dourado de sonho admirável.

Astolfo Marques, produziu um romance que se lê sem enfado, com o maior prazer espiritual, revelando tamanhas qualidades de analista, que seria imperdoável não as revigorar em sucessivos trabalhos para o alcance da consagração a que se talento tem direito.

Ao nobilíssimo confrade, a cuja obra reservo um lugar nas páginas do meu livro de crítica literária, uma vez mais agradeço vivamente penhorado a oferta gentil do seu elegante volume, anceando-lhe as maiores venturas e o mais ruidoso triunfo.

Vila Nova de Fozcoa, - julho de 1915.

Orlando de Marçal

Tudo leva a crer que a publicação da crônica fora encomendada pelo próprio autor. Minha hipótese é que no intuito de salvar a reputação de seu romance, Astolfo Marques, assim que soube da publicação existente no periódico literário A Vida Moderna, fez questão de divulgá-la no Maranhão. Não sei se quando o escritor enviou o romance ao crítico português já tinha acertado por carta que o mesmo escrevesse, para além da crítica a ser publicada na revista paulista, uma crônica especialmente dedicada ao público maranhense, ou se o autor enviou nova carta pedindo o prelúdio para valorizar mais ainda o texto. De qualquer forma, o caráter de encomenda prevalece.

É interessante que o crítico português demonstra não apenas já conhecer Astolfo Marques como afirma já ter dedicado em alguma de suas obras de crítica literária atenção ao trabalho do escritor. Infelizmente não temos dados que esclareçam a natureza dessa relação, mas fica a hipótese de que Fran Paxeco, então cônsul de Portugal, possa ter estabelecido o contato entre ambos.

Os elogios de Orlando Marçal vão de encontro a todas críticas sofridas pelo autor à data ou mesmo postumamente. O articulista de $O$ Sol de Portugal considera a novela "grande e original", sua máxima virtude é a pureza descritiva, a ausência da tentativa de ultrapassar os limites estéticos oferecidos pela realidade. Desta maneira, A Nova Aurora teria 
a vantagem de se adequar a "severa psicologia do público leitor". O comentário não poderia soar mais irônico para um ambiente literário que aparentemente repudiou a obra.

Com efeito, se para alguns o livro continha imagens monótonas e desenxabidas, o crítico português considerava que o prosador soube pintar em "cores sadias e puras" um meio social agitado e inquieto "descrevendo com singular relevo literário tipos e situação dificílima". Neste sentido, não só a matéria analisada é relevante, mas o estilo do autor consegue lhe transmitir um brilho singular.

Orlando Marçal é o único crítico literário até o presente a conseguir ultrapassar o efeito de realidade estilisticamente construído por Astolfo Marques na consideração de que "não é só o descritivo exato do tablado onde faz girar heróis criados que o animam e lhe espargem muita luz o que no belo livro se aprecia" destacando os "largos tons de gesto de gesto pitural, o savoir faire dos transes surpreendentes". A relevância do comentário não reside no caráter simpático da crítica, o qual, inclusive, é deveras exagerado, mas na tentativa de desnudar o que há de criação artística e invenção da realidade no trabalho do escritor.

O realismo quase fotográfico com que Astolfo Marques descreveu a realidade social do Maranhão nas primeiras décadas do regime republicano tem chamado a atenção dos historiadores contemporâneos para a sua obra. Mais uma vez, é o caráter "essencialmente descritivo" do autor que está em relevo, sua proclamada fidelidade aos fatos. É como se a acusada falta de imaginação autoral pudesse agora lhe redimir através da ciência histórica.

Neste sentido, o desafio que o corpus crítico contemporâneo ou póstumo põe à investigação sociológica da obra ficcional de Astolfo Marques é descobrir na eficaz ilusão artística de objetividade com que o autor ora seduziu, ora tornou-se medíocre ao seleto público de literatura no Maranhão da Primeira República, o modo como a realidade é deformada, isto é, expressão singular de uma visão de mundo. Se o trunfo de Marques mesmo que malfadado no julgo da posteridade - foi a "sinceridade boa de suas descrições", a cópia "fiel" do dia a dia, será preciso desarmá-lo para entender como escritor cotejava seu mundo e, quiçá, qual idéia fazia da arte literária. 


\section{Duas tradições: a configuração de um projeto intelectual}

No artigo O Natal de 1908, publicado em 5 de janeiro de 1910 no Diário do Maranhão, Astolfo Marques expressou todo o seu descontentamento com o estado das festas natalinas da cidade. "Parece que o povo se vai aos poucos desapegando da tradição." Ao contrário de outros tempos em que inúmeros presépios tomavam a cidade e por várias ruas encontravam-se belas apresentações pastoris, o dezembro de 1908 o decepcionou muito:

\footnotetext{
Poucos são agora os velhinhos que, reunindo filhos e netos, presidem, como em outros tempos, com o seus alvinitentes cabelos, esse acontecimento máximo do universo que é o Natal.

Também os bailes, muito comuns pelas festas natais, estão dizendo um "adeus irônico" ao passado.

Já não se dança nesta terra que tinha foros, aliás justíssimos, de filha de Terpsichore.

A classe musical está aniquilada. Os poucos muzicianos vivem numa luta constante, dezunidos, emaranhados em interminável dissensão (Diário do Maranhão, 5 de Janeiro de 1910).
}

O autor critica com veemência o "desapego da tradição". A beleza do Natal, "esse acontecimento máximo do universo", também partilha da cena comovente em que filhos, pais e avós reúnem-se em torno da mesa e, assim, perpetuam os costumes do povo maranhense. A prova da decadência dos valores regionais foi a pouquíssima quantidade de bailes que ocorreram no fim do ano anterior. A classe musical está destruída e as pessoas já não dançam numa terra famosa pela qualidade de suas festas.

As críticas de Astolfo em $O$ Natal de 1908 podem nos ajudar a compreender uma das intencionalidades do seu trabalho ficcional. Neste caso, a preservação da cultura popular maranhense. Vale notar que ao fim do mesmo ano em que diagnostica o derruimento da tradição ele lançou o seu Natal, livro inteiramente dedicado às festas natalinas tradicionais.

É possível afirmar que a configuração do projeto intelectual do autor é cindido entre o esforço de elaborar a história intelectual das elites dirigentes locais, como é o caso da Seleta Maranhense, e guardar a memória das tradições populares da região, seja através da pesquisa histórica, como em Festas Populares Maranhenses, seja por meio dos vários contos que publicou em revistas, livros e jornais.

Quando confrontamos os resultados da pesquisa acerca do autor nos periódicos com a investigação realizada através dos jornais, é possível objetivar uma idéia mais concreta desse processo. Na seção Os Periódicos Literários, notamos que as revistas revelavam algumas estratégias do próprio autor para viabilizar sua carreira literária: 1) o controle prático de todas as atividades da Oficina dos Novos, o principal grupo literário maranhense da primeira década do século XX;2) o investimento intelectual denso sobre a história intelectual das elites; 3) o desenvolvimento de um estilo literário afinado com o regionalismo. Outro 
dado observado foi que o período de 1900-1903 foi o de maior indefinição na carreira de Astolfo Marques, um momento no qual ele estava definindo o seu próprio perfil intelectual.

A pesquisa nos jornais A Pacotilha, Diário do Maranhão e O Jornal confirma o resultado que objetivemos com as revistas literárias. No período de 1900-1903 foi localizada uma parte desconhecida da atividade intelectual de Astolfo Marques: o trabalho de tradutor. No jornal A Pacotilha, ano de 1900, encontramos quatro traduções de Astolfo Marques: 1) A Princesa da Harpa de Ouro, por seções nos dias 23, 24, 25, 26, 27, 28 e 30 Julho; 2) $O$ Casamento da Hermância, por seções nos dias 20, 21, 22, 23, 24, 27, 28 e 29 de Agosto; 3) A Princesa Muda, por seções nos dias 19, 20, 21, 21, 24, 25 e 26 de Setembro; 4) Conto de Natal, no dia 24 de Dezembro. No ano de 1901, o mesmo jornal publicou outras duas traduções do autor: 1) O Ano Bom, em $1^{\circ}$ de janeiro; 2) $O$ Três Reis, nos dias 4, 5, 7 e 8 de Janeiro. Em 1902, A Pacotilha, apenas uma tradução: 1) O Palácio de Neve. Em 1903 foi a última tradução localizada nesta investigação de título Anos Mortos ao longo de todo o período de $1900-1918^{20}$.

Escusado dizer que o Boletim Comemorativo não catalogou esses dados, os quais corroboram o argumento de que entre 1900-1903, Raul ainda não sabia bem que destino traçar para si na vida intelectual. Não sabia nem mesmo como registrar seu nome nestes trabalhos uma vez que o autor assinou a primeira das traduções listadas como "Raul Marques", isto é, sem o "Astolfo" com o qual registrou toda sua obra posterior. Nessa fase de indecisão, dividia o trabalho de contista e biógrafo, que só publicava nos periódicos literários, com o de tradução de textos, os únicos que conseguia publicar nos jornais.

Destaca-se que, nesses quatro anos, apareceu apenas um trabalho ficcional do autor nos jornais selecionados para a pesquisa, A Procissão do Redentor, publicado no dia 13 de novembro de 1903 em A Pacotilha, só no fim do ano. Antes dele, o mesmo jornal publicou a crônica $O$ Socialismo Entre Nós, no dia $1^{\circ}$ de maio. Havia, no momento, pouco espaço para a visibilidade dos trabalhos ficcionais do autor nos jornais. ${ }^{21}$

\footnotetext{
${ }^{20}$ Ver a bibliografia completa das traduções no final desta dissertação.

${ }^{21} \mathrm{Na}$ época, era hábito dos jornalistas e literatos publicarem seus textos nos jornais assinados por pseudônimos. Neste sentido, embora diferentes dados corroborem o argumento de que o trabalho de tradutor demarca a inserção de Raul Astolfo Marques na imprensa, e de que havia alguma restrição aos seus primeiros escritos ficcionais, não descartamos a possibilidade de que o autor possa ter se valido de pseudônimos. Em História da Imprensa no Maranhão, o pesquisador Antonio Lopes (1889-1950) afirma que Astolfo Marques também colaborou no jornal $O$ Federalista (1959, p.112). Entretanto nossa investigação no referido diário não identificou artigos do autor. Caso o historiador, um contemporâneo de Raul, esteja certo é provável que a colaboração tenha ocorrido através de pseudônimos.
} 
Em O Diário do Maranhão, no período de 1900-1904, apenas um trabalho de Astolfo Marques foi localizado. Trata-se de um conjunto de estudos intitulado Odorico Mendes: apuntos biográficos, publicado nos dias 10, 12, 14, 19, 23 e 27 de Dezembro de 1901, o mesmo tipo de trabalho a menos de dois meses daquela data foi iniciado na Revista do Norte. Em resumo: o trabalho como tradutor foi fundamental para que Astolfo Marques conseguisse se inserir na imprensa local. Não posso deixar de notar a coincidência de que 1903 é também o ano de sua vitória no $2^{\circ}$ Concurso Francisco Guimarães, isso leva a inferir que a conquista possa ter aberto algumas portas antes fechadas.

Logo no ano seguinte, 1904, aparecem bem mais produções do autor no jornal $A$ Pacotilha. No $1^{\circ}$ de janeiro, publicou o conto A Opinião da Euzébia. Dia 6 de Fevereiro vinha à luz A Discussão da Firminas. Ambos os contos foram reunidos na seção A Peste do livro A Vida Maranhense. O conto O Socialista, apareceu a 8 de Março de 1904. A crônica, $O$ Fundador, também desconhecida até esta pesquisa, veio a lume dia 9 de Abril de 1904. Nenhum dos textos estava relacionado no Boletim Comemorativo. Outro conto que também foi incluído em A Vida Maranhense, Os Dois Herdeiros, fora publicado no dia 3 de maio. No fim do mesmo ano, apareceram os contos $O$ Vinho do Núncio e o Presépio do Nicolau, publicados, respectivamente, nos dias 26 de novembro e 24 de dezembro. O primeiro conto também fora publicado no Boletim da Oficina dos Novos, em novembro de 1904, e o segundo incluído no livro Natal (1908).

Em 1905, Astolfo Marques publicou bem menos em A Pacotilha. Fato que não parece estranho, pois como vimos anteriormente o autor estava organizando a publicação de seu livro de estréia e, a acreditar nos seus críticos, ter publicado A Vida Maranhense foi um sufoco. Ainda sim, no dia 22 de Abril apareceu o conto Vestido de Judas, posteriormente publicado na Revista do Norte (Março, 1907). Um texto interessante sobre uma das principais manifestações populares carnavalescas do Maranhão. Dia 13 de Maio, o autor publicou o conto de título Ser Treze, inédito até então, sobre os significados da abolição para os escravos libertados pela Lei Áurea.

Em 1906, o autor publica no Diário do Maranhão suas "notas e impressões de viagem" De S. Luiz a Therezina, nos dias 4, 9, 10, 11, 12, 13, 14, 15, 16, 17, 18, 20, 21, 22, 23, 25, 27, 29, 30 e 31 de Agosto e completa com mais artigos nos dias 1, 3, 5, 6 e 7 de Setembro. Afora esse longo estudo, dia 27 de Agosto, Flavio Reimar Junior, pseudônimo de Astolfo Marques, fez um necrológio sobre o Cônego Damasceno Ferreira. Neste mesmo ano, em A Pacotilha, apareceram três trabalhos: Os Socialistas Alemães e o Congresso de Manheim, crônica publicada dia 10 de novembro, e Novos Horizontes, crônica publicada 13 
dezembro, os dois assinados com o pseudônimo de Flavio Reimar Junior. E finalmente, $O$ Natal de Rufino, conto publicado dia 25 de novembro de 1906;

Note-se que dois contos, O Presépio do Nicolau (1904) e O Natal do Rufino (1906), foram incorporados ao livro Natal (1908). A contracapa de A Vida Maranhense (1905) indicava que o segundo volume de contos dedicados à temática seria composto por contos escritos entre 1904 e 1905. É provável que ambos os textos estivessem incluídos originalmente no segundo volume do livro de estréia do autor. Entretanto, Astolfo Marques teve algumas razões para mudar de idéia. Acredito que a decadência das festas natalinas na cidade o tenha motivado a escrever um "livro de intervenção", com vistas à valorização dessa manifestação popular.

Também é possível que o autor tenha adiantado a publicação de certos contos por motivações comerciais. No dia $1^{\circ}$ de dezembro de 1908, encontramos a pequena nota: "Natal de Astolfo Marques (Da Academia Maranhense de Letras), plaquette contendo cinco quadros maranhenses, 1 vol. 2,000. A venda em A Revista do Norte e nesta redação”. Neste sentido, penso que o escritor encontrou naquele dezembro a oportunidade para ganhar algum dinheiro. Isso pode ter mexido com o projeto inicial do segundo volume de A Vida Maranhense. Quando observamos a contracapa de Nova Aurora (1913), encontramos sob a indicação "A Entrar no Prelo" a seguinte notação: "Fitas... (Esboços e quadros) $2^{\mathrm{a}}$ e $3^{\mathrm{a}}$ série do vol. publicado com o título A Vida Maranhense, 2 vols." Tudo indica que Natal tenha provocado mudanças no formato nos planos do autor.

Merece destaque adicional o pseudônimo de Astolfo Marques, identificado pela primeira vez nestas investigações. Esse é um dado muito importante para a compreensão do projeto intelectual do autor. Mas vamos por partes. Ao analisar a coluna Pedras à Opinião, no jornal A Imprensa, ano de 1907, encontramos um artigo polêmico escrito pelo escritor José do Nascimento Moraes ${ }^{22}$, sob o pseudônimo de Brás Cubas, contra um tal de Flavio Reimar Junior. Trata-se de um pseudônimo que remete à memória de Gentil de Almeida Braga (18351876), o qual assinava suas crônicas como Flávio Reimar23. Ou seja, o cronista atacado por

\footnotetext{
${ }^{22} \mathrm{O}$ escritor negro maranhense José do Nascimento Moraes (1882-1958) foi professor, jornalista, poeta, crítico literário e romancista. Seus principais trabalhos publicados são o conjunto de ensaios de crítica literária e social intitulada Puxos e Repuxos (1910), o romance Vencidos e Degenerados (1915) e o ensaio político Neurose do Medo (1923). Deixou inédito o livro de poesias Círculos sem que seja possível precisar a data de composição, além de uma gama de contos não publicados. Foi fundador da revista literária Athenas e como jornalista trabalhou para diversos jornais como A Campanha, O Maranhão, A Pátria, Diário de São Luis, O Jornal, A Tribuna, A Hora, Diário do Norte, Diário Oficial, O Globo, Correio da Tarde, A imprensa, Notícias, dentre outros.

${ }^{23}$ Gentil Homem de Almeida Braga foi um dos principais escritores da geração romântica maranhense. Contribuiu com os principais jornais de sua época como A Coalição, Ordem e Progresso, O Liberal, Publicador Maranhense além de participar periódico literário Semanário Maranhense, o mais importante órgão do
} 
Moraes considerava-se filho espiritual de Braga e, por isso, leva a seguinte alfinetada:

Flavio Reimar, si espiritualmente vives, desce da Posteridade, por um momento, para falar a teu filho, e si te não for possível descer, envia-lhe num raio luminoso um pensamento sublime que o faça acordar do letargo em que vive, para não mais se assinar Flavio Reimar Junior, e sim, de ora avante, única e simplesmente - Astolfo Marques (A Imprensa, 27/04/1907).

De acordo com Nascimento Moraes, Flavio Reimar Junior era o pseudônimo de Astolfo Marques. Destaca-se que o texto criticado fora publicado na seção Crônica Maranhense do jornal Folha do Norte no Pará. Não pude consultar o Diário do Maranhão de 1907, jornal atacado ao longo de todo artigo, para ver se havia alguma resposta do próprio Astolfo Marques ou da redação do cotidiano contra as injúrias. A existência de alguma réplica poderia nos esclarecer, sem nenhuma de chance de erros, se de fato Astolfo assinava sob o pseudônimo de Flavio Reimar Junior e talvez nos daria a chance raríssima de vê-lo arrolado numa polêmica literária.

Nada disso pôde ser verificado. Entretanto, é muito provável que Nascimento Moraes houvesse realmente retirado a máscara do autor pesquisado. Passamos a verificar se existiam matérias assinadas por Flavio Reimar Junior nos jornais de São Luís. Em $A$ Pacotilha de 1907 encontramos os seguintes títulos: O Ensino Profissional Agrícola; A Conferência de Haya; Pattapio Silva; O Trabalho e a Paz; A Questão de Tutoia I; A Questão de Tutoia II. Como se vê pelos títulos, trata-se de um conjunto de crônicas sobre assuntos diversos, mas com ênfase em problemas locais, como a questão dos limites do Maranhão e do Piauí debatidos nos artigos dedicados à A Questão de Tutoia. Ao cruzar esses textos com os que já possuíamos do autor, nota-se semelhanças de estilo e a preocupação com temas semelhantes, fato que nos encoraja manter a hipótese de que Flavio Reimar Junior é mesmo pseudônimo de Astolfo Marques.

Este dado é mais revelador quando sabemos que o autor pretendia lançar um livro formado exclusivamente de crônicas. No jornal A Pacotilha, ano de 1910, duas matérias são particularmente relevantes para o caso. A primeira delas é a crônica A Escola Profissional, publicada no dia 5 de janeiro, em que Astolfo Marques apóia os esforços governamentais em prol da reabertura da Escola de Educandos Artífices, fechada desde o advento da República (1889). Neste artigo, também não relacionado na bibliografia de Astolfo Marques, encontramos a seguinte indicação após a assinatura do autor: "Do Quatro anos de crônica, no prelo". Isso indica que o mesmo desejava lançar um livro com suas crônicas escritas nos

romantismo local. Notabilizou-se na crônica com o pseudônimo de Flavio Reimar, nas quais desenvolveu sua escrita agradável e a crítica bem humorada e ferina aos costumes locais. 
últimos quatro anos (1907-1910). No jornal Diário do Maranhão foram localizadas duas crônicas com a mesma indicação: O Natal de 1908 - publicado no dia 5 de janeiro de 1910 e O Sermão do Encontro - publicado no dia 24 de março de 1910.

As três crônicas mencionadas acima possuem a indicação de "no prelo", fato que indica que o material já estava pronto. É estranho que na contracapa de A Nova Aurora não tenhamos encontrado nenhuma referência ao livro Quatro Anos de Crônica. O autor pode ter desistido de publicá-lo ou não considerá-lo um projeto tão relevante quanto a Seleta Maranhense ou o livro sobre As Festas Populares Maranhenses. De qualquer maneira, se Nascimento Moraes tem razão ao afirmar que Flávio Reimar Junior é Astolfo Marques, considero possível que as crônicas assinadas sob o pseudônimo seja parte integrante do livro Quatro Anos de Crônicas. Nesse caso, a descoberta de "Flávio Reimar Junior" pode ter nos oferecido um livro perdido do autor estudado. Este fato, só poderá ser plenamente assegurado com a investigação da coluna Crônica Maranhense do jornal paraense Folha do Norte.

Quando comparamos o número de textos publicados por Astolfo Marques no jornal A Pacotilha, em relação ao Diário do Maranhão, no período (1907-1910), o primeiro jornal sai na frente. Em 1907, o autor publicou naquele diário dois contos. São eles: Aqueles Aduladores e As Trezenas do Cazuza, publicados, respectivamente. nos dias 13 de maio e 13 de junho. O primeiro texto relata, ficcionalmente, como eram organizadas as tradicionais Festas de Santo de Antonio nos meios populares maranhenses. O segundo é uma crítica ao sentido da abolição. Narra as frustrações de um ex-escravo que não tinha convite para ir ao baile que comemorava a Lei Áurea. Em 1908 foram encontrados os seguintes contos do autor: 1) De Corôa e Barrete, sobre o carnaval dia 2 de Março; 2) A Cartola do Geraldo dia 20 de julho; 3) Em Paz, dia 4 de dezembro como divulgação do livro Natal (1908); 4) Presentes de Festas, publicado dia 25 de dezembro.

No mesmo período considerado, O Diário do Maranhão, publicou apenas as crônicas anteriormente mencionadas. Devemos fazer a ressalva de que o ano de 1907 não foi localizado. Mesmo assim, se olharmos para o período anterior (1900-19005), veremos que foi A Pacotilha que abriu as portas da visibilidade pública para o autor. Entretanto, em 1910, aparece um texto fundamental para a interpretação de sua trajetória intelectual: As Festa de São Benedito publicado dias 2, 4 e 5 de abril de 1910.

Trata-se da maior descoberta arquivística para estas investigações. O autor desenvolve uma análise histórica e etnográfica sobre a festa de São Benedito no Maranhão, na qual, logo abaixo ao título encontramos a indicação "Capítulo dum livro em preparação - As Festas Populares Maranhenses". Esse livro, segundo Fran Paxeco, no necrológio de Astolfo 
Marques, publicado no jornal A Pacotilha dia 28 de junho de 1918, encontrava-se perdido. Até o momento, o referido trabalho é o único documento que nos permite remontar o desenho original de um dos trabalhos com que Astolfo Marques mais se debateu. Podemos remontar sua origem ao projeto de análise etnográfica da cultura do Maranhão e exposta nos artigos sobre o cancioneiro e, o romanceiro regionais e os tipos populares publicados nos anos de 1900, 1901 e 1902 no Boletim da Oficina dos Novos. Na contracapa de A Vida Maranhense (1905) encontra-se a indicação “As Festas Populares Maranhenses (Em preparação)”. Da mesma forma, a indicação se repete em 1913 na contracapa do livro A Nova Aurora. Fica a dúvida se capítulos do livro não foram publicados em jornais e revistas literárias de outros Estados do Norte.

Com o desenvolvimento da pesquisa no jornal A Pacotilha, nos anos de 19111918, localizaram-se apenas dois trabalhos do autor: 1) As Nossas Habitações, artigo publicado dia 20 de janeiro de 1912; 2) As Exportações Maranhenses, janeiro de 1917. Salvo algum deslize na coleta de dados acreditamos que os fatores que explicam a exigüidade de artigos de Astolfo Marques no cotidiano em que ele mais publicou na primeira década do século possuem outras razões. Os anos de 1911 e 1912, por exemplo, marcam a entrada do escritor como secretário interino do Liceu Maranhense. Estes também são os anos que antecedem a publicação do romance A Nova Aurora, cujo trabalho de escrita, como sugere a indicação da última página da obra, findara em novembro de 1912. Também vale a pena lembrar que de 1911 até abril de 1912 o autor compôs a redação do Diário Oficial em que publicou os seguintes trabalhos: 1) A Conservação do Porto, artigo publicado dia no 25 de outubro de 1911; 2) As Nossas Habitações, no 3 de janeiro de 1912; 3) A Comemoração de Reis, dia 8 de janeiro de 1912; 4) A Defesa Agrícola, nos dias 3 e 14 de fevereiro; 5) Quaresmais, nos dias 8, 14 e 20 de março de $1912^{24}$. Ou seja, é possível que as tarefas do autor no funcionalismo público o tivessem afastado um pouco de A Pacotilha.

Por outro lado, em 1915, um novo cotidiano aparece no cenário maranhense: $O$ Jornal. Astolfo Marques é descrito, sem precisão exata do período, como um dos primeiros redatores chefes deste jornal na nota de falecimento do autor divulgada pela folha ${ }^{25}$. Dada esta informação, analisamos o citado jornal de 1915-1918. No primeiro ano de existência do jornal, o autor publicou os seguintes trabalhos: 1) Artistas Guerreiros, artigo, sobre artistas

\footnotetext{
${ }^{24}$ Todos esses artigos são citados na bibliografia do autor elaborada na ocasião do seu centenário.

${ }^{25}$ De acordo com o necrológio do escritor, publicado no próprio diário: “A morte do Astolfo Marques causa fundo abalo no meio intelectual, onde era bastante estimado e leva a orfandade duas inocentes crianças que eram o enlevo de seu lar. O Jornal, que durante largo tempo esteve sob a criteriosa direção do ilustre homem de letras, registra compungido o lutuoso acontecimento, enviando-lhe o eterno adeus, numa braçada de flores que depõe sobre a sua sepultura" (O Jornal, 27 de Maio de 1918).
} 
alistados na primeira guerra mundial no dia 7 de Janeiro; 2) Casamentos Gorados, conto, em 19 de janeiro; 3) Entrudo e Penitência, conto, no dia 15 de fevereiro; 4) O Carnaval nas Ruas, crônica, em 17 de fevereiro; 5) Quaresmais: a procissão da cana-verde, estudo histórico, no dia 19 de Março; 6) Quaresmais: a procissão dos navegantes, estudo histórico, em 26 de Março; 7) A Deserção do Noitante, conto, no dia 22 de junho; 8) As Fogueiras do Consolação, conto, no dia $1^{\circ}$ de Julho; 9) O Brasil Social, resenha do livro A Organização Nacional de Alberto Torres, saiu no dia 16 de Julho. Ainda em 1915, publica-se, dia 5 de outubro, a seguinte nota: "Seguiu para S. José do Ribamar, ontem, em busca de melhoras, o nosso prezado colega Astolfo Marques". Acreditamos que pode se tratar dos primeiros indícios da tuberculose que em menos de três anos faria o escritor cair em óbito.

Em 1916, o autor consagra em O Jornal uma coluna de título Comentários dedicada às crônicas sobre a vida social maranhense e resenha de livros considerados importantes por Astolfo Marques. Comentários veio a lume dias 14, 23, 30 e 31 de agosto, 11, 14, 20 de setembro, 13, 14, 15 e 25 de outubro e 20 de dezembro. Vale a pena frisar que nenhum desses doze pequenos textos haviam sido incluídos em quaisquer bibliografias conhecidas do autor. Neste mesmo ano, os únicos textos de Astolfo Marques publicados fora dos Comentários são Os Crimes do Hipnotismo do dia de 3 de Março, a republicação de As Fogueiras do Consolação do dia 29 de junho e Reis Republicanos do dia 24 de dezembro.

A passagem dos anos de 1916 e 1917 pode ter sido muito difícil para Astolfo Marques. Neste último ano, o escritor só publicou dois textos em O Jornal. São eles: 1) Presentes de Festa, conto, no dia 2 de janeiro; 2) Comentários, crônica, no 24 de janeiro. $\mathrm{Na}$ verdade, Presente de Festas consistia na republicação de um texto que, como vimos, saíra em 1908, quase dez anos atrás.

Formulamos aqui três hipóteses para a refração da produção literária do autor em seus últimos anos de vida: a) o desenvolvimento da tuberculose; b) a nomeação para o cargo de chefia da $2^{\text {a }}$ Seção da Secretaria do Interior em abril de 1917; c) a dedicação em finalizar trabalhos como As Festas Populares Maranhenses ou em publicar a sua Seleta Maranhenses, textos que infelizmente nunca vieram a lume. 
PARTE II 


\section{As Cores da Aurora}

\section{História e Contra-História da República}

Um aspecto chama a atenção do leitor logo nas primeiras folhas de A Nova Aurora. A obra contém duas dedicatórias surpreendentes. Numa página temos: “'̀ memória dos republicanos históricos no movimento adezipnista do Maranhão à proclamação da República: Paula Duarte, Sousândrade, Isaac Martins e Sátiro Farias”. Na página seguinte lê-se: "Homenagem a memória dos populares que tombaram mortos em nome da causa monárquica”. Duas alusões que a priori se excluem mutuamente. De um lado os republicanos históricos maranhenses, do outro, os ex-escravos que morreram num violento protesto contra o 15 de novembro. O escritor Josué Montello, certa vez, arriscou uma explicação:

\footnotetext{
As duas homenagens não se contradizem, ao contrário do que, à primeira vista, se há de presumir. Astolfo Marques, contemporâneo da Proclamação da República, ajudara a consolidar o novo regime. Daí a homenagem aos próceres do movimento republicano, em sua terra natal. Mas, por outro lado, testemunhara uma cena única em sua terra natal: vira os negros libertos a 13 de maio descerem as ladeiras da cidade, armado de pedras e pedaços de pau, para empastelarem o jornal que anunciava a Proclamação da república. E alguns morreram, repelidos pelas balas da força policial, nesse impulso heróico de reconhecimento e gratidão.

Daí a homenagem de Astolfo Marques (MONTELLO, 1993, p. 122).
}

Se não há contradição, existe contudo a ambivalência. Numa página, tributa-se o romance à singularidade de quatro homens ex-senhores de escravos, políticos e intelectuais que por cerca de uma década se deblateraram por uma das palavras de ordem da modernidade: a República. Na outra, uma gente negra que morrera lutando contra as incertezas do pósabolição, por não saber até que ponto o alardeado progresso não lhe custaria a perda da liberdade. De um lado, a camada intelectual que Marques tanto admirava e lutou para se ver nela como um dos seus. Do outro, o povo humilde do qual o autor era originário, sujeito e personagem principal do seu trabalho ficcional. No centro, um pensamento cindido entre a realidade crua do autoritarismo republicano nos seus primeiros dias - a memória dos negros assassinados pelo exército, trabalhadores presos e torturados, o silêncio noturno dos toques de recolher, a impunidade orientada pela política - e a utopia de que a aurora de um novo mundo sem senhores nem escravos, a sociedade do verdadeiro homem livre e cidadão havia raiado imerso às tristezas daquelas manhãs de novembro.

Essas dedicatórias suscitam um problema particularmente complexo. Não apenas por entrelaçarem a irredutibilidade da experiência autoral à autonomia da obra como objeto estético, mas por sugerir de modo tácito e específico os desafios da mediação simbólica para 
os intelectuais negros. Aquilo que o sociólogo afro-americano W. E. B. Dubois chamou de dupla consciência para assinalar a dificuldade de traduzir as expectativas modernas de igualdade, liberdade e reconhecimento da dignidade humana, a luz da memória viva da escravidão e a experiência da subordinação racial.

É significativo que o ponto alto do romance histórico de Astolfo Marques seja a narração minuciosa do fuzilamento de ex-escravos monarquistas em 17 de novembro de 1889 . O conflito foi o desenlace trágico da tensão entre os republicanos que anunciavam através do jornal $O$ Globo a queda da monarquia e os negros que para lá acorreram com o fito de empastelar a folha pelo temor da re-escravização. Um choque que materializa o desafio de conjugar subjetivamente identidades inacabadas, como ser negro, republicano e intelectual na aurora do Estado-nação brasileiro. Um confronto, que lança a sensação indizível do "medo da escravidão" como um ponto narrativo de partida para escrever e refletir sobre os sentidos da modernidade no Brasil. Um texto que encerra um jogo ambivalente de identidades sociais e pessoais conflituosas, interpelando-se pela diferença e conformando-se imersas no mesmo: na mesma contingência histórica, no mesmo destino social.

A chave para compreender isto não reside na separação precipitada das formas culturais
particulares a ambos os grupos em alguma tipologia étnica, mas uma apreensão detalhada do seu
complexo entrelaçamento. As realizações intelectuais e culturais das populações do Atlântico
negro existem em parte dentro e nem sempre contra a narrativa grandiosa do iluminismo e seus
princípios operacionais. Seus caules cresceram fortes, apoiados por um entrelaçamento da política
e das letras ocidentais (GILROY, 2001, p. 114-5).

A própria estrutura do romance A Nova Aurora reflete o que sociólogo britânico chamou de "complexo entrelaçamento". A primeira parte do livro é dedicada à situação da classe dos ex-senhores após o 13 de maio. O esclarecido militar Marçal é o personagem principal. Herdeiro de uma fortuna amealhada com trabalho escravo nas fazendas de arroz do seu pai, suas atitudes e reflexões expressam as incertezas das elites agrárias nos meses que sucederam a abolição. A segunda seção apresenta os movimentos populares que reagiram ao autoritarismo republicano, a perplexidade de homens do povo que idealizaram o novo regime como uma vitória da democracia e a presença do preconceito racial ameaçando a construção de uma sociedade igualitária. Por último, o autor nos sugere caminhos de integração social com base na reforma do Estado e nos valores cristãos de fraternidade universal.

Essa complexidade de interesses e expectativas sociais entrelaçadas no tempo e no texto sugere que escrever A Nova Aurora foi a experiência arrojada de uma "autobiografia coletiva" e impessoal. Uma tentativa de fazer com que a própria realidade histórica, retratada exclusivamente pela exterioridade bruta com que os fatos oprimem as escolhas humanas, 
pudesse também dramatizar, conscientemente ou não, as ambivalências pessoais de ser negro e intelectual tal qual o movimento puro do tempo, envolvendo o leitor como se cada palavra pudesse ser trocada por fragmentos da própria realidade. Trata-se de uma grande farsa, ou melhor, uma ficção, um romance histórico com um final feliz, contendo secretamente a tensão da própria identidade. 


\title{
ASTOLFO MARQUES
}
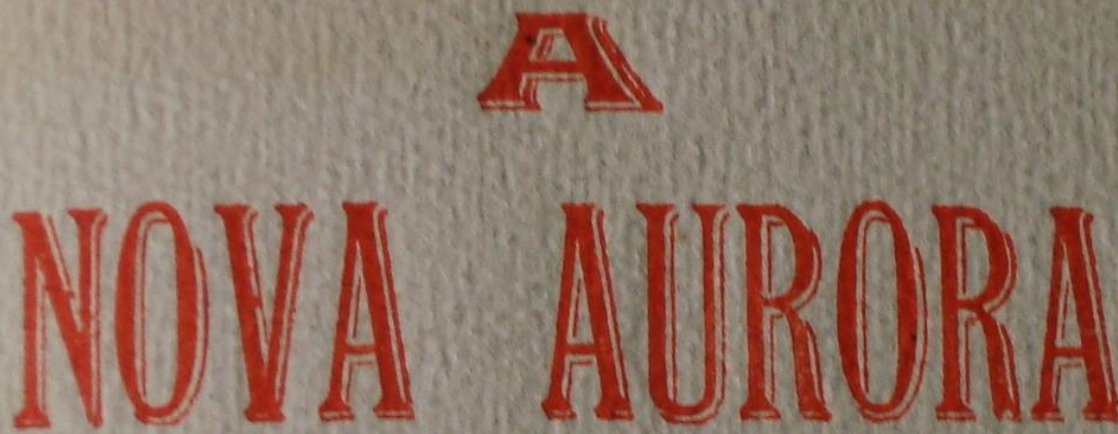

\section{(NOVELA MARANHENSE)}

$$
\text { \#纱 }
$$

\author{
TIPOGRAVURA TEIXEIRA
} MARANHAOO-1913 


\section{A Regeneração Social}

Antes mesmo de adentrar a narrativa do romance é provável que o leitor contemporâneo demorasse alguns segundos tentando entender o título do primeiro capítulo: $A$ Regeneração Social. Um começo demasiado estranho para nossa sensibilidade intelectual mas deveras comum no discurso político, científico e literário da primeira república. Ele expressa a tentativa de compreender o mundo social como um corpo biológico capaz de se regenerar ou degenerar sobre determinadas condições ambientais, esforço que caracteriza parte significativa do pensamento sociológico durante todo o século XIX. Mas no caso de A Nova Aurora diz um pouco mais ao anunciar que o foco central do livro é a própria realidade social do Maranhão.

Isto não significa que o autor nos conte uma estória que simbolize a essência da sociedade ou faça uso de metáforas que revelem os mecanismos políticos e sociais que singularizam aquela região. Nesse livro, a sociedade não é o pano de fundo no qual se desenrola a história de um indivíduo ou grupo social mas o personagem central da trama. Em outras palavras: o Maranhão em fins de 1889 não é contexto nem pretexto mas o próprio texto. Fato que constitui uma das principais características do foco artístico dos literatos maranhenses nas primeiras décadas do século passado, ou seja, problematizar a reconstrução da identidade maranhense a luz das recentes transformações no mundo trabalho, bem como nas relações políticas.

\footnotetext{
A produção intelectual da elite letrada maranhense na República Velha teve como marca sonante a disposição para a reflexão sistemática sobre o Maranhão. Ao tempo em que visava elucidar as especificidades históricas do torrão natal, essa atitude tinha por norte identificar e alicerçar imagens basilares e fundantes do Maranhão que fossem passíveis de utilização simbólica no processo de construção identitária, de sentido novo, reclamada naquela época prenhe de transformações. Para esses letrados, o Maranhão deveria ser repensado desde de suas entranhas mais profundas; nesse sentido, a eles competia realizar o mapeamento dos entraves paralisantes da vida ativa regional e indicar alguma projeção de futuro que engendrasse uma realidade estadual renovada, revigorada pelo influxo de tempos fáusticos, tomados como referências imorredouras (MARTINS, 2006, p. 115).
}

A Nova Aurora está no epicentro dessas preocupações que ocupam os agentes do campo intelectual maranhense. O romance radicaliza o projeto de elucidação histórica e cultural das bases sociais da identidade regional. Nossa leitura habituada à separação rija entre ciências humanas e literatura mal tolera a sensação de indecisão entre ambas na escritura da obra, extensível ao descrédito contemporâneo das propostas mais exageradas do Naturalismo. A idéia de regeneração social que dá nome a toda problemática do primeiro capítulo dialoga 
com a necessidade de cumprir com as exigências da moderna sociedade brasileira, generalização do trabalho livre assalariado, crescimento econômico e democratização da esfera pública. A escravidão fez do Maranhão um corpo doente que precisa expurgar seus cancros e adquirir novo metabolismo social, é preciso sangue novo para animar as veias de uma terra esterilizada por sua própria violência. Mas quais os pilares sociais concretos que a história daquela sociedade podia contar para renovar sua marcha? A república? O povo? A modernização da agricultura? A eugenia social? Eis a dúvida que diversificou as imagens de um futuro redentor.

Em Astolfo Marques, os desafios da regeneração social e por conseguinte da própria trama são os limites que o próprio meio social e político impõe a concretização de um Estado republicano democrático. Os títulos dos demais capítulos reafirmam estes aspectos: Cap. II Na Alvorada da República; Cap. III A Proclamação da Democracia; Cap. IV As Festas Adezonistas e Cap. V O Natal da Liberdade. Esses nomes parecem indicar que a noção da arte literária enquanto instrumento intelectual capaz de levar a compreensão dos fenômenos políticos e sociais, sem nada dever as ainda incipientes ciências humanas, teve em A Nova Aurora um de seus exemplos. De maneira direta e objetiva, o escritor negro dirige a atenção do leitor para os processos sociais e eventos coletivos, impressiona que nenhum desses títulos se refira à vida particular ou características psicológicas de uma personagem do romance e com exceção do último figurariam de bom grado num livro de história política do Brasil.

Mesmo a alegoria da aurora, poética e forte, usada nos momentos significativos da obra, refere-se ao clima de pavor e instabilidade política instalado no Maranhão, quando a primeira junta governativa republicana assumiu o poder entre 18 de novembro de 1889 e 17 dezembro do mesmo ano. A matéria do romance é precisamente esses 29 dias marcados por prisões arbitrárias seguidos de decretos de deportação e fuzilamento, perseguição e tortura de populares, assalto aos cofres públicos e corrupção administrativa. Pode-se dizer que a alegoria da aurora simboliza criticamente o estado indefinido e duvidoso dos significados da República, ali partida entre luzes da esperança democrática e sombras da tirania oligárquica. Com efeito, o governo provisório é considerado um dos períodos mais sombrios da vida política maranhense. Em sua História do Maranhão, Barbosa de Godóis (1860-1923) descreve em tintas indignadas a ação da Junta Republicana:

Trêfega e irriquieta, longe de consagrar os animos, para que todos cooperassem no regimen que se inaugurava, procedeo com exclusões, n'uma terra em que não passavam uma meia dusia os republicanos historicos e procurou aproveitar-se da eventualidade que lhe pusera o governo nas mãos, para atirar-se á faina de formar elementos politicos que servissem aos planos de dominio de um só dos seos membros, que tinha pretenção a chefe do partido. 
Accorde com esse pensamento, a policia commettida na propria capital a pessôas as menos idoneas para exercerem-na, por conhecida falta de critério, tratou ahi mesmo de se impor pelo medo, effectuando prisões a torto e a direito, castigando co palmatoadas as pessôas do povo d'um e outro sexo e raspando-lhe a navalha as sobrancelhas e metade do cabelo na cabeça.

Ninguem se reputava seguro n'uma tal emergência, em que a liberdade individual estava em perigo permanente.

Não houve escala de violencia que a junta, não tocasse, chegando até a tentar deportações e fusilamentos e isto sem que houvesse o menor indicio que fosse de resistencia a nascente forma de governo (GODÓIS, 2008 [1904], p. 361).

A análise historiográfica do terceiro vice-governador do Maranhão republicano demonstra que, mesmo entre as classes dominantes, o governo provisório foi vivenciado como período de grande instabilidade política. O recurso abusivo da violência policial, prisões e torturas criaram um clima de pavor e ameaça à liberdade individual. $\mathrm{O}$ medo fora o principal auxílio da ordem. Decretos de fuzilamento e deportação foram expedidos com o fito de intimidar a ação populista dos monarquistas. Nem mesmo as mulheres escapavam das agressões justificadas como medidas necessárias à preservação do novo regime. Entretanto, para o historiador, mesmo não havendo um clima pró-republicano na véspera, as arbitrariedades eram fruto exclusivo da "faina de formar políticos que servissem aos planos de domínio de um só de seus membros, que tinha a pretensão de chefe do partido".

No romance, Astolfo Marques oferece uma descrição minuciosa sobre o modo como as camadas populares viveram a chegada dos "tempos modernos" naqueles dias de violência e pânico. Aliás, é no confronto entre as expectativas de progresso alardeadas na campanha republicana e a ditadura violenta instalada pela junta, que a alegoria da aurora desvela seu sentido crítico ${ }^{26}$.

A provável inspiração do autor quanto a utilização alegoria da aurora vem da obra republicana do poeta Joaquim de Souza Andrade (1832-1902), mais conhecido como

\footnotetext{
${ }^{26}$ Ainda não se tem notícia de algum documento no qual o escritor explique os motivos que o levaram a nomear seu único romance de A Nova Aurora, fato que dificulta sobremaneira esta análise. Por outro lado, sabemos que o termo aurora foi largamente utilizado como título de jornais e periódicos desde o pós-independência até o início do século passado. A copiosa Exposição Commemorativa do Primeiro Centenario da Imprensa Periodica no Brazil de 1908, registra hebdomadários como Aurora Pernambucana (Pernambuco, 1821), Aurora Fluminense (Rio de Janeiro, 1827), Aurora (Pernambuco, 1849) Aurora Paraense (Pará, 1853), Aurora Cearense (Ceará, 1866), A Aurora (Pernambuco, 1867) A Aurora (Piauí, 1894), Aurora (Amazonas, 1908) dentre outros. Nestes casos aurora parece ser uma alusão ao caráter matutino da distribuição dos jornais e a rotineira chegada do novo - novas informações, idéias e perspectivas - através da imprensa. Vale a pena lembrar que ainda em 1877, futuros republicanos históricos como Silva Jardim, Quintino Bocaiuva e o famoso poeta maranhense Raimundo Correia, quando alunos do Colégio D. Pedro II no Rio de Janeiro editaram um jornal de idéias republicanas e abolicionistas cujo nome era precisamente A Nova Aurora. O memorialista Dunshee de Abranches relata a rivalidade existente no meio estudantil do Liceu maranhense entre o folheto abolicionista Aurora Literária e sua respectiva charge Aurora Boreal, neste caso o termo aurora simboliza a tentativa de renovação dos cânones literários e as expectativas políticas de mudanças no regime de trabalho insufladas pela abolição antecipada no Ceará (1884). Isso tudo sem esquecer a sugestiva afinidade sonora entre a palavra aurora e áuria, nome da lei que aboliu definitivamente a escravidão legalizada. Neste sentido, a alegoria da aurora inseria o autor num código intelectual usual e conhecido.
} 
Souzândrade, que além de ser citado diversas vezes no romance, também integra a dedicatória do livro. Em seu extenso poema republicano O Novo Éden (1893) bem como em jornais consagrados a esta causa como O Globo e o Novo Brazil, ambos citados por Astolfo Marques, a metáfora da aurora é recorrente. Ao disputar o mérito da abolição com os monarquistas, explica o poeta:

Ora, quem fez o 13 de maio foi a aproximação da República, a aurora que surge espancando as trevas; e o espírito do civismo e de equidade, que inspirava, teria associado os libertos às famílias e nunca desorganizaria as vivas indústrias da Pátria, se escrevesse a lei. (SOUZÂNDRADE, 2003 [1889], p. 498)

A alegoria da aurora assinala o compromisso com uma concepção linear e evolutiva do tempo subsumida na noção de progresso $^{27}$. As "trevas" da tradição escravista são espancadas pela luz do civismo e da igualdade. Aurora é, portanto, a certeza apoteótica dos "novos tempos", as alegrias da modernidade demarcadas pela emancipação dos cativos e a promessa de democracia. A República não é apenas um sistema de governo, mas um futuro inevitável da trajetória do esclarecimento humano - "Sócrates a traçou, Platão elevou-a ao ideal, o Cristo a cumpriu” (2003 [1889]: 499) - uma intuição renovada do mundo capaz de reconciliar pela fraternidade e a lei, interesses políticos tão diversos quanto os que separaram no ato de 13 de maio os ex-senhores e ex-escravos.

Foi nesta certeza que Astolfo Marques pretendeu inserir a dúvida. Tão logo finda a leitura das primeiras páginas do romance descobrimos que Aurora é o nome da chácara na qual as transformações sociais e políticas de novembro de 1889 são observadas e concretamente vivenciadas pelas personagens. Esta quinta de "ubérrimas terras dominadas pela espaçosa e invejável casa de vivenda" congrega todas as características da província. Ela é a terra em si mesma. Em cada canto do lugar encontra-se um pedaço simbólico do Maranhão. Aurora é ao mesmo tempo um lugar e uma visão da realidade. Ouçamos o narrador:

\footnotetext{
${ }^{27}$ Num trecho representativo de $O$ Novo Éden, temos a associação entre modernidade, tecnologia, progresso, liberdade e república conectadas pela alegoria da aurora: "Os ceus do astro polar! Canta, canta o futuro, Oh Silenciosa Musa! E rindo em áureo cantar: Formas, século-vinte, além do dezenovel Dos telephonios sons em que Edson nos ouve! Dos relâmpagos-luz, bella eletrecidade, \Pestenejar de Jove, em fixa claridade! IDo animal-magnetismo e o Deus-vivo occultismo!\ Do telescopio, olhar p'ra os céus com Flammarion\E os admirar com Kant qual à moral, e vezes \Choral-os mortalmente - ai Vesper de Phaon!\ Do esbrazeiamento Eiffel, torrehymnos marselhezes! Do sino de São Paulo, orgulho dos Inglezes\Liberty-Bell rachado ao (incêndio) d'Abion!! Qual Brazil ao Cruzeiro, adíssechens serpentes $\backslash$ Contra Libertas, Deus! e o eterno Tiradentes $\backslash$ Que a noite secular desperta cóo meteoro, $\backslash$ Do exercito senhor, que envia em bem, Deodorol O grande braço unido a sublimada fronte $\backslash$ De Benjamim, (o ideal d’América ao horizonte), $\backslash$ De paz guerreiro maior que o marcio Napoleon, $\backslash$ Que onde ha revoluções a flores, liberdade (...) (SOUZÂNDRADE, 2003 [1893], p. 210).
} 
Era num dos extremos da cidade, em bairros dos mais pintorescos, e por entre as ruínas dos ranchos da outrora florescente Fazenda do Medeiros, que se erguia, no seu estilo sinjelo, a confortante caza de vivenda da grande chácara que o Marçal Pereira encontrara chamando-se Aurora, ao adquiri-la para sua morada.

Achava-se ellla situada em local donde a vista abrangia fartamente o antigo e amplo dominio do senhor da Quinta do Marajá, com a sua fonte cristalina agua entregue a serventia publica. Em pozição, na perspectiva, a pequena ermida da Santa festividade tradicional, com suas duas torres muito alvas, ao lado do cazario pompozo, extremado pelo bellissimo palacête do Pororoca, rezidencia do solitario antiste, ainda abatido do acerbo sofrer que lhe movêra o orgam dos interesses da sociedade moderna; á frente, a estatua de marmore branco do mais vultuozo lírico pátrio. Mais além, os negrejados paredões da "Casa do Navio" e de outras edificações inconclusas, atestando, nas suas ruínas esboroadas, o trabalho frutificante e o zelo empreendedor de Medeiros, nas duas primeiras décadas do século XIX; ao nascente, a Gambôa do Mato, a cuja sitio se ia de constante, á cata de salubridade reconfortadora, beneficamente facultada pelas suas altitude e viração ventina; mais ao lado da floresta, onde, de pouco palmilhar o pé humano, parecia silvestre, e se comunicava pela parte sul, com o Mamoím, abrigando sua secular fonte, condenada por imperdoável desleixo, a escoamento completo; pelo lado norte, bem a fronteira, a "Victoria", a formoza chacara do solitario poeta do Allah errante, ostentando alto e extenso planejamento de gradís de ferro por sobre os muros pintados a vermelhão, paralelos ao vasto Tabocal, e guardando ciozamente a variegada coleção de arvoredos frutíferos, em copados e verdejantes especimens; ainda proximo, o edifício da cadeia, de arquitetura banal, em um imenso quadrilátero de altas paredes, cobertas de espêsso limo por amontoados invernos (MARQUES, 1913, p. 11-12).

Não há saída para os olhos. A vista da Aurora é uma cidade em desterro. Para onde quer que se vire encontramos a beleza e o espírito empreendedor que moveu o passado completamente cercado pelas ruínas do presente. Todos os símbolos estão atirados às traças, "a fonte secular condenada por imperdoável desleixo". A história une, na mesma paisagem, a "estatua de mármore branco do mais vultuoso lírico pátrio" - o poeta maranhense Gonçalves Dias - junto aos "negrejados paredões da Casa do Navio", que atestam a falência dos sonhos de progresso e desenvolvimento quando São Luís fora a quarta maior província do Império Brasileiro nas duas primeiras décadas do século XIX. A poesia romântica, que emerge da “formoza chácara do poeta solitário" Souzândrade, se confunde com o limo amontoado dos invernos que cobre logradouros abandonados. O tempo é uma mistura insustentável de glória e decadência. Os maranhenses esperam em sua própria terra o sabiá que Gonçalves Dias cantou no exílio e anseiam contra o dia o dia da derrelicão uma nova aurora, pois as manhãs do presente são iguais:

Era o mesmo sempre o brilho, fosse a luz pura da manhã nascente, ou ao sol crescente, no zenit, ou ainda pelo crepúsculo vespertino, quando, às bandadas, garças, na sua alvura do gesso, e guarás, todos tingidos de rubro, pipiando alacres e ariscos, num esbater meticuloso e rápido de d'azas descrevendo curvas, ora alongadas ora curtas, contornavam os ares, - mais acima, parecendo perto das nuvens, mais abaixo, tocando a flor d'água, - tornavam da faina cotidiana ao seu poizo, aos ninhos nas siribeiras entigueadas e no mangal florido e reverdecente (MARQUES, 1913, p. 13).

A imagem é rica. Em pleno devir, o acontecimento histórico está aprisionado pela

natureza. $\mathrm{O}$ brilho da aurora é o mesmo do crepúsculo. $\mathrm{O}$ mundo envelhece sem qualquer 
transformação no curso das coisas, a faina cotidiana segue a rotina e previsibilidade da vida não-humana. $\mathrm{O}$ vôo alto do guará se contrapõe à visão estreita e baixa dos homens da terra.

Neste sentido, Aurora engloba como visão da realidade a ruína do espaço e a melancolia do presente e oferece, em contraste, as excelências de uma terra sempre fértil, capaz de se renovar a cada momento de esterilidade. Seus portões abrem o Maranhão paradisíaco dos cronistas que o amaram. A descrição da natureza exuberante da chácara tenta nos mostrar que mesmo cercada pela visão do abandono político existe uma terra pronta para realizar todas as alegrias de um povo.

Em seus caminhos desvelam-se as "forças naturais" da identidade local através da "frescura verdejante e cheirosa a hortaliça, que medrava em canteiros e mais canteiros simetricamente dispostos", "altas e esguias juçareiras pojadas de cachos, por entre laqueadas palmeiras de buriti, no ciciar agudo e cantante de suas ramagens". A própria natureza canta o seu pertencimento à terra. A diferença é descrita como excepcionalidade. $\mathrm{O}$ cultivo da tradição se desvela desde os regionais pés de abricó e sapoti com "que sussurrava, com vivacidade, um arvoredo frondozo" até sua costumeira roda de conversação noturna e domingueira em que "se passavam a revista homens e coisas locais, em vivissemos comentários. Joga-se o sólo, bebericava-se café e, uma vez ou outra, ceiava-se peixe frito como farinha dá-agua", prato que até hoje não pode faltar numa boa reunião maranhense.

A descrição da chácara é demorada e algo enfadonha. O leitor é arrastado entre os maracujazeiros que separam a casa de vivenda e o portão principal, o solo ladrilhado deste percurso e "as seculares jaqueiras com o pomo brotando desde o tronco". O narrador valoriza o espaço enriquecendo quantitativamente a descrição de detalhes. É como se para entender o livro tivéssemos que primeiro nos apoderar, lentamente, do valor simbólico da Aurora. Neste romance:

(...) a descrição assume importância fundamental, não a modo de enquadramento ou complemento, mas de instituição da narrativa. É ela, de fato, que estabelece como denominador comum a supressão das marcas de hierarquia entre o ato, o sentimento e as coisas, que povoam o ambiente e representam a realidade perceptível do mundo (CANDIDO, 2004, p. 65).

A descrição tem que nos levar de fato a ouvir os citados cantos e sussurros da terra, pois tudo o que habita Aurora só tem existência relevante como parte de sua melodia nativa. A ausência narrativa de vida psicológica interior de Marçal Pedreira, personagem central da trama, estabelece de modo grosseiro a supressão da diferenças entre o ambiente e a individualidade, neste caso, entre Aurora e o seu proprietário. É como um componente da aurora que ele será descrito. Só os seus atributos rigidamente sociais da personagem 
interessam a estrutura do livro e depois de tê-los descrito ainda no primeiro capítulo a personagem será em certa medida abandonada no desenrolar da estória, ou melhor, será reduzida a condição de ouvinte, posição análoga a do leitor.

De Marçal, o narrador quer que entendamos apenas que é tão filho da terra como a palmeira de buriti, "descendente, em linha direta, de antigos e abastados lavradores da região do majestoso Itapecurú", cujas águas cortam a província de norte a sul. Nas margens do Itapecuru, a personagem nasce ligada a todo o Maranhão. A morte dos pais o acomete ainda na menoridade, ficando a cargo de um tutor até receber uma aquinhoada herança que lhe garante a independência política e pessoal. Tanto que se casou com uma "matrona" "sem eira nem beira e que pelos janeiros carregados nos costados, poderia servi-lhe de mãe”, opção matrimonial nada convencional. Sem nenhuma palavra sobre a vida íntima do casal, ou as alegrias do nascimento de sua única filha Cornélia, descobrimos no mesmo parágrafo em que se casou que após um ano ficara viúvo.

Mais uma vez destaca-se a pouquíssima ênfase na vida particular e individual da personagem. Nem mesmo o casamento é um pretexto interessante para o narrador discorrer sobre os sentimentos de Marçal. Um dos raros momentos em que descobrimos um traço de sua personalidade, a independência intelectual, a narrativa descreve suas convicções políticas. Contente com sua farda de capitão da Guarda Nacional, Marçal não quis fazer carreira política e se militava no partido liberal como todos os Pedreiras "não ia a ponto de negar as grandes conquistas amplamente liberais que para o paiz lograra fazer o partido adverso - o conservador." Motivo de sua grande admiração por conservadores abolicionistas como Eusébio de Queiroz e o Visconde do Rio Branco.

A personagem só é anotada no enlace entre pessoa, meio e história. A rigor, Marçal Pedreira é uma instituição social: é o proprietário da chácara, pai de Cornélia, eleitor do partido liberal, capitão da Guarda nacional. O narrador iguala a descrição da personagem à caracterização de seu status social. Ele tenta nos dar sem qualquer mediação, o jogo de espelhos entre Marçal e os demais freqüentadores da roda em Aurora e delatar com sutileza uma sociedade hierárquica em que a individualidade é suprimida pela insígnia do lugar social. Relata o narrador:

No baile de estrondo, da elite social, em honra da oficialidade da esquadra Wandenkolk, tivera o Marçal o exultante prazer de fazer arrastar a sua espada virgem de batalhas pelos vastos salões do palacete Corrêa Leal, e ombreara ufano com o príncipe d. Pedro Augusto de Saxe. Também o Marçal exibira o luzido uniforme nos salões do munificiente baile com que os bancos e as Associações Comercial e Agrícola se demonstraram para o todo o sempre gratas ao presidente Beltrão (...). 
O capitão Pedreira bem que se exteriorizara na época de tanto deslumbramento, á cata de outras relações porventura ainda não cultivadas, a busca de ver o nome nas colunas dos quotidianos da província. E assim se mantinha relacionado sempre, até mesmo com as famílias dos mais intransigentes adversários políticos (MARQUES, 1913, p. 21-22).

Manter-se relacionado sempre, até mesmo com intransigentes adversários se possível, zelar pelo prestígio do nome nas colunas sociais, exibir as marcas rituais da distinção social, o uniforme luzido e a espada são os códigos rituais que regem o mundo de Aurora, a sociedade maranhense apresentada por Astolfo Marques. Ali se vive do que é possível ostentar. Não estranha que todas as personagens do romance funcionem como o "cavaleiro inexistente" de Ítalo Calvino, realizadores perfeitos de seu status social, feitos apenas da armadura e o brasão com que os demais podem reconhecer sua posição hierárquica, mas sem nada por dentro da espessa ferragem - a diferença é que o narrador de A Nova Aurora descreve a armadura e o brasão com se fossem a própria carne e o osso.

A pequena descrição de Cornélia à mesa do pai, "toda loira e graciosa, pompeante nos seus dez anos, toda finura das suas feições, linda com seus lindos olhos, bela com seus cabelos belos", leva as últimas conseqüências este movimento narrativo. No belo sexo a armadura pega carne. $\mathrm{O}$ autor adentra a extensa lista de intelectuais negros que reservam para a mulher branca o lugar da beleza imaculada, arrolando a menina como um patrimônio de seu pai. Por ser mulher, seu corpo efetivamente faz parte do seu status social, daí o destaque para a juventude, beleza e brancura de Cornélia. Os outros dotes óbvios da pequena são a castidade, educação e a religiosidade, sugeridos pelo vestido colegial de cambraia branca e um cordão de ouro com crucifixo, "artístico e fino produto da ourivezaria portugueza" contrapontos rituais do uniforme militar e a espada do orgulhoso papai.

Em Aurora, portanto, todos os seres estão quase ritualmente localizados. A descrição das demais personagens segue a monotonia desta regra. O leitor conhece num só parágrafo o Landerico Atunes, Romualdo Nogueira, Camillo Souza e o Augusto Souza, assíduos freqüentadores da quinta. $\mathrm{Na}$ verdade, somos apresentados as seguintes posições sociais, respectivamente: oficial mecânico da Usina Rapozo e adulador do capitão Marçal Pedreira; amanuense aposentado dos Correios e escriturário da Fábrica Gamboa; os dois últimos são mecânicos da citada fábrica. Só mereceu um pouco mais de atenção o Jovino Carvalho "acadêmico de direito, estacionado na terceira série do curso, havia seis anos, depois de passar cinco no Recife, a dissipar sem dó as mesadas, sem nenhum progresso nos estudos”, preferindo "na sua ociosidade latente, o cavaco e o sólo da quinta do Marçal a uma 
reconciliação com a família que lhe dera por seca a teta". Temos, portanto, o estudante, o malandro e o boêmio aí condensados.

É essa pequena galeria de tipos sociais que Aurora faz circular debaixo do carramanchel todas as noites quando o sino da Cadeia bate nove horas. O enredo do livro são as histórias e fuxicos da vida política ali relatados na véspera e primeiro mês de proclamação republicana. Não se relata qualquer fato da vida privada. Ora é o próprio narrador que toma a palavra e esclarece os temas do debate público, ora é este mesmo quem informa que a estória contada páginas atrás fora dita por alguma personagem. Esta estratégia permitiu que capítulos e sessões do romance ganhassem a forma de conto, gênero literário com que o autor estava bem mais habituado ${ }^{28}$.

A onipotência do narrador e a quase inexistência de diálogos diretos entre as personagens - que não aparecem nos momentos centrais da trama - confere a estas um papel reativo. É o meio que age sobre elas e toma as principais páginas do romance. ${ }^{29}$ Ou melhor, o imperativo da narração sobre as personagens formaliza literariamente a concepção de que a sociedade determina a ação e a moral dos indivíduos. E no romance, os imperativos da regeneração social sobre aqueles homens eram atravessados pela disjunção entre as expectativas democráticas abertas pela abolição e a propalada estagnação da lavoura. Se por um lado foram "os festejos em multiplicidade perene, salientando-se, no seu esplendor maximo e brilhantismo desusado, as procissões da saídas da Sé, de N. S. da Vitória, promovida pelos libertos de 13 de maio", por outro, "não havia roda ou conciliábulo de comerciantes ou lavradores onde se não mostrasse quão apreensiva era situação econômica presente comparada com a do passado, para o qual se entoavam hinos e teciam loas" (p. 22). A ironia é fina e central, uma vez que:

\begin{abstract}
Nas memórias, romances e relatos feitos pelos antigos senhores de escravos, a abolição aparece como ruptura decisiva dos padrões, etiquetas e valores estabelecidos na ordem escravista. Havia um interesse político e ideológico dos senhores em conceber a abolição nesses termos. A idéia de ruptura servia como importante argumento para mostrar o quanto a classe senhorial havia sido abandonada e injustiçada pela decisão do governo imperial de abolir a escravidão. E mais que isso, o fato de que a abolição não fora precedida nem pela indenização, nem por leis complementares que garantissem algum controle sobre os libertos (FRAGA FILHO, 2006, p. 139).
\end{abstract}

\footnotetext{
${ }^{28}$ Esse arranjo na estrutura do livro permitiu que Astolfo Marques reeditasse integralmente o conto $O$ Discurso do Fabrício, publicado originalmente em A Vida Maranhense (1905), no capítulo IV de A Nova Aurora.

${ }^{29}$ Vale destacar que no capítulo mais importante da obra, Na Alvorada da República, nenhuma personagem se faz presente. $\mathrm{O}$ narrador domina e analisa os fatos de ponta a ponta, deixando a cargo do leitor a pressuposição de que as personagens da obra, assim como ele, tomaram ciência dos fatos.
} 
Em A Esfinge do Grajaú, memórias do jornalista e político maranhense Dunshee Abranches, descendente de uma abastada família de fazendeiros, o capítulo A Crise da Abolição informa que "a extinção brusca do regime negreiro, com o êxodo das fazendas e das casas dos senhores nas cidades e vilas, causou um tremendo colapso na vida utilitária da Província (32)." Este abolicionista convicto fora sensível aos sentimentos de sua classe registrando paradas cardíacas, acessos de loucura e que até mesmo "uma velha senhora de engenho, tronco de ilustres políticos conservadores, tentou suicidar-se, ingerindo ervas venenosas". Ao longo da república velha, o tema do "golpe da abolição", tornou-se menção obrigatória nas análises econômicas e históricas e peça chave no antigo discurso sobre a decadência da lavoura maranhense. ${ }^{30}$

A idéia de "extinção brusca" do trabalho escravo também comparece, agora em tintas conservadoras, no desfecho da História do Comércio do Maranhão de Jerônimo de Viveiros. No capítulo derradeiro, A Catástrofe Agrícola e a Loucura Industrial, o autor afirma que o 13 de maio deixara o ex-senhor "atordoado pelo golpe que lhe arrancava parte do patrimônio, estarrecido diante da desorganização do seu trabalho, agora sem braços, com êxodo dos ex-escravos, que das fazendas partiam para a festa da redenção da raça (...)”. A abolição é, portanto, um desmerecido golpe daqueles que julgavam justa a "punição do escravocrata que havia no lavrador. Esqueciam-se porém que eles tinham deveres para com aquele trabalho, cuja evolução custara dois séculos e ingentes e perseverantes dos nossos antepassados". Em suma: a emancipação dos cativos foi analisada e vivenciada por parte significativa da elite letrada como um ataque a tradição e história maranhense.

Não sem razão, todo o esforço crítico do escritor em sua narrativa é reforçar uma explicação de longa duração para estagnação econômica. Para o autor, o comércio provinciano "que em tempos remotos atingira notável grau de prosperidade, destacando-se das demais circunscrições imperiais, vinha de certa época para cá definhando, caindo em preocupadora estagnação, oriunda de múltiplas cauzas” (p. 22). A provável fonte de Astolfo Marques é a Transformação do Trabalho: memória apresentada á Associação Comercial (1888) de Dunshee de Abranches. A pretensão política da obra, apresentada aos queixosos escravistas da Associação Comercial do Maranhão ainda no calor do 13 de maio, era precisamente deslocar da Abolição as responsabilidades sobre a crise econômica. Nessas memórias, as queixas comuns da elite ex-senhorial como escassez de braços e o fracasso da

\footnotetext{
${ }^{30}$ Para uma análise mais detida sobre o discurso da "decadência da lavoura" ver: ALMEIDA, Alfredo Wagner. Ideologia da Decadência. Amazonas: Casa8, 2008.
} 
colonização são plenamente contempladas, porém, inteligentemente relativizadas durante a narração.

No mesmo sentido, Astolfo Marques procura destacar fatores como perda da exclusiva intermediação econômica entre as províncias vizinhas (Ceará, Piauí e Pará) e a metrópole portuguesa. A falta de visão dos fazendeiros e não buscar alternativas para o alto custo da produção algodão, considerando perene a boa situação no comércio internacional advinda da guerra civil americana. Finda esta, "esse mesmo comércio provinciano, como meio único de remediar os males originados do erro em que havia caído, teve retrair-se em suas operações". O problema da escassez de braços é analisado tendo como ponto de partida a guerra do Paraguai que "retirara dela [a lavoura] para o exército avultado número de braços válidos, ao mesmo tempo que a exportação de escravizados, de há muito praticada em grande escala, privava os estabelecimentos agrícolas desse elemento vital". Ou seja, o "golpe" é fruto de antigos erros e ganâncias da própria classe senhorial.

A crítica ao discurso da vadiagem e preguiça dos trabalhadores rurais é notável em sua análise dos insucessos da colonização agrícola. $\mathrm{O}$ autor assinala as péssimas condições da mão de obra retirante, observando que "o próprio cearense, astucioso e ativo, nobre no trato e honrado no trabalho, chegava como que desconfiado, acudindo ao apelo insistente dos poderes públicos". Por sua vez, supostos "ingratos" que "abandonavam" as plantações em direção aos estabelecimentos fabris não tinham conta o destino que lhe esperava, "vinham sôfregas, atraídas cegamente por um imaginário núcleo centralizador do trabalho fecundo e altamente remuneratório". Neste ponto, destaca-se ausência de uma narrativa que se valha do determinismo racial, tão comum à época, para contrastar o sucesso agrícola do sul com seus trabalhadores brancos e europeus com o "fracasso" das iniciativas locais com mão de obra negra e mestiça.

Nem por isso, A Nova Aurora deixou de assinalar "o golpeamento que a Abolição, sem indenização, fazia cair, penetrantemente sobre os principais fatores da riqueza pública”. Muitos dos confrades de Astolfo Marques na Academia de Letras e seus amigos e conhecidos da Associação Comercial, em que trabalhou por um período, eram parentes, alguns descendentes diretos, quando não personagens históricas ainda vivas do momento retratado. Eram comuns as polêmicas nos jornais envolvendo a mácula de algum antepassado ilustre. Além das exigências de estilo, não espanta o tom analítico e pouco emocional do autor na narrativa de eventos que transformaram radicalmente suas expectativas de vida.

$\mathrm{O}$ escritor fez eco aos círculos intelectuais que freqüentava na crítica feroz ao "apedrejamento do passado", a tentativa desenfreada dos "poucos trabalhadores rurais 
restantes" tentarem se tornar urbanos. "Em vez de hinos patrióticos, cantando a obra dos heróis subidos a imortalidade da História, entoavam loas injustificáveis aos que não haviam merecido o bastante para igualar aqueles, cujos feitos gloriosos a posteridade não poderia obumbrar". O trecho desvela a contradição que do autor enquanto negro e intelectual ao analisar as conseqüências sociais da Abolição. Não resta dúvida de que, para Astolfo, " $a$ emancipação incondicional dos cativos se promulgou solenemente, como o prenúncio grandioso da edificante obra da Regeneração Social." Entretanto, a tensão ideológica é que o mesmo Maranhão imperial da violenta opressão escravista também havia gerado riqueza literária que pode cognominar-lhe Atenas Brasileira devido à pena e atuação política de homens como Gonçalves Dias, João Lisboa, Odorico Mendes Souzândrade, Aluízio Azevedo, e muitos outros intelectuais aos quais toda a geração de literatos maranhenses da primeira república sentia-se espiritualmente ligada. Escusado dizer que boa parte da obra de Astolfo Marques é dedicada à biografia dos homens ilustres da terra.

No romance, o dilema é equacionado na descrição de Marçal Pedreira, dos freqüentadores de Aurora e as reformas porque passava a chácara em fins de 1889. O capitão liberal e abolicionista não integra o grupo dos "arruinados" pela Abolição. Em meio ao colapso econômico, o proprietário da quinta "não cansava de proclamar-se feliz. Para o lar, tinha ele, no futuro, aquela criança que a todos impressionava agradavelmente. Na política, via o seu partido no poder, a dar as Cartas". A personagem reúne em si o melhor de dois mundos. Toda a tradição cultural e intelectual do Maranhão imperial somada a integridade moral para interpretar a transformação política e econômica do país. Por seu turno, os freqüentadores de Aurora não têm qualquer ligação com o decaído mundo das casas-grandes e senzalas. Eles são funcionários de alto, médio e baixo escalão do recente parque fabril de São Luís, os portadores da utopia de progresso assegurada pela modernização do trabalho livre:

De "essencialmente agrícola" que era, com o crédito constante reafirmado, no exterior, máxime
pelo algodão de fibra mais consistente em toda a produção mundial, passava a Província, por
dadivoza e gentil fortuna, a ser Manchester brazileira. E, para comprova-lo, fazia erguer por todos
os seus recantos, numa acariciante epopéa hinária, a chaminé simbólica do trabalho fabril.
E não houve quem se não tentasse diante da regeneração que se badalava em face da nova aurora,
anunciada em castelos pirotecnicos de reinadio efeito [grifos meus] (MARQUES, 1913, p. 31).

Aurora não poderia passar incólume as dádivas da indústria. Nas suas proximidades, no vasto planalto da Gamboa do Mato, iniciou-se a primeira fábrica de construção de tecidos da cidade. A visão da chácara agora incorpora a chegada das grandes caldeiras e máquinas fabricada por empresas estrangeiras como Rogers Sons e Wolverhapton, as centenas de telhas chegadas diretamente de Marselha, o trânsito dos operários pela ponte 
construída para tornar a fábrica mais acessível, além dos vastos salões preparados para abrigar a produção têxtil.

Com o fito de "acompanhar o progresso do bairro onde situada", a chácara sofrerá algumas reformas. Os portões da fachada da casa e do portão principal tinham sido pintados em cores mais atraentes. Na parte interna, "um riquíssimo mobiliário artístico, cor nogueira, vinha substituir, na sala de visitas, as obsoletas peças de esmerado talhe em angico, com adornos de pau setim, que ali ostentavam pesadamente apegadas o seu estilo colonial [grifos meus]" (p. 36). A velha Aurora, os espaços apegados ao estilo colonial e ao cultivo das tradições senhoriais precisavam dar lugar ao novo mundo aberto pela abolição, o único capaz de abrigar a felicidade de "todo um povo de uma cidade que, a diminuta distância da quinta, se entregava a expansão máxima do folguedo, em misto sacrossanto de religião e hosanas á sua história" (p. 45). 


\section{O Crepúsculo das Ilusões}

Todas as dificuldades com a fruição do capítulo primeiro, sua morosidade e prolixidade, caracterizam seu relativo isolamento mediante a estória narrada nas páginas seguintes. A Regeneração Social anuncia desde o título sua feição de contra-dom para com os temas obrigatórios no campo intelectual provinciano. Em cada cena, um naturalismo etnográfico nos bombardeia com descrições da cidade e da paisagem natural, referência a costumes regionais, procissões religiosas que marcaram época e demais traços diacríticos da identidade local. A ênfase fixa no status social das personagens perfaz rapidamente os critérios necessários para justificar o livro enquanto romance histórico. A grande atenção dispensada à decadência da lavoura, chave ideológica dominante para interpretação culta dos significados da abolição, visa a realçar A Nova Aurora como um livro atento a grandes questões de sua época. Enfim, temos um capítulo-propaganda, um texto para crítico ver.

A trama realmente começa em Na Alvorada da República. Os capítulos terceiro e quarto, analisados nesta seção, apenas encerram o argumento já lançado. É certo que as expectativas sociais divergentes que separam os donos do poder da grande maioria afoita por conhecer a cidadania fora anunciada em tintas carregadas, mas é agora que elas irão encenar sua dialética de vida e morte. A alegoria da aurora é retomada logo no título do capítulo para expressar simultaneamente o raiar do novo mundo republicano, bem como os significados ambivalentes da transformação política para o povo.

O texto é dedicado integralmente à narração do fuzilamento de libertos monarquistas em 17 de novembro de 1889. O conflito, ainda carente de análises historiográficas, resultou da tensão entre os republicanos que no dia anterior anunciavam através do jornal $O$ Globo a derrocada do regime imperial e um vultuoso grupo de negros que ameaçavam destruir a sede do periódico e atacar seus dirigentes, pois viam na queda da princesa Isabel uma ameaça à liberdade conquistada com a abolição.

$\mathrm{O}$ trágico incidente às portas da principal folha republicana da capital é um anátema no imaginário político maranhense. Em O Brasil dos Meus Avós (1927), o escritor Viriato Correa, em crônica dedicada ao episódio, lamenta que só na sua terra, "só no Maranhão, justamente na terra de Beckman, justamente no solo em que brotou uma das primeiras revoluções liberais da nossa história, se derramou algum sangue e algumas vidas se perderam em hostilidade á república." Para o autor de Cazuza, o fato é uma mancha 
inglória na história da evolução das idéias progressistas na província que teve na chamada Revolta de Beckman "uma das primeiras revoluções liberais" do Brasil, foi palco da Balaiada, e quando seria pacificamente coroada com a República, um motim monarquista, o único da história nacional, interrompeu por um dia amargo a marcha do progresso.

O conflito comprometia todas as narrativas acerca da evolução do homem brasileiro e integração política do país à civilização moderna proclamadas pela campanha em prol do novo regime. A "morte do povo", justamente o sujeito político que sustenta a legitimidade de um governo republicano, perturba a simbiose simbólica entre a idéia de república e a efetiva democratização das relações sociais. Não é a toa que ainda em 23 de dezembro de 1889, pouco mais de um mês do ocorrido, o poeta republicano Joaquim Souzândrade aconselhava aos cidadãos maranhenses a darem o episódio por esquecido:

Se algumas horas perturbadas demorou-se o dia do Maranhão, não importa - ai estamos todos rejuvenescentes à luz divinal feita ao conjunto de todas as virtudes, à alegria da ordem, à alegria do progresso, à alegria do trabalho, à alegria da honra, à alegria do direito e à benção das leis. E teremos a lei, porque deixamos de ter o rei. (2003 [1889], p. 514)

Para o poeta que viu na república "a aurora que surge espancando as trevas e $o$ espírito do civismo e de equidade, que inspirava, teria associado os libertos às famílias e nunca desorganizaria as vivas indústrias da pátria”, aquele dia não cabe na história. É preciso esquecê-lo. O 17 de novembro é antes a última página do império brasileiro que parte significativa nas origens da República. Para o republicano histórico, as manifestações públicas dos libertos em apoio à política imperial pós-abolição, eram primitivas e retrógradas, demonstravam apenas "que entre os lúcidos umbrais ainda está o negrume da monarquia, do trono sustentado por guardas negras, a refletir mais escravidão e qual se fora uma negra a guardar” (2003 [1889], p. 501). Neste sentido, escravidão, monarquia e participação política dos libertos fazem parte do mesmo "negrume da história". O trabalho histórico da nova memória coletiva, que deve insurgir pela República, é apagar os laços com as "trevas" do passado. Não será, portanto, as horas perturbadas de uma tarde infame capaz de obstruir as sendas do progresso e a benção das leis. A virtude do esquecimento é poder, sem culpa, abrir os olhos para o futuro, as alegrias do direito e do trabalho.

O conselho parece ter sido prontamente atendido. Não existe nos dias de hoje memória pública do 17 de novembro. Mesmo quando ainda em 1895, apenas seis anos após o ocorrido, Dunshee de Abranches, em suas Memórias de Um Histórico, retomou o poder simbólico do evento nas suas críticas aos descaminhos da República, o político avisa tratar-se de "factos que parecem terem ficado esquecidos, mas que eu não me furtarei de recordar aqui 
como curiosidade historica” (1895, p. 218). Portanto, mesmo no final do século XIX, o "massacre" era dado como esquecido. E será ainda no mesmo espírito de revelar uma curiosidade histórica que Viriato Correa se debruça sobre o episódio na crônica Pela Redemtora em 1927. A intenção é afirmar que, mesmo sendo corretos os discursos sobre o caráter pacífico da passagem da Monarquia à República, "sangue anonymo, sem importancia política, sem vulto historico, derramou-se algum naquelles primeiros dias de queda do Império" (1927, p. 131).

As duas narrativas, mencionadas acima, oferecem um vivo contraste àquela desenvolvida em A Nova Aurora, permitindo-nos capturar com mais acuidade a intencionalidade política na escritura da obra. Observemos o texto do escritor Viriato Correa em O Brasil dos Meus Avós: chronicas da historia brasileira. O autor, também negro e maranhense, era amigo pessoal de Astolfo Marques. Ambos iniciaram suas carreiras no grupo Oficina dos Novos, através do qual publicaram suas primeiras coletâneas de contos dedicadas aos costumes e modo de vida da população maranhense. É a profunda afinidade no projeto intelectual dos escritores, que os fez por diversas vezes, trafegar por temas semelhantes e, neste caso, o mesmo episódio histórico. Entretanto, o livro de crônicas de Viriato, publicado no Rio de Janeiro as vésperas da Revolução 1930, já pertence ao conjunto de iniciativas culturais preocupadas em construir uma idéia de nacionalidade brasileira.

O desafio do escritor é explicar porque somente em São Luís houve resistência civil no ato de proclamação da República. Trata-se de "uma página curiosa, ridicula, na sua execução, mas explicável e ingenuamente pura no fundo, essa luta que estalou em minha terra dois dias depois da quéda do throno”. Uma caracterização um tanto quanto ambígua do episódio. Do alto dos anos 1920 parecia ridículo relembrar que um grupo de negros tentou defender a monarquia na periferia do Brasil, sendo que o país inteiro havia acolhido a república e os próprios áulicos estavam a caminho do exílio. Mas também existe ali "pureza" e "ingenuidade":

O Maranhão, entre as terras perras da quadra do captiveiro, foi uma das mais ásperas e mais ferozes. A historia da escravatura maranhense é profundamente comovedora e dolorosamente lancinante. O 13 de Maio foi lá, mais do que em qualquer outra parte, uma data redemptora. Os negros não viram na abolição uma consequencia logica da marcha evolutiva do paiz, mas unicamente um gesto caridoso da princeza Isabel.

A princeza ficou-lhes na memoria e no coração como uma figura paradisiaca, resplendente de poder e de bondade, uma deusa intagivel, vivendo num céo doirado que elles religiosamente conheciam pela denominação de "corte". Para a princeza tudo! Tudo pela princeza! - a alma, a ternura, o coração, o sangue, a vida!

Que ninguem tocasse nella! Que ninguem tentasse arranha-la no seu throno fulgurante de deusa inacessivel!

As proclamações do "Globo", festejando a victoria da Republica, no primeiro momento não lhes entrou na compreensão. Não sabiam a diferença entre o regimen que se inaugurava e o regimen 
que caia. Mas, quando lhes disseram que o advento republicano era a quéda da corôa e que a princeza, por essa queda, ia ficar sem poder, desamparada, sem mais o throno em que elles a tinham erguido com a imaginação e sair do céo luminoso da "côrte", um por um, todos elles, todos os negros emancipados a 13 de maio, sentiram-se subitamente feridos no fundo da alma fetichista (CORRÊA, 1927, p. 133).

Eis como o "ridículo" e a "pureza" se confundem nas volições que impulsionaram o 17 de novembro. Para Viriato Corrêa, o evento é ininteligível sem destacar a violência sui generis da escravidão maranhense. Naquela província, a Abolição fora realmente a redenção de um sofrimento humano sem par. Esta seria a motivação central do profundo apego dos exescravos à filha de D. Pedro II. Além do mais, os negros, completamente alheios ao mundo político, não viram no fim da escravidão uma conseqüência da marcha evolutiva brasileira. A liberdade lhes pareceu uma dádiva da "princesa redentora", verdadeira encarnação da soberania da bondade sobre os males da terra e pela qual eles seriam capazes entregar a própria vida.

$\mathrm{O}$ autor tenta redimir aquelas pessoas de um ato político que considera quase irracional, aludindo aos sofrimentos do passado escravo e a ignorância dos mesmos acerca do sentido da transformação pela qual o país atravessou em 1889. A "alma fetichista" não lhes permitia compreender sequer a diferença entre os regimes políticos em disputa. Na República, eles só poderiam enxergar o opróbrio de um ídolo amado. Viriato Corrêa tenta romancear o juízo negativo de que os negros estavam despreparados para a cidadania, evocando a lealdade dos mesmos para com a princesa como signos da ingenuidade política e grandeza humana.

Nessa versão, a manifestação violenta dos libertos não passa de um gesto último e desesperado de amor e gratidão em defesa da "Redentora". De acordo com o autor, já ao amanhecer de 17 de novembro, ouvia-se pela cidade boatos de que os negros iriam realizar um ataque armado ao jornal $O$ Globo e seu redator-chefe, o republicano Francisco Paula Belfort Duarte. O celebrado advogado e jornalista "devia ser uma dessas creaturas que não temem carêtas. sabendo que ia ter o jornal empastellado corre á redacção e lá fica a espera do assalto.” Estava armado o palco do conflito. Quando o tenente coronel João Luiz Tavares manda o alferes Barros e Vascosellos e Pereira da Costa pedir ao jornalista que por segurança se recolha no quartel do $5^{\circ}$ Batalhão já era tarde. "Grupos de negros armados de revólver e cacete juntavam-se na vizinhança do "Globo", no sovacão da rua Vinte e Oito de Julho, vivando a princeza. A medida, ali, era outra. Era chamar a força para impedir o ataque que começára". Note-se que nesta narrativa a motivação conjuntural do conflito é a tentativa de Paula Duarte de defender seu jornal e a própria vida. Viriato Corrêa é o único cronista do 
episódio a afirmar a presença de armas de fogo entre os negros, bem como o desejo deles em assassinar o tribuno republicano.

De acordo com o escritor, um destacamento de somente onze praças sob o comando do alferes Antonio Raymundo Bello consegue intimidar provisoriamente o pequeno grupo de negros, que dizia impropérios ao vespertino republicano e seu redator. Mas sendo tão minguado o número de soldados, nada impediu que os manifestantes se organizassem nas circunvizinhanças para intentar uma nova investida.

\footnotetext{
E, ao cair da noite, a onda engrossa.

Agora não é mais aquelle punhado de homens de horas atrás, berrando á porta do jornal, aos vivas a princeza e morras á Republica. É uma turba ululante, numerosa, eletrizada, decidida a morrer em defesa da deusa redemptora.

As 7 da noite tinha-se a impressão de que todos os negros da cidade ali estavam conglobados

O commandante da força sabe que vae ser atacado e prepara-se.

São quase sete e meia quando a multidão avança contra a tropa. É um ataque selvagem, a tiros de revólver, a pedradas e cacos de garrafas.

O alferes Bello vem para frente dos seus soldados e procura dominar o povo, falando, clamando, pedindo que a onda se disperse a bem da ordem e em bem das vidas.

Ninguém quer ouvi-lo (1927, p. 136).
}

O autor pinta um quadro de conflito incontornável. A alusão a tiros de revólver, ao tamanho descomunal da multidão frente a apenas onze praças do exército e ainda ao caráter inflexível dos negros ante a tentativa do alferes de negociar uma saída pacífica tenta nos convencer que a força pública não teve outra alternativa senão a da violência. "O alferes se vê abarbado. Atirar contra aquella gente é immolar muitas vidas. E ordena a tropa que atire para o ar. A descarga resôa. Após o primeiro susto a multidão percebe que ninguém foi attingido pelas balas.” O gesto assanha ainda mais a multidão que acredita estar fora de perigo. "E os negros de novo se atiram contra a tropa, mais vivos, mais ousados, mais loucos, convencidos de que a vão exterminar”. O alferes Bello sente-se em perigo, olha para o lado e vê um soldado com a testa arrebentada por uma pedra, outro está com o braço ferido a tiros. Ele não tem escolha: "Fogo! Berra para os seus commandados. Ouve-se a descarga. Negros caem no chão, feridos, aos gritos, gemendo. A turba dispersa-se desenfreadamente pelas ladeiras á riba, aos trambolhões." O saldo é de três manifestantes mortos de um lado e três soldados feridos do outro. Às oito horas da noite está tudo encerrado.

A crônica Pela Redemptora assim como todos os demais capítulos do livro $O$ Brasil dos Meus Avós intenta apresentar ao público aspectos desconhecidos e curiosos da história brasileira. Ao tornar público o esquecido e único "motim monárquico" que houve no país, Viriato Corrêa pretendia oferecer novos conteúdos para uma história integrada do Brasil. O 17 de novembro já não é um acontecimento que remeta, mesmo simbolicamente, a disputas 
políticas concretas entre grupos sociais, mas parte de um passado que nos unifica como brasileiros. O conteúdo político do evento é totalmente esvaziado. Só nos resta depreender do fato a moral universalista e unificadora das "estórias da carochinha": "a pureza das almas rudes que não se esquecem nunca das creaturas que lhes fizeram algum bem.'”

Muito diferente é a versão oferecida por Dunshee de Abranches em 1895. O autor insere o evento numa análise de fôlego sobre o sentido do movimento republicano mediante as profundas desilusões políticas que marcaram a primeira década do novo regime. Por outro lado, são vivas suas incertezas quanto à estabilidade política do país no seu alerta de que " $a$ volta da monarchia, se não é provável, não é impossivel". Assim, as resistências ao governo, mesmo que simbólicas, não são apenas residuais, mas signos de uma política que não consegue criar raízes no imaginário nacional, uma vez que "se no imperio eram uma mania, na Republica, tornaram-se uma verdadeira epidemia as homenagens vivias e posthumas aos grandes homens com sagrações a óleo”. Epidemia que exemplifica a artificialidade dos ideais igualitários nos primeiros anos do governo republicano.

A particularidade e riqueza dessa análise é sua pretensão nacional. $\mathrm{O}$ autor insere o fato vivido na capital maranhense no conjunto das "resistências à República", observadas no norte do país. Abranches faz questão de também mencionar o conflito encetado pela visita do tribuno republicano Silva Jardim e o Conde d’Eu, consorte da Princesa Isabel, a cidade de Salvador no dia 15 de junho de 1889. Ambos desembarcariam do navio Alagoas por volta das nove horas da manhã e tinham recepções e comitivas distintas. Nas palavras do autor:

\footnotetext{
A massa popular, formada na maioria de libertos, precedendo ao luzido prestito dos mais ilustres titulares e mais nobres conselheiros, ex-ministros, senadores e deputados, entre os quaes os mais poderosos luzeiros do actual congresso republicano, saudava anciosa o enviado imperial. Do outro lado, os estudantes com alguns lentes, jornalistas e homens de lettras, erguiam vivas ao famoso propagandista.

O resultado, portanto, não se fez esperar. Deu-se um conflito inevitavel, e Silva Jardim só pôde fallar no saguão da Faculdade de Medicina (ABRANCHES, 1895, p. 216-7).
}

O destaque ao episódio como um antecedente do 17 de novembro merece nossa atenção. Neste evento, quem entrou para a história como vítima foram os estudantes de medicina, homens de letras, jornalistas e professores ligados à causa republicana. Quando Silva Jardim desembarcou na ponte da Companhia de Navegação, um grupo de estudantes eufóricos acharam por bem retirar o pavilhão real do navio substituindo-o pelo estandarte do republicano. Foi a gota d'água. Uma turba de vaias e agressões capitaneada, nos termos de Silva Jardim, por "capadócios, ferozes homens de cor", desfez a passeata republicana que seguiria pela ladeira do Taboão até a Faculdade de Medicina da Bahia obrigando, sob ameaça 
de morte, alguns dos principais organizadores da comitiva republicana e o próprio tribuno radical a se esconder entre negros e africanos no cais até o clima se acalmar ${ }^{31}$.

A atenção de Dunshee Abranches ao acontecimento não é apenas curiosidade gratuita. O chamado "massacre do Taboão" foi um dentre os muitos conflitos utilizados para racializar a disputa política entre monarquistas e republicanos no tumultuado ano de 1889.

A historiadora Wlamyra R. de Albuquerque anota que o fato foi retratado pela imprensa como um conflito entre civilização e barbárie, uma ação de pretos monarquistas contra republicanos brancos de boa família. O jornal Diário do Povo conjecturou inclusive a existência de uma "luta contra brancos", arquitetada pela coroa e levada a cabo pela Guarda Negra, movimento de libertos destinado a assegurar os direitos e a participação política dos homens de cor no pós-abolição (2009, p. 148). A estratégia discursiva era depreciar a família imperial, dando ênfase à adoração dos negros pelas majestades reais e o perigo que isso representava para os interesses econômicos dos agricultores.

Ao rememorar a presença "dos mais ilustres titulares e mais nobres conselheiros, ex-ministros, senadores e deputados, entre os quaes os mais poderosos luzeiros do actual congresso republicano" na recepção do Conde d’Eu e ataque aos republicanos históricos, Abranches ultrapassa a interpretação exclusivamente racial do incidente. Ou melhor, demonstra que embora seja flagrante a racialização dos interesses políticos ali em jogo, o "massacre do taboão" revela a fragilidade das bases sociais da política republicana, fato que explica boa parte de suas desilusões na última década do século.

O 17 novembro é analisado sob esse mesmo prisma. O autor destaca que, na terra das palmeiras, malgrado o vultuoso número de escravos e a quase inexistência de uma campanha republicana na capital, cultivava-se com ardor "as idéas de liberdade, de justiça e verdadeira fraternidade, parecendo que a alma de Gonçalves Dias vivia em todas as almas, levando-lhes aquelle horror pela opressão e aquelle fetchismo pelo torrão natal." Por outro lado, se não havia muitos adeptos da república, não se encontravam, nas ruas e praças, dísticos que recordassem os feitos da dinastia reinante. Mesmo a visita do Conde d’Eu a São Luís foi friamente recebida pelo povo com direito a uma claque de vaias dos estudantes do Liceu Maranhense. Em suma: a província nortista estava tão preparada quanto qualquer outra para abraçar as benesses da modernização política.

\footnotetext{
${ }^{31}$ Para uma análise detalhada acerca do episódio, consultar o capítulo III de ALBUQUERQUE, Wlamyra R. $O$ Jogo da Dissimulação. São Paulo: Companhia das Letras, 2009.
} 
Desta feita, os problemas ocorridos se deviam a razões conjunturais. Quando o presidente da província Tito A. Pereira de Mattos, parente do Sr Visconde de Ouro Preto foi informado da proclamação da República, delegou ao comandante do Exército que garantisse a ordem e pusesse em prática as decisões emitidas da corte. Entretanto, o militar, "pouco entendido de politica e de administração, hesitou, e nestas hesitações foi deixando correr o tempo, sem que ninguém ousasse a assumir o governo. " Os resultados foram dois longos dias de governo acéfalo. "A propria força de linha via-se entre dous fogos, pois que de um lado o marechal Hermes, da Bahia, exhortava-a que ficasse fiel ás instituições juradas, e do outro o general Deodoro ordenava ao comandante das tropas que assumisse o governo.” Era como se tudo concorresse para um inevitável desfecho com a população liberta, cuja lei áurea, nas palavras do autor, despertara uma sincera dedicação à princesa redentora.

Diante de taes hesitações não havia outra sahida. Os libertos sahiram para as ruas, desconhecendo
o que se passava no resto da nação, sem governo que os esclarecese, sem policia que os contivesse,
elles eram grandes magotes, espalhavam-se por toda a cidade, saudando a remdemptora e á
monarchia.
Mas eram manifestações pacificas, e se haviam gritos sediciosos, os populares não praticaram uma
só violencia, não atacaram ninguem. Apenas na base de uma ladeira muito ingreme em que se
levantava o edificio da redação do Globo, jornal a que attribuiam idéas republicanas, é que elles
faziam maior estádio, vaiando ou insultando os redatores e ameaçando-os com gestos vehementes.
Foi em uma dessas occasiões, em que uma multidão compacta ahi vociferava, que um contigente
de força de linha, não sei se solicitada para manter a ordem, ou por qualquer outro motivo,
descarregou do alto da ladeira sobre toda essa gente desarmada as suas Combalains, não podendo
deixar de causar em tão immenso alvo algumas mortes e numerosos ferimentos (ABRANCHES,
1895, p. 220-1).

A narrativa oferece um contraste flagrante com a versão oferecida por Viriato Corrêa. O nome de Paula Duarte, pivô do conflito em Pela Redemptora e personagem histórica de relevo em A Nova Aurora, não é sequer mencionado. Para Abranches, se os libertos foram às ruas, isso se deve bem mais à incapacidade do governo para esclarecê-los do que se passava no resto da nação que por sua devoção a princesa Isabel. Além do mais, tratava-se de manifestações pacíficas. Mesmo o protesto em frente ao jornal $O$ Globo no qual é afirmado que os ânimos muitoestavam exaltados, não é citada a presença de armas de fogo entre os manifestantes nem se alude a qualquer ferimento grave no destacamento do $5^{\circ}$ Batalhão, antes ou depois de ser efetuada a descarga de tiros contra o povo. O ato é qualificado como uma mistura de ordem arbitrária e covardia para alvejar uma população desarmada, que, sem qualquer chance, dispersou-se em desespero. Ainda assim, após o ataque dos oficiais, um homem ficou de pé entre os mortos e feridos:

Era o que levava a bandeira do Império. Era um negro; e ao ver os soldados que desciam em perseguição dos fugidos, arrancou-a da haste e enrolando-se nella, já coberto de ferimentos, com uma voz forte e resoluta bradou: 


\begin{abstract}
"Viva a princeza redemptora, viva a monarchia!"
Intimado a entregar-se, resistio. Ferido de novo coberto de coronhadas, elle foi rolando pela ladeira abaixo, sempre envolto no seu pavilhão querido e já na extremidade da descida, quasi exhalando o último suspiro, ainda teve forças erguer-se a meio e gritar:

"Viva a remptora!"

E assim morreu aquelle heroe obscuro, sagrado pelo fanatismo de seu ideal e de sua immensa gratidão princeza Isabel, emquanto por toda parte os grandes homens que se notabilisaram a sombra do throno, cheios de honra e de distincções, batiam palmas ao sol nascente e emquanto, na propria côrte os áulicos fugiam das praias, tapando o nariz, para que não se envenenassem com as exhalações putridas do "esquife imperial" (ABRANCHES, 1895, p. 221-2).
\end{abstract}

Um romantismo sincero e comovido transborda da pena de Abranches. Nem sequer sua menção a uma testemunha ocular que lhe assegurou a veracidade destes fatos nos impede de perceber suas modulações literárias e efeitos de retórica. O narrador nos dá um herói. É como se todo o sentido do 17 de novembro encontrasse sua morada no gesto suicida desse homem obscuro. Ferido a balas de comblain, o negro enrola-se na bandeira imperial e dá vivas à redentora e à monarquia. Poderia ter se entregado mas resistiu e dedicou o último suspiro ao "fanatismo de seu ideal" a sua "imensa gratidão" pela princesa Isabel. Paradoxalmente, enquanto isso, os antigos nobres preparam-se para obter seus postos de poder na República e as majestades reais fugiam para o seu exílio na Europa.

A montagem da cena heróica é um ataque veemente à fragilidade das bases sociais da política republicana. O autor lembra que toda aquela cena se deu "em um estado longínquo, onde parecia que o imperio não medrara raízes". Portanto, a dúvida que fica é como o tumultuado contexto pós-governo Floriano Peixoto, o pouco espaço dos políticos civis nos governos republicanos além da presença poderosa de ex-monarquistas na nova configuração política, seria capaz de conferir ao novo regime a estabilidade necessária para consolidar o poder republicano. Por outro lado, mediante a artificialidade dos valores de cidadania, talvez a única coisa que simbolize a transformação política seja, paradoxalmente, um mártir negro suicidando-se por uma causa derrotada.

Em A Nova Aurora o 17 de novembro não é apenas uma anedota curiosa e ridícula do nosso passado histórico e não integra uma disputa pessoal pelo poder. A crítica politica se dirige aos significados culturais da transformação social. O conflito como um instante primordial da modernidade brasileira. É o contrato social entre o novo Estado e o povo que está em questão. De modo ainda mais denso, indaga-se sobre quais as alternativas culturais que uma sociedade egressa da escravidão possui para dar legitimidade à cidadania, legitimidade ao princípio de que todos os homens são iguais entre si. Talvez por isso não haja lugar para heróis no livro. Todas as personagens ficcionais ou históricas encenam seu papel, 
vulgar ou elevado, na trama de uma identidade histórica que nos condiciona e já nos pertence. Não sem razão, quem rouba a cena aqui é o povo:

Ao largo do Carmo, certo o local onde maior era a aglomeração, iam ter a toda hora mensageiros de diretores imaginários ou incógnitos da rebelião decidida. Era o meeting, por convite anônimo, que se ia realizar ali, aonde havia convertido o centro das operações. Parecia que todos os homens que, no ano anterior, estavam delirantes pela extinção do elememento servil, se achavam congregados na praça, formando uma guarda avançada ao trono em que desejariam ver Izabel, a Redentora, pois visando a este bendito nome, de propósito, era os vivas que soltavam ininterruptamente, num entusiasmo eletrizante, e em convicção profunda de baterem-se por um ideal que não compreendiam com absoluta nitidez [grifos meus] (MARQUES, 1913, p. 53-54).

Aí estão os personagens de ação no romance, aqueles que no ano anterior encheram os corações de esperança com o advento da Abolição. A descrição valoriza os signos doloridos e silenciosos do passado escravo, inversamente representados na "exultação" e "delírio" dos negros nas festas de 13 de maio, bem como na "convicção profunda de baterem-se por um ideal que não compreendiam com absoluta nitidez”, o monárquico. O protesto no Largo do Carmo é majoritariamente composto pelos "estivadores do Jeronymo Tavares, trabalhadores das companhias das Sacas (Prensa) e União (Tesouro), operários da Usina do Rapozo, embarcadiços, catraeiros e pescadores das praias do Cajú e do Desterro" (p. 55). Até o fim do livro, o Capitão Marçal Pedreira e os freqüentadores de sua chácara serão ouvintes ou narradores do que se passa na vida política desses homens. Essa estrutura ficcional permite que o autor consiga transferir, não sem desequilíbrios, a centralidade narrativa do mundo elitista de Aurora para o povo.

O 17 de novembro é o centro dessa "política secreta" na estrutura da obra. Astolfo Marques faz do evento um instante privilegiado para narrar as origens da moderna sociedade brasileira do ponto de vista dos ex-escravos. Ao tomar as páginas centrais do romance, um povo continuamente desumanizado faz-se senhor do próprio destino. A própria imagem do autor - um garoto liberto de 13 anos de idade quando da proclamação da república pesquisando meticulosamente acontecimentos esquecidos da história negra de sua terra é a metalinguagem viva desse mesmo movimento de libertação, capaz de fraturar o imaginário social racializado acerca dos sentidos da vida intelectual. Contra o pano de fundo da memória coletiva e pessoal do tempo do cativeiro e a vivência cotidiana do racismo, a experiência e os significados da "criatividade artística", "liberdade de pensamento" e o "papel da literatura" ganham contorno políticos contraculturais específicos na expressão estética negra pósemancipação, particularmente visíveis na elaboração de marcadores temporais alternativos às narrativas dominantes da evolução nacional. Essa problemática é especialmente relevante para investigação da cultura intelectual na diáspora africana: 
Os escritores [negros], particularmente os mais próximos da experiência escrava, repudiavam a narrativa heróica da civilização ocidental e adotavam uma abordagem filosófica da escravidão a fim de minar o tempo monumental que a sustenta. Quaisquer que sejam seus desacordos sobre a teleologia da emancipação negra, Du Bois, Douglass, Wright e os demais compartilhavam a percepção de que o mundo moderno estava fragmentado ao longo de eixos constituídos pelo conflito racial e poderia acomodar modos de vida social assíncronos e heterogêneos em estreita proximidade. Suas concepções de modernidade eram diferentemente periodizadas. (...). Eram pontuadas por processos de aculturação e terror que acompanharam essa catástrofe e pelas aspirações contraculturais rumo a liberdade, cidadania e autonomia, que se desenvolviam depois dela entre os escravos e seus descendentes (GILROY, 2001, p. 368).

A narração do 17 novembro, como temporalidade ética distintiva para repensar o nascimento da política republicana, insere A Nova Aurora no corpus crítico da diáspora africana. É significativo que, em The Souls of Black Folk (1905), escrito apenas sete anos antes do romance aqui analisado, o sociólogo afro-americano W. E. B Du Bois (1868-1963) também lance mão da alegoria da aurora para expressar os significados ambivalentes da modernidade para os povos de $\operatorname{cor}^{32}$.

No capítulo Sobre o Significado do Progresso o autor narra sua experiência como mestre-escola nas colinas do Tenessee. Os dois verões nos quais exerceu esse ofício o aproximaram de uma pequena comunidade de agricultores negros muito pobres, que lá viviam em pequenas choupanas isoladas e casas de fazenda. O jovem professor se afeiçoou a muitas daquelas pessoas de rostos que iam do "creme pálido ao marrom escuro", pois eram dotadas de "uma certa gentileza, um heroísmo moral inconsciente que de bom grado daria toda a vida para torná-la maior, mais profunda e mais plena para si e para os seus”. Os estudos o afastaram por dez anos do alto da colina e, quando a saudade o fez voltar, sua escolinha de madeira não existia mais. "Em seu lugar erguia-se Progresso; e o Progresso, segundo entendi, é necessariamente feio". Morte, prisão, miséria e racismo haviam moldado irrevogavelmente a face do futuro.

As crianças de pés descalços e empoeirados que se alegraram com a chegada da escola já eram homens e mulheres feitos. Muitos foram para cidade tentar sobreviver, Jim foi preso acusado de roubar trigo, a inteligente Josie trabalhara muito duro e morreu com depressão, Thenie também se foi após uma longa caminhada para escapar das surras do marido, Ben, que felizmente era um ativo fazendeiro, quase foi linchado por lutar com um branco que lhe negou o pagamento. De volta a Nashville, num vagão segregado, Du Bois interroga-se:

\footnotetext{
${ }^{32}$ Para aprender, de modo mais completo, o sentido da alegoria da aurora em Du Bois ver o capítulo Sobre a Aurora da Liberdade em The Souls of Black Folk.
} 
Como é possível medir o progresso lá onde jaz a escura Josie? Quantos corações dilacerados custarão o preço de um alqueire de trigo? Que coisa difícil é a vida para os humildes e, no entanto, como é humana e real! E toda essa vida, e esse amor, e a luta e fracasso - tudo isso será o crepúsculo que anuncia a noite, ou o rubor de um dia de pálida aurora? [grifos meus] (DU BOIS, 1999, p. 129-30).

Ao confrontar a idéia de progresso com o sofrimento negro, com uma luta e um amor que não consegue sustentar a vida, o autor rasura a narrativa heróica da civilização ocidental com tempo fragmentário de uma subjetividade cindida entre a experiência diferenciada do terror racial e a expectativa moral cosmopolita de tornar a humanidade maior e mais profunda. Utopia que só é possível se a crítica social dos significados da modernidade for capaz de começar no espaço ético onde jaz a escura Josie, onde o preço do alqueire de trigo custa corações dilacerados, ou mesmo no entardecer de uma pequena e distante província do norte brasileiro, onde negros foram fuzilados lutando contra o temor de voltarem a ser escravos.

Com efeito, a presença e força imaginativa da alegoria da aurora em Du Bois e Astolfo Marques é uma coincidência não arbitrária. Não apenas por suas raízes culturais românticas e abolicionistas semelhantes, mas especialmente por permitir figurar, em claro e escuro, as incertezas políticas do mundo moderno para aqueles que precisam enfrentar a memória recente do passado escravo, a estranha ambigüidade de ser, a um só tempo, negro e ocidental. Nos termos do sociólogo afro-americano, o desafio intelectual proposto em A Nova Aurora é justamente como "medir o progresso" dos novos tempos republicanos na periferia do Brasil através do "medo da escravidão", que banhou de sangue a ladeira do viramundo.

Observe-se que Na Alvorada da República já inicia com o clima tenso na cidade devido ao anúncio da queda da monarquia e uma descrição enaltecedora da campanha republicana. O caráter historiográfico do texto revela-se devido a ausência de personagens ficcionais enquanto ocorre a recuperação de figuras históricas. $\mathrm{O}$ autor reproduz literalmente a curta notícia veiculada no dia 16 de novembro pelo vespertino $O$ Globo em letras garrafais: "República Proclamada. Ministério Preso. Exército e Povo Confraternizados. Viva a República!”. O vespertino que deu manchete ao escândalo político "era órgão da dissidência do partido liberal; e, se bem que de circulação, não muito remota, vinha de certa forma trabalhando simpaticamente pela causa republicana local, até com restrito número de adeptos. O seu principal redator e Dr. Pedro Belarte” (p. 46). Na verdade, o mesmo Paula Duarte, que conhecemos no texto de Viriato Corrêa é, retratado aqui como um "tribuno 
eloqüente, eletrizador das massas populares, nos meetings, e empolgador dos auditórios, pelos lances felicíssimos e boutades oratórias, com sua palavra burilada e quente” (p. 46).

Astolfo Marques não esconde a admiração pelo "republicano histórico" da capital maranhense, embora saibamos que Paula Duarte só aderiu a causa nos começos de 1889 (ABRANCHES 1993, MEIRELES 1994). Ele surge no romance como o retrato das benesses políticas da civilização moderna, "insinuante, de porte fidalgo e irrivalizável pela elegância, parecia-se com o então Príncipe de Galles (...). O vestuário, o andar, as atitudes, assinalavam-lhe o espírito altamente superior e culto” (p. 46). Neste perfil, a representação do ser intelectual ancora-se na corporalidade branca, o vestuário e a elegância digna de um príncipe inglês sinaliza a presença de um espírito superior e culto. Não é a toa que Humberto de Campos fazia troça do orgulho que o escritor negro possuía ao "exibir, pondo em destaque o seu terno de casimira azul-marinho, cuidadosamente passado a ferro, os mais duros e lustrosos colarinhos do Maranhão", ninguém lhe esqueceria sua "tez escura e embaciada" e a "beiçorra da raça" (CAMPOS, 1957, p. 71-2). Bem mais do que a visão profundamente racializada e hierárquica da atividade intelectual na época, a descrição de Paula Duarte carrega a tensão subjetiva do autor para articular o lugar social de seu corpo e suas aspirações ao reconhecimento literário.

Por outro lado, a figura do doutor "Pedro Belarte" também simboliza a relação da província com a produção cultural que circulava nas seletas instituições de ensino superior no país à data do romance. Eis a importância de destacar sua formação na Faculdade de Direito de São Paulo e o "tirocínio acadêmico memorável”, que demonstrara em periódicos universitários como A Razão, no qual fazia par com Campos Sales, ninguém menos que terceiro presidente do Brasil republicano. A intenção é demonstrar que o Estado não estava alheio ao movimento de renovação política nacional:

No interior, lá na região sertaneja, o movimento se desenrolara vívido, marchava sublimemente,
sem peias, intransigente. De cidade em cidade, de vila em vila, ia em uma ramificação que
impressionava os monarquistas. Em Barra do Corda, a chave do sertão, Izaac Martins faria circular
um semanário, órgão das idéias republicanas, e fundava-se um clube democrático. Na cidade de
Carolina, formava-se também um clube republicano; e, na Imperatriz, as urnas com estupefante
surpresa, deram votos a Benjamim Constant e a Quintino Bocayuva, para deputado geral, contra o
candidato situacionista (MARQUES, 1913, p. 51).

A objetividade da descrição impressiona. As análises históricas contemporâneas sobre a implantação do regime republicano no Maranhão têm destacado, cada vez mais, a centralidade da região sertaneja nesse processo ${ }^{33}$. Entretanto, aqui, o "real” é mais um artifício

\footnotetext{
${ }^{33}$ Alberto Ferreira, ao analisar as condições sociais de emergência do movimento republicano no Maranhão,
} 
ilusório da literatura com intencionalidades que não se esgotam na finalidade exclusiva do registro histórico. O desenvolvimento "sublime" da bandeira da igualdade pelos sertões maranhenses, com total autonomia ideológica da capital, construindo alianças fortes diretamente com a corte, coaduna com o argumento da vocação inerente da "terra" para regeneração social, para aurora da cidadania. No mesmo sentido, Pedro Belarte festeja a proclamação da república dizendo: "Este grande povo fornece a civilização um grande testemunho. Nem uma gota de sangue, nem a mais tênue alteração da ordem pública. Em nome da liberdade, em nome da democracia, em nome da humanidade sejamos calmos generosos e grandes” (p. 50). No dia seguinte, cada uma dessas palavras seria testada.

Durante toda manhã, informações desencontradas sobre a mudança do governo espalharam-se por São Luís. “A proporção que o dia se adiantava nas horas, o movimento era mais crescente por todas as ruas, já não sendo segredo que se tramava de uma resistência belicosa a qualquer ordem que por ventura viesse do centro para os republicanos assumirem o governo” (p. 52). O Largo do Carmo lotou de gente disposta a defender a princesa Isabel, e com ela, os direitos adquiridos na abolição. "O sol de um dia ardente dardejava aquela onda humana (...). Havia gente, havia chefe de arruaça. Apenas faltava uma cabeça pensante ou um braço forte para intemeratamente dirigir o movimento a estalar” (p. 55). Um boletim convidando o povo para a conferência de saudação à República por Paula Duarte deu aos manifestantes hora e local do protesto.

Como que por encanto trepou ao mais alto dos degraus do Pelourinho, secularmente erguido no largo, um crioulo bem corpulento e invejavelmente robusto, charuto ao canto da boca, deixando espelhar-se pelo semblante o que de entusiástico lhe ia na alma. Com a mão direita o rapaz brandia sua bengala canela de veado e, na outra, empunhava, atado a uma vara tortuosa, o auriverde pavilhão com a coroa da monarquia derrocada (MARQUES, 1913, p. 56-7).

A imagem é expressiva. O jogo sutil intentado pela narrativa é obrigar o leitor, presumivelmente branco, a atravessar o semblante revoltado de um crioulo para decifrar-lhe a

destaca que: "os sertanejos reivindicavam maior atenção dos governantes, mas estes priorizavam as regiões agroexportadoras objetivando equilibrar as finanças da província. Por outro lado, as constantes trocas de presidentes devem ter contribuído para que algumas solicitações não fossem atendidas. O certo é que o Alto Sertão pouco se beneficiou das medidas modernizadoras (navegação a vapor, estradas, engenho central, fábricas têxteis) implementadas na província na segunda metade do século XIX. Nesse contexto, foi o sertão um campo propício para a germinação das idéias republicanas. Seus partidários conheciam os modelos de República implementados na França e nos Estados. Porém, sua motivação maior era o federalismo, a busca de autonomia, como uma maneira de reação à hegemonia política da parte norte da província (FERREIRA, 2004, p. 214). Por seu turno, o historiador Mario Meireles, analisando os eventos citados por Astolfo Marques, esclarece que: "atuando com plena autonomia e desconhecendo o que estaria no mesmo sentido se passando na capital da Província, o Clube de Barra do Corda, além de disposto a apelar para a luta armada, comprometeu-se espontaneamente com Quintino Bocaiúva, a fazê-lo Deputado Geral pelo $6^{\circ}$ Distrito Eleitoral do Maranhão, para que o Partido Republicano tivesse a seu serviço no Parlamento, a força de sua voz e de seu prestígio. Por fim, decidiria que o próprio Isaac Martins [presidente do clube] viajasse para o sul, a se entender com os grandes próceres nacionais do movimento" (MEIRELES, 1994, p. 104). 
alma. Só é possível capturar o sentido crítico da descrição, se por um instante, tentarmos enxergar o mundo do mais alto degrau do pelourinho, da memória pública e secular o suplício negro. Soma à beleza do excerto, o detalhe precioso de relatar que, junto ao pavilhão da coroa, erguia-se a vista de todos, o charuto no canto da boca e a bengala canela de veado, costumes da população negra de São Luís.

Os manifestantes seguiram por "bairros estreitos e íngremes" e a multidão crescia cada vez mais. Foi em vão que, na rua do Sol, quando o protesto estancou à frente do palacete do conselheiro presidente da Província para lhe render homenagens, este, "todo ungido dum sentimento de clemência e cordura, aconselhava aos exaltados a paz, a voltar ao lar, para junto dos entes queridos, e, em muito insinuante lucidez, apelava já para os fatos consumados". Muito ao contrário do que fizera o monarquista liberal João Eduardo no retorno dos revoltosos ao Largo do Carmo, quando incitou a multidão contra as palavras do presidente, num discurso que "fizera tocar ao auge o delírio dos defensores da monarquia, empolgando-os todos, tornando decididos pouquíssimos porventura vacilantes e como curiosos adstritos ao movimento” (p. 62). Logo depois saiu de cena deixando para trás uma multidão incendiada.

Nesse ponto, é nítida a tentativa de Astolfo Marques em re-interpretar o 17 de novembro. $\mathrm{O}$ autor é o único dentre os cronistas conhecidos a dar destaque e suma importância à participação dos monarquistas liberais brancos no protesto. Fato que lhe permite uma interpretação mais complexa da relação entre raça e política expressa na revolta. A historiografia oficial republicana, nas poucas linhas que dedica ao episódio, institucionalizou a versão de que não fosse a idéia irracional do perigo da re-escravização, corrente entre os negros, nada de grave teria lhes acontecido no fim daquela tarde. No livro História do Maranhão: manual para os alunos da escola normal (1904), o advogado e pedagogo Barbosa de Godóis (1860-1923) afirma que "feita a abstração de um grupo de libertos pela lei de 13 de maio que, imbuídos pela idéia grosseira de que a República viera para reduzi-los novamente ao cativeiro (...), nenhuma outra manifestação em contrário a nova instituição surgiu em toda a província”"(p. 359). Desta feita, a manifestação negra fora isolada, injustificável e politicamente sem qualquer sentido.

O diálogo crítico de Astolfo Marques com a primeira História do Maranhão me parece ser direto uma vez que Barbosa de Godóis era figura importante e confrade do romancista na Academia Maranhense de Letras. No ano retratado pelo romance, o advogado era redator-chefe do jornal A Pacotilha, folha de maior circulação na cidade; ele também compôs a letra do Hino Maranhense e foi o terceiro vice-governador do Maranhão 
republicano. O manual para os alunos da escola normal fora a única fonte com vistas à história geral da região durante toda a República Velha. Assim, a "moral da história” ensinou, por gerações sucessivas de estudantes, que a eclosão do conflito na alvorada da república foi provocada pelas "idéias grosseiras dos libertos"; no fundo, os negros foram mortos e feridos por sua própria ignorância. Pouco mais de cinqüenta anos depois, afirmava-se que:

A única anormalidade ocorrida foi uma manifestação de escravos, recentemente libertos, contra
Paula Duarte, o único republicano no novo governo, e isso porque se dizia que o novo regime
vinha para tornar sem efeito a Lei Áurea. Indo os manifestante contra a redação de $O$ Globo, o seu
jornal, a polícia interferiu imediatamente, dispersando-os, isto na véspera da adesão. Mas a
circunstância de, na boca do povo, ter ocorrido tal incidente, aliás sem maior gravidade, como se
houvera sido um massacre - os fuzilamentos do dia 17, dizia-se - concorreu para um ambiente de
frieza, indiferença e desconfiança, contra a República [grifos meus] (MEIRELES, [1960] 2001, p.
269).

O trecho supracitado pertence ao livro História do Maranhão escrito por Mário Martins Meireles, sendo publicado originalmente em 1960 e dedicado as duas primeiras turmas de bacharéis e licenciados da Faculdade de São Luís (1956, 1957). Aclamada em mais duas edições ampliadas $(1981,2001)$ e citação obrigatória nos estudos contemporâneos da área, trata-se da mais prestigiada obra da historiografia maranhense do século XX. O trabalho pretendia tão somente, nas palavras do autor, preencher as lacunas históricas dos velhos manuais escolares, dos trabalhos memorialísticos, das biografias de políticos ilustres e dos compêndios coloniais - na época, as únicas fontes para estudo histórico da região. No entanto, a obra tornou-se um dos primeiros enforços em história regional a conquistar para si o status de estudo científico.

Neste sentido, o texto acima oferece a versão científica dominante quanto ao 17 de novembro. É digno de nota que o autor escreva "manifestação de escravos" no sentido de "manifestação de negros". Não há qualquer menção ao uso da violência no incidente, ao contrário, os fatos se desenrolaram "sem maior gravidade" e a interferência da polícia apenas "dispersou" os manifestantes. De acordo com o historiador, a idéia de "massacre" e o boato dos "fuzilamentos" são exageros da mente popular sem o respaldo dos dados, uma "fofoca" que só serviu para criar um ambiente de hostilidade contra a República - a verdadeira vítima do episódio.

A Nova Aurora regia contra a institucionalização deste senso comum douto. Talvez justamente devido à pena do escritor negro objetivar no romance o modo como o inconsciente coletivo popular, no seu caso, também pessoal, registrou o fato histórico. Entretanto, ao tornar-se texto, a versão da história transmitida pela "boca do povo" transforma seu registro cultural originário, revestindo-se de autoridade intelectual. Neste sentido, o 
empreendimento de Astolfo Marques era bem mais ambicioso do que aparenta a primeira vista, tencionava consolidar seu status de pesquisador dos fatos da terra - anote-se que o livro as Festas Populares Maranhenses: narrativa histórica é anunciado na contracapa do romance - atacando interpretações dominantes com insights originais e visão política abrangente e sofisticada.

A grande dificuldade do autor, neste capítulo fulcral, é como deslocar a interpretação do 17 de novembro de um "problema de libertos", "uma anormalidade", para um evento capaz de fazer pensar os sentidos da transformação política nacional como um todo. A valorização do discurso de um monarquista liberal branco questiona o consenso sobre as "idéias grosseiras dos libertos" e socializa o sentido cultural e político do conflito para toda a sociedade maranhense. Para o autor, "aquele povo, aparentemente reivindicador e idólatra, seguia a sem serenidade reflexiva, impelido pela sugestão de emocionais argumentos" (p. 63, grifos meus). Ou seja, para que o protesto se dirigisse violentamente até as portas da redação $O$ Globo, razões conjunturais, como a irresponsabilidade de políticos aproveitadores e o entusiasmo pouco reflexivo das multidões, somaram-se às incertezas dos ex-escravos quanto a seu destino político. Munidos de "porretes de madeira indígena", "pedras", "matacões", "pedaços de canos enferrujados", os revoltosos não se intimidaram ao assistir a marcha do $5^{\circ}$ Batalhão seguindo para dar guarida à folha republicana.

\footnotetext{
A onda ganhava terreno, e a tropa seria, na certa, dizimada a pau e pedra... Nisto o oficial, medindo rápido a situação, ordenou uma descarga para o ar, em intimidação última.

Ao estrondar os tiros a vozeria aplaca, para surgirem as imprecações, sob novas e mais decisivas arremetidas. Outra descarga, agora certeira a multidão apupante. Os soldados falhavam a previsão dos intemeratos irmãos atacantes, pois a disciplina mandava obedecer incontinente, disparando as espingardas para rechaçar o povo, cujo grosso já recuava em debandada infrene.

Três ou quatro dos assaltantes, inclusive o crioulo porta-bandeira, caem instantaneamente. Dezenas de feridos, uns graves, rolando nas pedras da ladeira, aos gritos lancinantes, outros levemente praguejando, clamavam por socorro, que não chegava [grifos meus] (MARQUES, 1913, p. 64-5).
}

Desespero, dor, abandono e morte são as palavras que assaltam a mente do leitor no desfecho de Na Alvorada da República. Nesta narrativa, o 17 de novembro, à semelhança da análise política de Dunshee de Abranches, fora realmente um massacre. Uma interpretação polêmica, considerando-se as narrativas canônicas da historiografia regional que menosprezam o sentido político do incidente.

No entanto, um estudo recente sobre o caso, influenciado sobremaneira por $A$ Nova Aurora, conferiu a Astolfo Marques a autoridade científica reivindicada pelo seu caráter historiográfico. O historiador Alberto Ferreira, seguindo as pistas do escritor negro, reúne dados para comprovar a ocorrência de um verdadeiro massacre. Ao consultar as baixas de 
pacientes no hospital da Santa Casa da Misericórdia após o conflito, o autor assinala que “observando-se os ferimentos recebidos pelos manifestantes (mais de 400 pessoas), pode-se inferir que os soldados atiraram para matar, pois nove dos quatorze feridos ou mortos foram alvejados na parte superior do corpo" (2004: 226). A geografia local, também prova, de acordo com o historiador, a intenção de matar, na ação do exército, pois os oficiais se posicionaram estrategicamente no cruzamento das ruas Nazaré e 28 de julho, atirando nos manifestantes que subiam esta última, sem qualquer chance para as vítimas ${ }^{34}$.

Esta análise é importante, não apenas por nos esclarecer com mais objetividade o ainda nebuloso 17 de novembro, mas também por revelar os sentidos contemporâneos da recepção intelectual de Astolfo Marques. Malgrado os "cuidados hermenêuticos" da ciência histórica contemporânea no tratamento das fontes e análise de obras artísticas, o romancista aparece, quando citado, como uma alternativa de "fidelidade" ao mundo social em que viveu. Tal como a crítica negativa do autor que ficou para a posteridade, valoriza-se o "observador meticuloso e sem imaginação" sem que possamos flagrar em seus escritos o processo de criação cultural.

Paradoxalmente, a própria "idéia de massacre" apresentada em A Nova Aurora só é plenamente inteligível se relativizarmos o seu realismo imediato. Através dela, enfatiza-se a singularidade do caráter violento da passagem do regime monárquico para o republicano no Maranhão. A tese da "terra excepcional" apresentada no primeiro capítulo é retomada em nova chave. Em meio a um país "bestializado", o povo maranhense, mesmo que num protesto condenável, não se furtou à participação política. Deste modo, "sob o batismo lustral do sangue do povo, [passa] o Maranhão á historia como a unica província heróica que, dentre as vinte opuzera tenaz rezistencia, pelas armas, ao derruimento súbito da nobre dinastia” (p. 66 , grifos meus). O 17 de novembro, ao invés de ameaçar a identidade regional, assinalandolhe as marcas dos "fetichismos da mente popular" como em Viriato Corrêa, confere à data um lugar único e heróico na história brasileira.

Este aspecto fica mais saliente quando notamos que na narrativa o "massacre" é descrito ao mesmo tempo como um "batismo" e um "fatricídio" - observe-se o uso do termo “irmãos” na descrição do conflito. Nesse sentido, mais do que um fato histórico, o massacre

\footnotetext{
${ }^{34} \mathrm{Na}$ trilha de Astolfo Marques, contrariando as versões historiográficas que minimizam o impacto do célebre episódio, o historiador afirma: "Foi, pois, devido a repressão violenta aos ex-escravos no célebre episódio de 17 de novembro que as manifestações de adesão ao regime demoraram alguns dias para acontecer. Os estudantes do Liceu, um dos centros de idéias republicanas da capital maranhense, emudeceram e só organizaram a primeira passeata pró República no dia 22 de novembro. Para a população como um todo era preciso ter certeza de que o governo não iria agir com o restante da sociedade como agira com o populacho por ocasião do meetting de 17 de novembro" (FERREIRA, 2004, p. 226).
} 
na ladeira do viramundo é pensado como o rito sacrificial de origem do novo mundo republicano ${ }^{35}$. Um evento que condensa, em sua violência primeva e batismal, toda a ontologia social da comunidade recém-nascida. A "morte do povo" é a imagem fundante que desvela os significados políticos do progresso na periferia nacional. O 17 de novembro tornase, por seu caráter único e singular, o instante primordial da modernidade brasileira.

Dito isto, peço atenção do leitor para a representação do massacre como um "fatricídio". A imagem radicaliza a problemática que perseguiu toda a geração de intelectuais brasileiros da República Velha: a ausência de uma identidade coletiva, capaz de se enraizar no imaginário social, através do sentimento de pertencer a uma cultura comum nacional e o reconhecimento legal da igualdade de direitos entre os cidadãos ${ }^{36}$. Talvez aqui resida o sentido político de todo o trabalho etnográfico de Astolfo Marques, qual seja, a busca dos elos culturais que permitam concretizar essa utopia moderna numa sociedade dividida pela herança civil da escravidão. O 17 de novembro, enquanto um "massacre entre irmãos", assinala que o desafio democrático da república é expiar o pecado original de sua identidade.

Só a partir deste ângulo muito específico que o autor nos apresenta intricada relação entre raça e política "na alvorada da república". O mote é a descrição do atendimento hospitalar aos manifestantes feridos no protesto. Mais uma vez o clima é de muita tensão. A Praça da Caridade, em frente ao Hospital da Santa Casa, está lotada de gente ainda sem notícia da sorte dos parentes ali internados em estado grave. Lá dentro, o grande número de feridos tornou a sala de operações o palco de uma verdadeira carnificina. Pacientes tinham seus membros imediatamente amputados sem qualquer cuidado prévio. "Tratava-se era de acelerar a operação, desprezando-se um exame mais detido, uma pesquisa mais minuciosa, a comprovar se todos os feridos necessitavam, efetivamente, de intervenção cirúrgica” (p. 76).

\footnotetext{
${ }^{35} \mathrm{~A}$ ritualização do massacre pode ser melhor observada, destacando o caráter quase sagrado que o autor transmite ao acontecimento. Imediatamente após o combate fatricida, em meio ao silêncio dos mortos e desespero dos feridos: "Na igreja, ainda a sinarada cantava sonora na torre. E, na sua tristeza latejante, parecia o dobre do De Profundis pelos que acabavam de baquear, a pouca distância do templo, lamentavelmente vitimados pelo apego a insensatez" (MARQUES, 1913, p. 65).

36 Ao analisar os impasses para a realização das premissas políticas republicanas no contexto brasileiro, o historiador José Murilo de Carvalho afirma que: "A dificuldade brasileira com os dois modelos de liberdade, a dos antigos e a dos modernos, estava talvez na ausência de um elemento que tais modelos não levavam em conta, mas que era na realidade parte importante, ou mesmo uma premissa, para o funcionamento deles. Para que funcionasse a república antiga, para os cidadãos aceitassem a liberdade pública em troca da liberdade individual; para que funcionasse a república moderna, para que os cidadãos renunciassem em boa parte à influência sobre os negócios públicos em favor da liberdade individual - para isso, talvez fosse necessário a existência anterior de um sentimento de comunidade, de identidade coletiva, que antigamente podia ser o de pertencer a uma cidade e que modernamente é o de pertencer a uma nação. (...). A busca de uma identidade coletiva para o país, de uma base para construção da nação, seria uma tarefa que iria perseguir a geração intelectual da Primeira República (1889-1930). Tratava-se, na realidade, de uma das bases para a redefinição da República, para o estabelecimento de um governo republicano que não fosse uma caricatura de si mesmo. Porque foi geral o desencanto com a obra de 1889 (CARVALHO, 1990, p. 32-3).
} 
Um processo de mutilação massivo que revoltou o barbeiro Macedo, chamado ao local, para auxiliar os enfermeiros e médicos com aplicações de sangue-sugas.

Condoía-se a alma do deitador de bichas ante aquele enervante vibrar do serrote decepador; e tanto si lhe revoltou a consciência quando, para terminar depressa, não se detiveram mais os instrumentos cortantes, que ele, esquecendo a sua posição subalterna, ali, não se conteve e deixou escapar corajosamente a censura que lhe pairava aos lábios: julgava verdadeira falta de humanismo aquele preparo que se lhe evidenciava de atirar-se a cidade cerca de duas dezenas de aleijados, o que, pela própria cirurgia, ali em ação, poderia ser evitado. E concluiu afirmando temerariamente ser aquilo que se estava a praticar uma verdadeira carnificina, uma barbaridade sem nome.

O,dr. Firmiano, chefe do serviço hospitalar pasmou diante da afoiteza do barbeiro, em tão melindroso momento. Suspendeu o serrote e, encarando-o, atônito, e firmemente, disse-lhe, em tom imperioso: - Olá, meu petulante, isto aqui não é açougue, onde a gente da tua laia rejeita os ossos! Faze apenas o teu serviço e não te atrevas a meter bedelho aonde não se te chamou. Quem se imiscui em coisas de brancos, tem a mesma tristíssima sorte aqui destes de teus companheiros, seu refinado patife! - E sabe que mais? Rua! [grifos meus] (MARQUES, 1913, p. 76-7).

Nas ações e no pensamento do barbeiro Macedo, encontramos a crítica negra aos limites da modernidade republicana. A relação íntima entre a transformação política de 1889 , supostamente civilizadora, e a desumanidade social do racismo. Mais ainda: o modo como as "mutilações" da cidadania são mediadas por hierarquias opressivas, que conjugam uma relação de saber/poder. É a autoridade científica que detém legitimidade para a um só tempo sujeitar os saberes populares sobre a saúde e converter o corpo negro em objeto de suplício.

Note-se que a posição subalterna do barbeiro Macedo é inicialmente qualificada pelos conhecimentos que o mesmo agencia. Ele é apenas um "deitador de bichas" em meio a pessoas dotadas do conhecimento científico, um mero "freqüentador de açougues" nas palavras do Dr. Firmiano. O conflito entre ambos quanto aos procedimentos médicos espelha também o confronto entre os saberes tradicionais e o científico numa sociedade em processo de modernização. Ao levantar a voz contra as arbitrariedades dos doutores, o barbeiro questionava a suposta relação entre ciência e evolução social. Nos instantes tumultuados vivenciados ali na Santa Casa o barbeiro fez-se portador do humanismo civilizador enquanto o doutor era agente do terror bárbaro. $\mathrm{O}$ autor inverte as concepções doutas que conectam as tradições populares iletradas à barbárie enquanto representa homens de ciência e seus conhecimentos como a vanguarda do progresso humano. Não apenas devido à crença na eficácia relativa dos conhecimentos tradicionais, mas porque esses saberes estão enraizados numa experiência social comum capaz de dar a homens divididos por mais de três séculos de escravidão o sentimento de pertencimento de uns aos outros, aquelas disposições emocionais que permitem ao barbeiro se revoltar contra a violência e a desumanização de um outro visto, através da cultura, como um "igual". 
O humanismo crítico que move a escrita de A Nova Aurora atinge sua plena complexidade nas palavras repulsivas do Dr. Firmiano, instante em que o amálgama entre raça e política é exposto cruelmente: "Quem se imiscui em coisas de brancos tem a mesma tristíssima sorte destes teus companheiros, seu refinado patife!” Tanto o saber científico quanto a esfera pública são representados como "coisas de brancos". O autor flagra a falência das utopias de "regeneração social" abertas pela Lei Áurea no instante em que os aparatos técnicos e científicos modernos conduzem a clivagem racial dos significados da transformação política republicana. A carnificina na sala de operações da Santa Casa é a expressão micro-política desta tendência autoritária convertida em ordem social pelo governo provisório. 


\section{Considerações Finais}

As investigações desenvolvidas nesta dissertação são um estudo exploratório de um projeto de pesquisa mais amplo, a ser desenvolvido a longo prazo, intitulado Negros de Atenas: intelectuais negros maranhenses na formação do Brasil moderno (1870-1930). Esta proposta de trabalho consiste na análise da vida e obra de quatro destacados intelectuais maranhenses no período considerado. Por ordem de nascimento: Hemetério José dos Santos (1858-1939), Raul Astolfo Marques (1876-1918), José do Nascimento Moraes (1882-1958) e Viriato Corrêa (1884-1967).

O objetivo geral da pesquisa é compreender de que modo as origens étnico-raciais desses autores determinaram suas possibilidades de reconhecimento intelectual, assim como suas criações estéticas no período em que a população egressa da escravidão se tornou um sujeito político relevante para a formação da moderna sociedade brasileira, que se consolidou na chamada Primeira República (1889-1930). O estudo integrado desses homens permite compreender também de que modo ocorreu a inserção do negro nas institucionais tradicionais da vida intelectual brasileira como a grande imprensa, as instituições políticas, organizações partidárias e as academias de letras.

Nesse quadro, Raul Astolfo Marques é um exemplo complexo. Dentre todos os intelectuais negros selecionados para o projeto, o autor destaca-se por apresentar uma história de vida em que não se flagra de imediato qualquer capital cultural que o habilite as posições sociais que o consagraram. Negro, pobre, servente, autodidata, ou seja, haja "imaginação sociológica" para entender como um preto faxineiro se torna um intelectual respeitado na Primeira República.

Entretanto, a partir das pesquisas nos periódicos e jornais, conseguimos detectar o modo como o autor, "pela porta dos fundos", formou uma extensa rede de relações sociais junto às elites dirigentes locais. Isto porque as condições da crise econômica e a inexistência de um projeto coerente de "organização da cultura" no trabalho de dominação tornaram a Biblioteca Pública de São Luís, seu lugar de trabalho, uma instituição fundamental para sociabilidade e desenvolvimento do movimento cultural ludovicense, A Oficina dos Novos, mais eficaz na primeira década do século XX.

Esse grupo literário é a chave para compreender as estratégias do próprio Astolfo Marques em sua carreira. A Oficina constituiu parte significativa do handcap do jovem Raul 
para a consolidação da vida profissional no funcionalismo público e sua futura incorporação à Academia Maranhense de Letras, a saber, a instituição que preserva a memória do autor até os dias de hoje.

O trabalho de Secretário-Geral da Oficina, além de inseri-lo nos periódicos literários mais duradouros do momento, lhe conferiu um controle prático de todo o programa intelectual de sua geração. Ele fazia os relatórios, marcava reuniões, enviava notas aos jornais, se comunicava com intelectuais maranhenses prestigiados no campo literário nacional, além de publicar seus próprios trabalhos. Por outro lado, o autor desenvolveu um projeto intelectual afinado com as "necessidades simbólicas" das elites. Não sem razão, a Seleta Maranhense, livro dedicado ao ilustres da terra, é o trabalho de melhor recepção no seu meio. Astolfo se apoderava das condições simbólicas de legitimação intelectual das oligarquias maranhense. $\mathrm{O}$ fato desse trabalho, mesmo que perdido, seja o de maior destaque nos principais necrológicos do autor confirma essa consideração.

$\mathrm{O}$ aspecto mais surpreendente da trajetória intelectual de Astolfo Marques é que sua obra literária pode ser lida como uma crítica das condições sociais instaladas no Maranhão após a proclamação da República, as mesmas que subsidiaram sua própria ascensão social. $O$ autor forjou sua crítica nos seio das relações paternalistas que o sustentavam, através dos códigos estéticos e políticos que constituíam a linguagem dominante. A Nova Aurora, embora escrita num momento de maior estabilidade profissional, não é exceção à regra. A aparente contradição entre o seu republicanismo e as tristezas advindas das consequiências políticas imediatas do novo regime para o povo marca a ambivalência de um exercício crítico que emerge das aspirações de um negro pobre por melhores condições de vida, todavia, condicionadas e expressas por uma linguagem filtrada na razão de sua própria opressão. 


\section{Bibliografia Geral}

ABRANCHES, Dunshee de (1895). Memórias de Um Histórico. Tip. Official do Jornal do Brasil.

. (1993) A Esfinge do Grajaú. São Luis: ALUMAR.

ALVES, Uelinton Farias (2009). José do Patrocínio: a imorredoura cor do bronze. Rio de Janeiro: Garamond.

ALBUQUERQUE, Walmira R. de (2009). O Jogo da Dissimulação. São Paulo: Companhia das Letras.

ALENCASTRO, Luiz Felipe de (2000). Trato dos viventes: formação do Brasil no Atlântico Sul. São Paulo: Companhia das Letras.

ALMEIDA, Alfredo Wagner Berno de (2008). A Ideologia da Decadência. Rio de Janeiro: Casa 8. 2a . Edição.

AZEVEDO, Elciene (2005) Orfeu de Carapinha. São Paulo: Editora Unicamp.

BARBOSA DE GODÓIS, Antonio Batista (2008) História do Maranhão. São Luís: AML/EDUEMA.

BARBOSA, Francisco de Assis (1988). A Vida de Lima Barreto. São Paulo: Editora Itatiaia Limitada/Universidade de São Paulo.

BARRETO, Lima (2001). Prosa Seleta. Rio de Janeiro: Editora Nova Aguilar.

BORRALHO, José Henrique de Paula (2009). A Athenas Equinocial: a fundação de um Maranhão no Império Brasileiro. Rio de Janeiro.

(2000) Terra e céu de Nostalgia: tradição e identidade em São Luís do Maranhão. UNESP/ São Paulo.

BOURDIEU, Pierre.(2001) Campo do Poder, Campo Intelectual e Habitus de Classe. São Paulo: Ed. Perspectiva.

.(1998) A ilusão biográfica. In: FERREIRA, M e AMADO, J. Usos e

Abusos da História Oral. Rio de Janeiro: FGV.

CAMPOS, Humberto (1957). Memórias Inacabadas. São Paulo: W. M. JACKSON INC Ed.

CANDIDO, Antonio (2006). Literatura e Sociedade. Rio de Janeiro: Ouro sobre azul. $9^{a}$.Edição.

(2004). O Discurso e a Cidade. Rio de Janeiro: Ouro sobre Azul, São

Paulo: Duas Cidades.

CARVALHO, Alfredo (ORG) (1908). Expozição Commemorativa do Primeiro Centenário da Imprensa Periodica Brazileira In: Revista do Instituto Historico e Geographico Brazileiro. Rio de Janeiro: Imprensa Nacional. 
CARVAlHO, José Murilo de (2005). A Formação das Almas. São Paulo. Companhia das Letras.

(1998). Os Bestializados. São Paulo: Companhia das Letras.

CARVALHO, Maria Alice Rezende de (2009). “André Rebouças a questão da liberdade”. In O Brasil (não) é para Principiantes. SCHWARCZ e BOTELHO(Orgs). São Paulo, Companhia das Letras.

(2008). "Intelectuais Negros en el Brasil Del SigloXIX”. In: História de los intelectuais en América Latina. ALTAMIRAUS, Carlos (Director) Vol. 1. Buenos Aires, Kata Editores.

(1998). Quinto Século. Rio de Janeiro. Editora Revan; IUPERJ/UCAM.

CHALHOUB, Sidney (1990). Visões da Liberdade. São Paulo. Companhia da Letras.

CORRÊA, Viriato (1927). O Brasil dos Meus Avós. São Paulo: Ed. Nacional.

COSTA, Emilia Viotti da (1998). Da Monarquia à República. São Paulo. Ed. UNESP.

DAIBERT JUNIOR, Robert (2004). Isabel: a “redentora" dos escravos. São Paulo. EDUSC/FAPESP.

VIEIRA FILHO, Domingos (1982). Populário Maranhense (Bibliografia). São Luís: SIOGE.

DOMINGUES, Petrônio (2006). “O 'Messias' Negro? Arlindo Veiga dos Santos (1902-1978)

In Varia História. Vol. 22, n.36 p. 517-536. Jul/Dez.

DU BOIS, W. E. B.(1999) As Almas das Gentes Negras. Rio de Janeiro: Lacerda Ed..

FRAGA FILHO, Walter(2006). Encruzilhadas da Liberdade. Campinas: Ed. Unicamp.

FILHO, Domingos Vieira. (1977). Folclore Brasileiro.Rio de Janeiro: FUNART..

(1954). Astolfo Marques e a Associação Comercial In: Boletim da Associação Comercial do Maranhão.

(1951). Os Escritores Maranhenses In: Revista do Maranhão\ Vol I,

FASC VI. São Luís.

GILROY, Paul. O Atlântico negro (2001). São Paulo Ed. 34, Rio de Janeiro: Universidade Candido Mendes, Centro de Estudos Asiáticos.

GOMES, Flávio.(2005) Negros e Política. Rio de Janeiro: Zahar.

(1991). "No meio das águas turvas (Racismo e cidadania no alvorecer da República: a Guarda Negra na Corte - 1888-1889”. In Estudos Afro-Asiáticos, n.21. Rio de Janeiro. Candido Mendes.

GRAMSCI, Antonio.(1979) Os Intelectuais e a organização da Cultura. Rio de Janeiro: Civilização Brasileira.

GUIMARÃES, Antonio Sérgio Alfredo.(2004) Intelectuais negros e formas de integração 
nacional. Estud. av, vol.18, no.50.

(2004). "Manoel Querino e a formação do pensamento negro no Brasil, entre 1980 e 1920”. Caxambu: ANPOCS.

LACROIX, Maria de Lourdes Lauande (2002). A Fundação Francesa de São Luis e seus mitos. São Luis: Lithograf. $2^{\mathrm{a}}$.Ed.

LEAL, Maria das Graças de Andrade (2004). Manuel Querino: entre letras e luta. São Paulo. Tese de doutorado-PUC.

LOBO, Antonio (2008) Os Novos Atenienses. São Luis: Academia Maranhense de Letras/Editora UEMA.

LOPES, Antonio (1959). História da Imprensa no Maranhão (1821-1925). Rio de Janeiro:

Departamento de Imprensa Nacional.

LOPES, Nei (2007). Dicionário Literário Afro-Brasileiro. Rio de Janeiro: Pallas.

LUZ, Joaquim Vieira (1954). Dusnshee de Abranches e Outras Figuras. Rio de Janeiro: Edição do autor.

MARQUES, Astolfo. (1913) A Nova Aurora. São Luis: Tipografia Teixeira.

(1916). “Os Reis Republicanos". In O Jornal, 24 de Dezembro.

Maranhão.

(1908). Natal. São Luis: Tipogravura Teixeira.

MARQUES, Astolfo.(1909) O Dr. Luiz Domingues. São Luis: Tipografia Teixeira. . (1903). “A última Sessão”. In Os Novos. São Luis.

MARTINS, Manuel de Jesus Barros(2006). Operários da Saudade. São Luis: EDUFMA.

MEIRELES, Mário. História do Maranhão. São Paulo: Siciliano, 2001.

Dez Estudos Históricos. São Luís: ALUMAR, 1994.

MICELI, Sérgio.(2001) Intelectuais à Brasileira. São Paulo: Companhia das Letras.

MONTELLO, Josué.(1994) Diário da Noite Iluminada. (1993). Janela de Mirante. São Luis: Sioge.

(1975) Tambores de São Luis.

MORAES, Jomar(1977). Apontamentos de Literatura Maranhense. São Luís: Sioge.

PATROCÌNIO, José (1996). Campanha Abolicionista: coletânia de artigos/José do Patrocínio. Rio de Janeiro, Fundação Biblioteca Nacional.

PAXECO, Fran(1919). Astolfo Marques In: Revista da Academia Maranhense de Letras. São Luís: Imprensa Oficial.

RAMOS, Clóvis. Nosso Céu Tem Mais Estrelas: 140 anos de literatura maranhense. Rio de Janeiro: Pongetti, 1973. 
REID, Andrews (1998). Negros e Brancos em São Paulo, 1998-1988. São Paulo. EDUSC.

REIS, João José (1995). “Quilombos e revoltas escravas no Brasil” In Revista USP. São Paulo. N. 28, Dez/fev, pp.14-39.

SCHWARCZ, Lilia Moritz (2004). As Barbas do Imperador. São Paulo. Companhia das Letras. (1993) O Espetáculo das Raças. São Paulo: Ed. Companhia das Letras.

SOUZÂNDRADE, Joaquim. Poesia e Prosa Reunidas de Souzândrade/ Organização: Frederick G. Willians e Jomar Moraes. São Luis: Edições AML, 2003.

VENTURA, Roberto (1996). “Euclides da Cunha e a República” In Estudos Avançados 10 (26). p.275-291.

VIVEIROS, Jerônimo de (1960). Benedito Leite: um verdadeiro republicano. São Luis, Academia Maranhense de Letras/Instituto Histórico e Geográfico do Maranhão.

(1954). História do Comércio do Maranhão. São Luís: ACM.

\section{PERIÓDICOS CONSULTADOS:}

\section{Jornais/Revistas}

A Ateneida (1912)

A Pacotilha 1900-1918 ()

Diário do Maranhão (1900-1910)

O Federalista (1900-1905)

O Jornal (1915-1918)

Os novos (1900-1904)

Revista da Associação Comercial do Maranhão (1908 - 1910)

Revista do Norte (1900 - 1906)

Revista Maranhense de Cultura (1917 - 1918) 
Bibliografia de Raul Astolfo Marques identificada nesta pesquisa

\subsection{Livros}

MARQUES, Astolfo (1908) Natal. São Luis: Tipografia Teixeira.

MARQUES, Astolfo (1909) O Dr. Luiz Domingues. São Luis: Tipografia Teixeira.

MARQUES, Astolfo (1913) A Nova Aurora. São Luis: Tipografia Teixeira.

MARQUES, Astolfo (1905) Vida Maranhense. São Luis: Tipografia Teixeira.

\section{0 - Artigos (contos, crônicas e ensaios)}

\section{A Pacotilha (1900-1918)}

1o. de maio de 1903 - O Socialismo entre nós ( Crônica/artigo)

13 de novembro de 1903 - A Procissão do Redentor (conto)

01o de janeiro de 1904 - A Opinião da Euzébia (conto)

06 de fevereiro de 1904 - A Discussão das Firminas (conto)

08 de março de 1904 - O Socialista (conto)

09 de abril de 1904 - O Fundador (Crônica)

03 de maio de 1904 - Os dois herdeiros (conto)

26 de novembro de 1904- O Vinho do Núncio (conto)

24 de dezembro de 1904 - Presépio do Nicolau (conto)

22 de abril de 1905 -Vestido de Judas (conto)

13 de maio de 1905 - Ser treze (conto)

10 de novembro de 1906 -Os Socialistas Alemães e o Congresso de Manheim (Flavio Reimar)

13 de dezembro de 1906 - Novos Horizontes - (Flavio Reimar)

25 de novembro de 1906 - O Natal do Rufino (conto)

2 de Março de 1908 - De Corôa e Barrete (conto)

20 de julho de 1908 - A Cartola do Geraldo (conto)

4 de dezembro de 1908 - Em Paz (conto)

25 de dezembro de 1908 - Presentes de Festas (conto) 
05 de janeiro de 1910 - A Escola Profissional (artigo)

20 de janeiro de 1912 - As Nossas Habitações (artigo)

20 de janeiro de 1917 - As Exportações Maranhenses (artigo)

\section{Diário Oficial (1911-1912):}

25 de outubro de 1911- A Conservação do Porto (artigo)

3 de janeiro de 1912 - As Nossas Habitações (artigo)

8 de janeiro de 1912 - A Comemoração de Reis (artigo)

3 e 14 de fevereiro - A Defesa Agrícola publicado (artigo)

8, 14 e 20 de março de 1912 - Quaresmais (artigo)

\section{O Jornal (1915-1918)}

7 de Janeiro de 1915: Artistas Guerreiros (artigo)

19 de janeiro de 1915: Casamentos Gorados (conto)

15 de fevereiro de 1915: Entrudo e Penitência (conto)

17 de fevereiro de 1915: O Carnaval nas Ruas(conto)

19 de Março de 1915: Quaresmais: a procissão da cana-verde (estudo histórico)

26 de Março de1915: Quaresmais: a procissão dos navegantes (estudo histórico)

22 de junho de 1915: Deserção do Noitante

01 de julho de 1915: As Fogueiras do Consolação

16 de Julho de 1915 : O Brasil Social (resenha)

3 de Março de 1916: Os Crimes do Hipnotismo

29 de junho de 1916 : As Fogueiras do Consolação

14, 23, 30 e 31 de agosto de 1916: Comentários (coluna de Astolfo Marques)

11, 14, 20 de setembro de 1916: Comentários (coluna de Astolfo Marques)

13, 14, 15 e 25 de outubro de 1916: Comentários (coluna de Astolfo Marques)

20 de dezembro de 1916: Comentários (coluna de Astolfo Marques)

24 de Dezembro de 1916: Reis Republicanos (conto)

2 de janeiro de 1917: Presentes de Festa (conto)

24 dia janeiro de 1917: Comentários (Conto) 


\section{Diário do Maranhão (1901 - 1910)}

10 12, 14, 19, 23 e 27 de dezembro de 1901 Odorico Mendes: apuntos biográficos.

4, 9, 10,11,12,13,14,15,16,17, 18, 20, 21, 22, 23, 25, 27, 29, 30 e 31 de agosto de 1906

De S. Luiz a Therezina (Notas de viagem)

1, 3, 5, 6 e 7 de Setembro de 1906 - De S. Luiz a Therezina (Notas de viagem)

5 de janeiro de 1910 - O Natal de 1908 (crônica etnográfico)

24 de março de 1910 - O Sermão do Encontro ( crônica etnográfico)

2, 4 e 5 de abril de 1910 - A Festa de São Benedito (história etnográfica)

Revista da Associação Comercial do Maranhão ( 1908 - 1910)

Novembro de 1908 - O Comércio do Maranhão

Julho de 1910 - Novo Rumo

\subsection{Traduções:}

\section{0 - Jornal A Pacotilha}

23 de julho; 173, p.2. “A princeza da Harpa d'Oiro" (Maurice Gandolphe ) - Conto

24 de julho; no 174; pág. 2: “A Princeza da Harpa d'Oiro” (Maurice Gandolphe) - Conto

25 de julho; nº175; pág.2 e 3: A Princeza da Harpa d'Oiro" (Maurice andolphe) - Conto

26 de julho; nº 176; pág. 3: A Princeza da Harpa d'Oiro" (Maurice Gandolphe) - Conto

27 de julho; n 177; pág. 3: “A Princeza da Harpa d'Oiro”(Maurice Gandolphe) - Conto

28 de julho;n 178; pág. 3: “A Princeza da Harpa d'Oiro" (Maurice Gandolphe) - Conto

30 de julho; nº 179; pág. 3: A Princeza da Harpa d'Oiro" ( Maurice Gandolphe) - Conto

18 de agosto; n 196; pág. 2: “ O casamento da Hermancia” (Albert Gim) - Novela

20 de agosto; n 197; pág. 2: “O casamento da Hermancia” (Albert Gim) - Novela

21 de agosto; n 198; pág. 2: “O casamento da Hermancia” (Albert Gim) - Novela

22 de agosto; n 199; pág. 2: “O casamento da Hermancia” (Albert Gim) - Novela

23 de agosto; n 200; pág. 3: “O casamento da Hermancia” (Albert Gim) - Novela 
24 de agosto; n 201; pág. 3: “O casamento da Hermancia” (Albert Gim) - Novela 27 de agosto; n 203; pág. 3: “O casamento da Hermancia” (Albert Gim) - Novela 28 de agosto; n 204; pág. 3: “O casamento da Hermancia” (Albert Gim) - Novela 29 de agosto; n 205; pág. 3: “O casamento da Hermancia” (Albert Gim) - Novela 19 de setembro; $\mathrm{n}^{\circ}$ 223, página 2: “A princeza muda” : (Pierre Mille) - Conto 20 de setembro; $n^{\circ}$ 224, página 3: “A princeza muda" (Pierre Mille) - Conto 21 de setembro; n 225, página 2: “A princeza muda” (Pierre Mille) - Conto 22 de setembro; $n^{\circ} 226$, página 3: “A princeza muda” (Pierre Mille) - Conto 24 de setembro; $\mathrm{n}^{\circ}$ 227, página 3: “A princeza muda” (Pierre Mille) - Conto 25 de setembro; $\mathrm{n}^{\circ}$ 228, página 3: “A princeza muda” (Pierre Mille) - Conto 26 de setembro; $n^{\circ}$ 229, página 2 e 3: “A princeza muda” (Pierre Mille) - Conto 24 de dezembro; nº 304, página 2 e 3: "O mensageiro Divino” (André Mevil)-Conto

\section{1 - Jornal A Pacotilha}

01 de janeiro; no1; pág. 2: “O Anno- Bom”:( Fernand Fau)- Conto. 04 de janeiro; n 4; pág. 2: "Os três Reis": (Emile Gebhart) - Conto 05 de janeiro; no 5; pág. 2 e 3: "Os três Reis" (Emile Gebhart) - Conto 07 de janeiro; n 6; pág. 2: "Os três Reis" (Emile Gebhart) - Conto 08 de janeiro; no 7; pág. 3: "Os três Reis” (Emile Gebhart) - Conto

\section{Ano 1902 - Jornal A Pacotilha}

01 de janeiro; $n^{\circ}$ 1; pág.1: “ O palácio de neve- “ conto de Anno Bom” ( Jean Lovrain) 02 de janeiro; nº 2; pág. 1: “O palácio de neve- "Conto de Anno Bom (Jean Lovrain)

\section{Ano 1903 -Jornal A Pacotilha}

25 e dezembro, $\mathrm{n}^{\circ}$ 306; página 01: “Annos Mortos” (Adolphe Brisson) - Conto 


\subsection{Recepção da obra de Astolfo Marques}

- 26 de junho de 1905: A Vida Maranhense In: O Federalista.

- 26 de junho de 1905 : A Vida Maranhense In: A Pacotilha (de Bento Vallares)

- 27 de junho de 1905 : Semanais In Diário do Maranhão (Hernani - pseudônimo)

- 29 de agosto de 1908: Crônica da Roça In A pacotilha (Lincon - Pseudônimo).

- $1^{\circ}$ de dezembro de 1908: Natal de Astolfo Marques (Da Academia Maranhense de Letras) In A Pacotilha.

- 3 de dezembro de 1908 : Natal In A Pacotilha (Angela Grassi)

- 5 de dezembro de 1908: Pela Rama In A Pacotilha (Antonio Lobo)

- 25 de fevereiro de 1909: Livros Novos: Natal, Astolfo Marques (1908) In: Diário do Maranhão.

- 27 de Fevereiro de 1909: Notas - Natal, Astolfo Marques (1908) In: Diário do Maranhão.

- 1o. de Abril de 1909: Bibliografia ( sobre o livro Dr. Luiz Domingues) In: Diário do Maranhão. 
Anexos 
